\title{
DIVERSITY ON ADJUDICATIVE ADMINISTRATIVE TRIBUNALS: AN INTEGRATIVE CONCEPTION
}

by

\section{Sandra Yuko Nishikawa}

A thesis submitted in conformity with the requirements for the degree of LL.M. Graduate Department of the Faculty of Law University of Toronto

(c) Copyright by Sandra Yuko Nishikawa (2009) 
Diversity on Adjudicative Administrative Tribunals: An Integrative Conception

LL.M. 2009

Sandra Yuko Nishikawa

Faculty of Law

University of Toronto

\begin{abstract}
This thesis applies arguments for greater diversity, and more specifically, racial diversity, on the judiciary to administrative tribunals with an adjudicative function. I draw from both formal arguments, such as institutional legitimacy, and substantive arguments, such as the different perspectives that diversity would provide, to propose an integrative conception of diversity. By relying upon concepts such as structural impartiality, I argue that an integrative conception of diversity more fully reveals the transformative potential of diversity in legal decision-making. This integrative conception is particularly well-suited to the administrative context because it demonstrates how diversity will enhance the values of participation and justification, which are instrumental to the principle of fairness. Through interviews with adjudicators and legal clinic lawyers, I offer a preliminary view of the potential impact that diverse administrative adjudicators could have in practice. Finally, this thesis offers recommendations on how this potential could be further realized.
\end{abstract}




\section{ACKNOWLEDGEMENTS}

I would like to take this opportunity to thank all who assisted me at every stage of this project. I am grateful to my thesis supervisor, Professor Audrey Macklin, for her assistance and for her helpful feedback, and to my second reader, Professor Jennifer Nedelsky, who also provided me with invaluable guidance. I also thank Professor Lorne Sossin and Professor Sonia Lawrence of Osgoode Hall Law School for taking the time to provide me with further insight and comments. I appreciate the advice that I received from my S.J.D. advisor, Rommel Salvador.

Needless to say, I am especially grateful to all of the individuals who took time out of their busy schedules to meet with me for the qualitative research component of this thesis. In addition, the topic of this thesis was inspired by a talk given by Dr. Lilian Ma, Chair of the Landlord and Tenant Board of Ontario, and I am indebted to her for directing me to such a fruitful area of research.

A work of this nature is never really the product of one person's efforts. This is especially true when the person has three young children. I received much encouragement from friends, classmates and colleagues, which was much appreciated. I am grateful to my family for doing everything possible to help me complete this thesis: my children, Lucas and Emi, for exhibiting patience and understanding beyond their years; baby Miya (whose first birthday coincided with the completion of this thesis), for her smiles and sleeping skills; my parents, Motoi and Kiyoko, for a lifetime of support and assistance; and my spouse, Vincent, who never tired of discussing my research and reading drafts, for his constant encouragement and support. 


\section{TABLE OF CONTENTS}

CHAPTER I - LEGITIMACY AND PUBLIC CONFIDENCE: THE INSTITUTIONAL RATIONALE

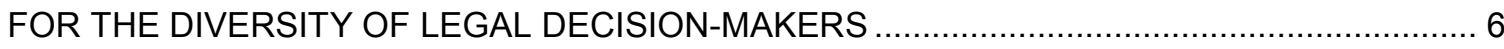

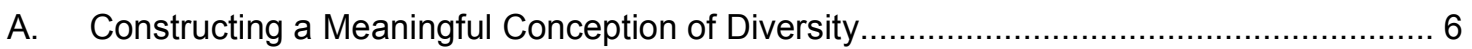

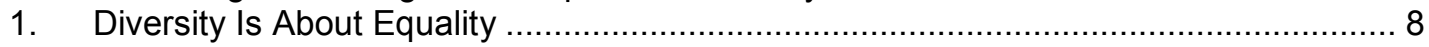

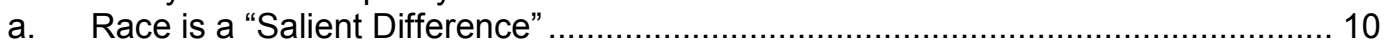

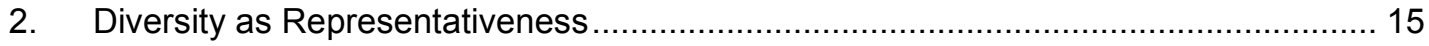

a. The Necessity of Group Representation.......................................................... 18

B. Diversity As Furthering Democratic Legitimacy.................................................. 20

1. A Lack of Diversity Compromises Legitimacy ..................................................... 21

2. Diversity Fosters Public Confidence in the Justice System ..................................... 23

C. The Institutional Rationale for Diversity Applies to Administrative Tribunals ................... 25

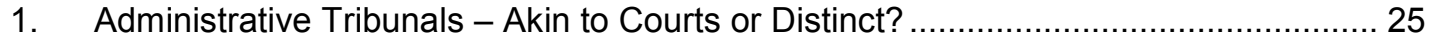

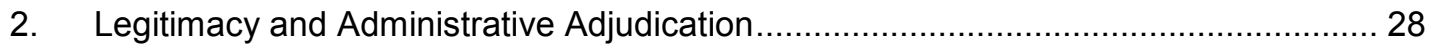

CHAPTER II - EXPERIENCE AND PERSPECTIVE: THE INDIVIDUAL RATIONALE

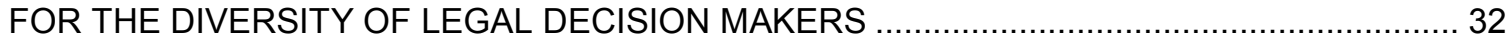

A. Diversity Challenges Traditional Conceptions of Adjudication .................................... 32

1. The Limitations of Traditional Conceptions of The Role of the Judge ........................ 33

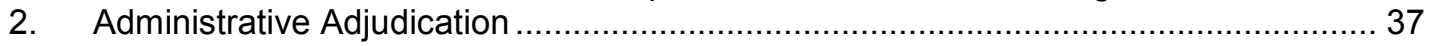

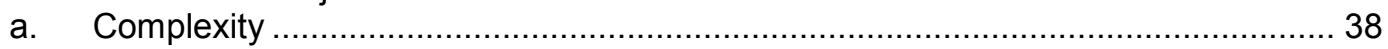

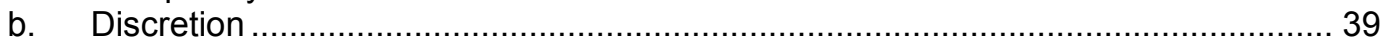

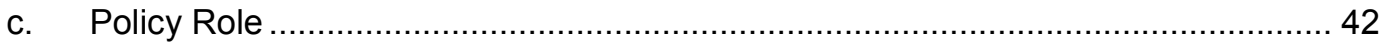

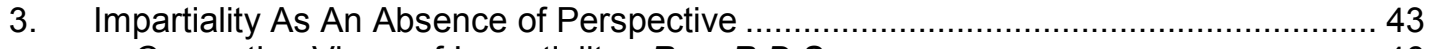

a. $\quad$ Competing Views of Impartiality: R. v. R.D.S. ................................................. 46

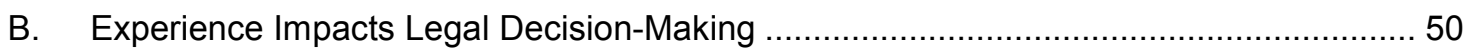

1. The Experience of Marginalization Affects Perspective ........................................... 53

2. Legal Decision-Makers Will Respond Differently to Alternative Narratives ................. 58

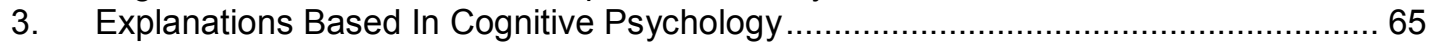

4. Empirical Evidence of the Impact of Diversity on Legal Decision-Making ................... 68

CHAPTER III - STRUCTURAL IMPARTIALITY: AN INTEGRATIVE CONCEPTION

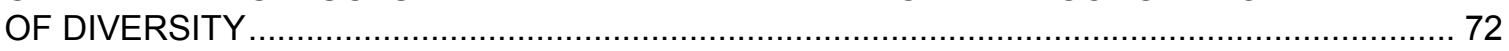

A. Reconceiving Impartiality as Incorporating Multiple Perspectives ................................ 72

1. Judging with an Enlarged Mentality: Arendt's Theory of Judgment.......................... 73

2. Including Multiple Perspectives to Create a "Community of Judgment" ...................... 77

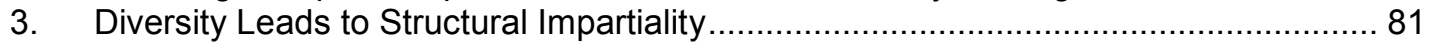

a. The Jury as an Example of Structural Impartiality ................................................ 83

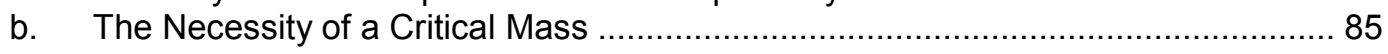

B. An Integrative Conception of Diversity: Diversity Enriches Legal Decision-Making........ 87

1. Administrative Tribunals: An Ideal Setting for an Integrative Conception of Diversity. 88

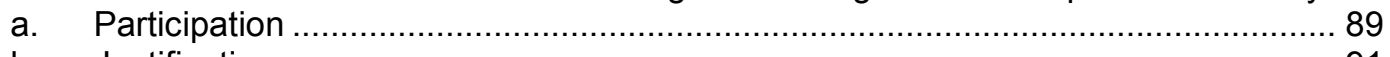

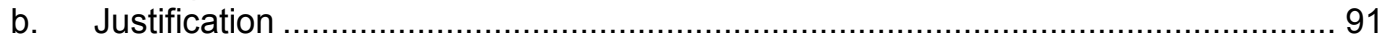




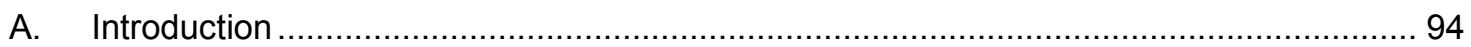

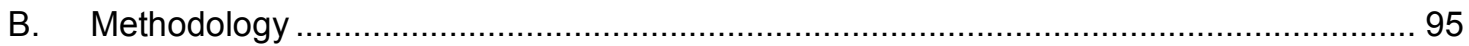

1. Access to Information and Freedom of Information Requests ................................. 95

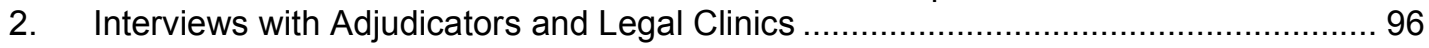

C. Current Representation of Racialized Persons on Administrative Tribunals .................. 99

1. The Representativeness of Federal Tribunals ...................................................... 100

2. The Representativeness of Federal Appointments ............................................. 101

3. The Representativeness of Tribunals in the Province of Ontario ............................ 104

D. The Impact of the Presence of Racially-Diverse Adjudicators .................................. 105

1. The Human Rights Tribunal of Ontario - A Community of Judgment....................... 105

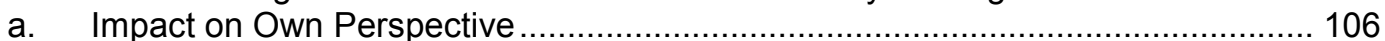

b. Impact on Perspectives of Fellow Adjudicators ................................................. 108

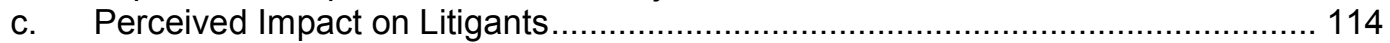

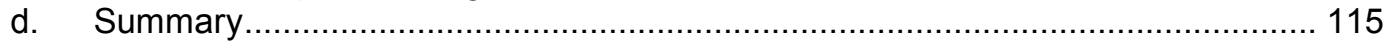

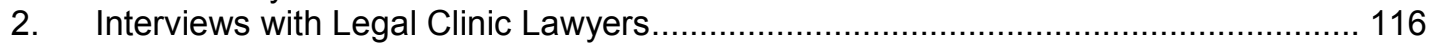

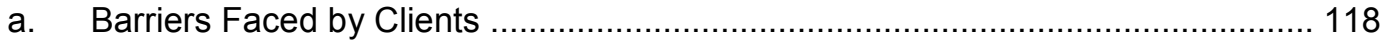

b. Differential Treatment of Racialized Clients.................................................... 120

c. Clients' Satisfaction and Perceptions of Fairness .......................................... 121

d. Before a Racialized Tribunal Member ............................................................ 127

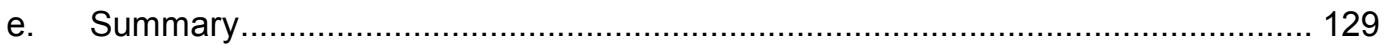

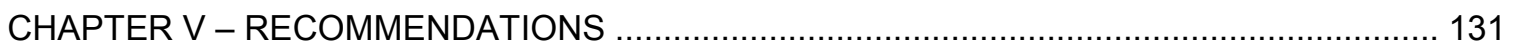

A. Implement Policies to Increase Diversity ................................................................. 131

1. Increase the Openness and Transparency of the Appointment Process .................. 134

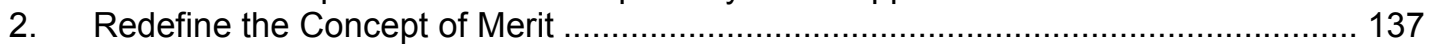

3. Track the Representativeness of Appointments ................................................ 142

4. Maintain a Database of Candidates From Racialized Groups ................................. 146

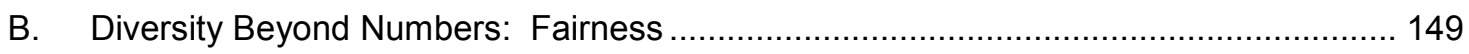

1. Foster a Vibrant Community of Judgment ....................................................... 149

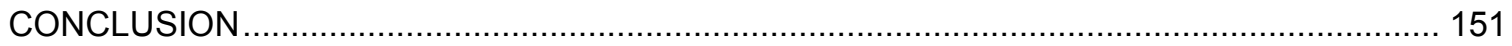

\section{List of Tables}

Table A: The Composition of Certain Federal Administrative Tribunals ................................. 101

Table B: The Composition of Governor in Council Appointees............................................. 102 


\section{INTRODUCTION AND SCOPE OF RESEARCH}

"Diversity" is widely viewed as a desirable goal. Commitments to diversity are repeated often and in a variety of contexts, ranging from the workforces and boards of private corporations to legislatures and educational institutions. As the Canadian population becomes increasingly diverse, ${ }^{1}$ the need for our institutions to become more reflective or representative of the population has indeed become an aphorism. The judiciary is one example of a powerful institution of the state that has traditionally been dominated by a narrow cross-section of Canadian society, and has not escaped calls for greater representativeness of traditionallyexcluded groups.

This thesis examines the arguments for judicial diversity and applies them to administrative tribunals with an adjudicative function. I have chosen the administrative context because, in Canada, theoretical arguments for diversity on the judiciary and in legislatures have not yet been extended to administrative tribunals. ${ }^{2}$ This despite the wide range of significant areas in which they adjudicate and the fact that individuals (and perhaps individuals from marginalized groups especially) are far more likely to have their rights and interests adjudicated by administrative tribunals than by the courts. ${ }^{3}$ The need to examine the potential impact of diversity in the administrative context is thus

\footnotetext{
${ }^{1}$ See summary of population data from the 2006 Census at 9-10, below.

${ }^{2}$ While diversity on administrative tribunals in particular has not merited a great deal of close examination, there is a significant volume of work on the concept of representative bureaucracy, particularly in the U.S. One Canadian example is Lorne Sossin's article "Discretion and the Culture of Justice" which deals with front-line decision-makers. Lorne Sossin, "Discretion and the Culture of Justice" (2006) Sing. J. Legal Stud. 356 (WL) [“Culture of Justice"].

${ }^{3}$ Administrative Justice Working Group, "Future of Administrative Justice Symposium Report" (2008) 21 Can. J. Admin. L \& Prac. 193 (quoting Chief Justice McLachlin) (WL).
} 
overdue. Moreover, I believe that diversity can be linked to two fundamental values of administrative justice: participation and justification.

In Canada, there is a multiplicity of administrative tribunals that vary considerably in their roles and functions. In this thesis, I focus exclusively on administrative tribunals that exercise an adjudicative function. Moreover, I am referring to administrative tribunals that adjudicate in areas of basic rights and needs, and are thus of critical importance to the individuals who appear before them. These include tribunals such as the Landlord Tenant Board, the Social Benefits Tribunal, the Immigration and Refugee Board and human rights tribunals. ${ }^{4}$

In my view, the arguments for diversity in public institutions such as the judiciary and legislature can largely be grouped under two distinct rationales. Briefly stated, one rationale, which I have labelled the institutional rationale, is that in a pluralist democracy such as ours, institutions of the state must be representative of the population in order for those institutions, and the decisions that they render, to be seen as legitimate. This rationale looks at diversity from a purely formalistic point of view. Calls for diversity often begin and end herediversity is thus about being fair and inclusive. By contrast, the other rationale, which I will call the individual rationale, goes further. The argument is that persons from historically excluded groups, such as racialized persons, have different, traditionally unheard perspectives on legal and political issues because of their unique background and experiences, including that of subordination. The

\footnotetext{
${ }^{4}$ For practical reasons that relate mainly to the qualitative research component of this thesis, I have focused on federal and provincial tribunals in the province of Ontario.
} 
argument is that those experiences should and must be brought to bear on decisions affecting a diverse society. The individual rationale thus envisages that diversity will have a substantive impact.

Substantive arguments for diversity are not yet broadly accepted. While the vast majority might be comfortable with the idea that public institutions should reflect the population that they serve, most are uneasy with any suggestion that this might lead to decisions that would somehow differ from those of an unrepresentative institution. This is especially true with respect to the judiciary, where firmly held beliefs about the principles of impartiality and neutrality limit our conception of the role of the judge. An example of this discomfort is the decisions of the lower courts in R. v. R.D.S., ${ }^{5}$ which found that comments made by Judge Corinne Sparks betrayed an apprehension of bias. As an AfricanCanadian judge, Judge Sparks brought and expressed a unique perspective on the facts of that case. The result was an appeal based not only on an apprehension of bias, but also the far more serious and unprecedented allegation of actual bias. It is possible to interpret this challenge to imply that while the idea of more racialized judges on the bench is uncontroversial, the potential impact of a racialized perspective on legal decisions is not.

Despite this discomfort with the individual rationale for diversity, diversity is meaningless unless it is conceived of in a manner that relates to substance. While formal considerations are both valuable and less controversial, the

\footnotetext{
${ }^{5}$ R. v. S.(R.D.), 1995 CarswellNS 608 (S.C.), Glube C.J. (orally), aff'd (1995), 145 N.S.R. (2d) 284, 102 C.C.C. (3d) 233, 1995 CarswellNS 245 (C.A.), rev'd, [1997] 3 S.C.R. 484, 161 N.S.R. (2d) 241, 118 C.C.C. (3d) 353, 1997 CarswellNS 301, 1997 CarswellNS 302. [R.D.S. cited to S.C.R., unless otherwise indicated.]
} 
institutional rationale for increased diversity is inherently self-limiting and constrains efforts to realize the true potential of diversity. Public confidence and institutional legitimacy do not result simply from constructing institutions whose compositions superficially reflect the diversity or the population. Legitimacy necessitates the inclusion of a wide range of perspectives that better reflect the diversity of the society in which we live and the potential that those perspectives may impact on legal decision-making, whether in the courts or in tribunals.

The individual rationale accounts for this potential substantive impact but it too has its limits. The focus of the "different perspectives" argument is on the impact of an individual judge or adjudicator's background and experience on his/her own decision-making. This is important in itself, but is of even greater significance when viewed in terms of its potential impact on the institution. I thus propose an integrative approach to diversity that conceives of the potential impact of diverse judges and adjudicators more broadly. The presence of diverse judges and adjudicators expands the range of knowledge, experience and perspectives available to the court or tribunal to which they belong and increases the likelihood that those perspectives will be included in the institution's decision-making.

In Baker v. Canada (Minister of Citizenship and Immigration), the Supreme Court of Canada emphasized the importance of participation and justification as core values of the administrative justice system. ${ }^{6}$ An integrative conception of diversity demonstrates how diversity can enhance participation. As a tribunal becomes more aware of and able to consider alternative perspectives

${ }^{6}$ Baker v. Canada (Minister of Citizenship and Immigration), [1999] 2 S.C.R. 817 at para. 32. 
and values that are held by the population that it serves, individuals have a better chance of having their perspectives understood and considered. Moreover, once those viewpoints are included, adjudicators must account for which values and perspectives they considered and gave precedence to in arriving at a decision in their reasons. Diversity thus also fosters the second core value articulated in Baker, supra - the principle of justification. ${ }^{7}$ Participation and justification are principles that guarantee the fairness of administrative decision-making.

Diversity is thus ultimately about fairness, which in turn furthers public confidence and legitimacy.

\section{Outline of Argument}

In Chapter I of this thesis, I examine the institutional rationale for diversity on the judiciary and apply these arguments to the administrative law context. I argue that the increasingly court-like nature and role of adjudicative administrative tribunals renders arguments for greater diversity, but more specifically, increased representation of racialized groups, equally relevant to administrative tribunals. I also demonstrate that the unique features of administrative decision-making also render formal arguments for diversity applicable to the administrative context.

Because my view is that the institutional rationale for diversity is incomplete, in Chapter II, I consider the individual rationale for diversity, that is, that diverse judges will bring different perspectives to the task of judging. I examine how experience impacts judging and how a potential substantive impact

\footnotetext{
${ }^{7}$ Baker, supra note 6 at para. 43 .
} 
challenges traditional concepts of impartiality and adjudication. I will apply these arguments to administrative adjudicators.

In Chapter III, I rely upon concepts such as "community of judgment" and

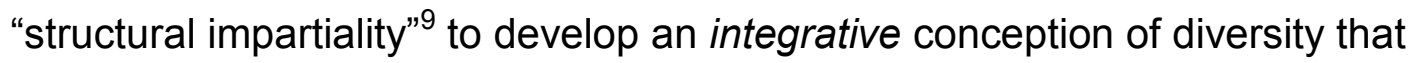
overcomes the limitations of the individual and the institutional rationales. I also apply this integrative conception of diversity to the administrative context to demonstrate how it can further participation and justification.

One of the goals of this thesis is to go beyond the theoretical arguments about diversity to determine to what extent they have any basis in practice. As a result, in Chapter IV, I propose to offer a glimpse of the value and potential impact of racially diverse adjudicators with the responses that I received from interviews conducted with both adjudicators and lawyers who appear before administrative tribunals. ${ }^{10}$ Finally, in Chapter $\mathrm{V}$, I will examine existing measures to increase the diversity of administrative tribunals and argue that if the potential benefits of diversity are to be maximized, additional measures must be adopted.

\section{CHAPTER I - LEGITIMACY AND PUBLIC CONFIDENCE: THE INSTITUTIONAL RATIONALE FOR THE DIVERSITY OF LEGAL DECISION-MAKERS}

\section{A. Constructing a Meaningful Conception of Diversity}

In order to discuss the need for greater diversity in institutions such as the judiciary or administrative tribunals, it is first necessary to arrive at an

\footnotetext{
8 Jennifer Nedelsky, "Judgment, Diversity and Relational Autonomy" in Jennifer Nedelsky \& Ronald Beiner, eds., Judgment, Imagination and Politics, (Lanham: Rowman \& Littlefield Publishers, 2001) 103 at 113 [“Relational Autonomy"].

${ }^{9}$ Sherrilyn A. Ifill, "Judging the Judges: Racial Diversity, Impartiality and Representation on State Trial Courts" (1997) 30 B.C.L. Rev. 95 at 99 (WL) [hereinafter "Judging the Judges"].

${ }^{10}$ Due to the limited scope of my qualitative research, I do not purport to do any more than to offer a glimpse of the potential impact of diverse adjudicators on administrative decision-making.
} 
understanding of what we mean by "diversity." Thus far I have used both the terms "diversity" and "representativeness" to refer to the goal of increasing the number of individuals from certain groups on the judiciary and in administrative tribunals. The term "diversity" is employed with increasing frequency in a variety of contexts, and it is assumed, generally speaking, to mean the inclusion of a wide range of the various social groups in Canadian society. Diversity might best be understood in negative terms, or as the opposite of homogeneity, where the presence of a single group dominates. While a lack of diversity is easy to identify, what we hope to attain by "diversity" is more difficult to envisage. Diversity, though widely-used, is rarely defined and its precise meaning remains vague.

Generally speaking, diversity can be defined as "variety" or the "quality of being different." ${ }^{11}$ The U.K. Department for Constitutional Affairs' consultation paper on diversity in the judiciary defines diversity as: "[t]he presence among a group of individuals of a wide variety of backgrounds, cultures, opinions, styles, perspectives, values and beliefs." ${ }^{12}$ This definition, however, provides little in the way of specifics. Unless it is further defined, diversity on the judiciary could simply encompass factors such as judges' career paths, educational backgrounds or political affiliations. ${ }^{13}$ Thus, diversity can be an amorphous term

\footnotetext{
${ }^{11}$ Sheila Foster, "Difference and Equality: A Critical Assessment of the Concept of 'Diversity"' (1993) Wisc. L. Rev. 105 at 135.

${ }^{12}$ Erica Rackley, "Judicial Diversity, the woman judge and fairy tale endings" (2006) 27 Legal Studies 74 at 86, quoting Department of Constitutional Affairs, Increasing Diversity in the Judiciary (CP 25/04, October 2004) at 57.

${ }^{13}$ As the Right Honourable Dame Brenda Hale, Lord Justice of Appeal of the House of Lords remarks, her colleagues are "a remarkably diverse bunch" but not at all representative. Dame Brenda Hale, "Equality and the Judiciary: Why Should We Want More Women Judges?" (2001) Public Law 489 at 502 ["More Women Judges"].
} 
subject to manipulation depending upon one's purpose. This has led some scholars to criticize diversity as an empty concept. ${ }^{14}$ As one author notes:

Diversity-light does little more than scratch the surface of the bench, allowing the more invidious effects of a homogenous judicial culture and instinctive understandings of the judge and judging to continue relatively unscathed. ${ }^{15}$

The failure to define diversity leads only to more questions. Which of the many diverse groups in society must be included? What characteristics or aspects of identity are relevant to the goal of diversity? For example, does diversity mean that the inclusion of individuals from racialized groups is sufficient, or does it mean that individuals from each of the many racialized groups (Black, Asian, South Asian, other) must be present? How will we determine when an organization is sufficiently diverse?

\section{Diversity Is About Equality}

In my view, when discussing the composition of public institutions, the concept of diversity lacks substance unless it encompasses two fundamental principles: equality and representativeness. Diversity cannot simply mean variety, such that characteristics such as one's hair colour or alma mater are sufficient considerations. Moreover, diversity should neither include all differences nor treat all differences as equal. This leads to the question of which differences matter. ${ }^{16}$ In my view, in order to have meaning, diversity must be animated by the egalitarian objective of including groups who, on the basis of their differences, have traditionally been excluded from institutions of power and authority. Therefore, inherent in any call for greater diversity on the judiciary or

\footnotetext{
${ }^{14}$ Foster, supra note 11 at 111 and 133.

${ }^{15}$ Rackley, supra note 12 at 93.

${ }^{16}$ Foster, supra note 11 at 131.
} 
on administrative tribunals is an understanding that such diversity is intended to rectify the historical under-representation of particular, marginalized groups. ${ }^{17}$

Discussions about diversity generally recognize the need to include women, racialized persons, aboriginal peoples, persons with disabilities, and gays and lesbians, but could potentially extend to others, for example, the economically disadvantaged. Rather than to identify the relevant groups, it is perhaps more beneficial to examine particular characteristics that necessitate the inclusion of certain groups in the goal of diversity. ${ }^{18}$ In her work on representation, Melissa Williams uses the term "marginalized ascriptive groups" to describe groups that have been chronically under-represented. ${ }^{19}$ Such groups exhibit four characteristics:

(1) patterns of social and political inequality are structured along the lines of group membership;

(2) membership is not generally experienced as voluntary;

(3) membership is not usually experienced as mutable; and

(4) negative meanings are assigned to group identity by the broader society or dominant culture. ${ }^{20}$

Williams thus cites women and African Americans are paradigmatic examples of historically marginalized ascriptive groups in American society. The focus of my thesis is race because of my conviction that any concept of diversity,

\footnotetext{
17 Ibid. at 155: "Including those individuals with differences who historically have been systematically excluded should be, at a minimum, an explicit goal of a concept of diversity."

${ }^{18}$ Sonia Lawrence observes that those categories can be fluid and overlapping, thus adding additional complexity. Sonia Lawrence, "Reflections: On Judicial Diversity and Judicial Independence" (2008) [unpublished] at 12.

${ }^{19}$ Melissa S. Williams, Voice, Trust, and Memory: Marginalized Groups and the Failings of Liberal Representation, (Princeton: Princeton University Press) at 16.

${ }^{20} \mathrm{lbid}$. Lawrence notes that "[w]e should not underestimate the significance of the choice of 'relevant' difference, since these choices participate in the creation and recognition of the categories we claim to merely recognize." Lawrence, supra note 18 at 10.
} 
especially as it relates to the composition of the judiciary and administrative tribunals, must be informed by an objective of correcting historical underrepresentation of groups that have been marginalized on the basis of race.

\section{a. Race is a "Salient Difference"}

As noted above, any argument for diversity is almost immediately confronted by the question - diversity based on what characteristics? While I do not attempt to arrive at a conclusive list of the groups that must be included when defining diversity, my view is that efforts to make public institutions more diverse or representative must recognize the need to include persons from racialized groups. ${ }^{21}$ Racial and ethnic diversity is one of the notable features of Canadian society. Census data from 2006 (the "2006 Census") reported the presence of 200 ethnic groups in Canada making it one of the most ethnically diverse countries in the world. ${ }^{22}$ The population has and will continue to become increasingly diverse in terms of race. According to the 2006 Census, the "visible minority" population of Canada is $5,068,000$, constituting 16.2 percent of the country's population. ${ }^{23}$ This was an increase from 13.4 percent of the population in 2001. ${ }^{24}$ Between 2001 and 2006, Canada's visible minority population increased by $27.2 \% .{ }^{25}$ Ontario is home to one-half of Canada's visible minority population. ${ }^{26}$ Members of visible minorities make up 23 percent of the population

\footnotetext{
${ }^{21}$ See also, Williams, supra note 19.

22 Statistics Canada, 2008, "Canada's Ethnocultural Mosaic, 2006 Census: Highlights", online: $<$ http://www12.statcan.ca/english/census06/analysis/ethnicorigin/highlights.cfm>.

${ }^{23}$ Ibid.

24 Ibid.

${ }^{25} \mathrm{Ibid}$.

${ }^{26}$ Statistics Canada, 2008, "Canada's Ethnocultural Mosaic, 2006 Census: Provinces and Territories", online: Statistics Canada <http://www12.statcan.ca/english/census06/analysis/ethnicorigin/ontario.cfm>.
} 
of Ontario ${ }^{27}$ and over 42.9 percent of the population of the metropolitan area of Toronto. ${ }^{28}$ As Canada's population growth depends upon immigration from nonwhite countries, ${ }^{29}$ growing racial diversity will continue to be a characteristic of Canadian society. The increasing proportion of racialized groups among the population means that government institutions, unless they rapidly include more racialized persons, will only become less and less representative with time.

More important than the statistics, however, is the fact that race has been used throughout Canadian history to differentiate certain groups from others and has served to marginalize and systematically exclude racialized groups from holding power. ${ }^{30}$ The impact of this long history of subordination continues to be felt today through the assignment of particular characteristics to racialized groups, resulting in persistent and pervasive assumptions and stereotypes. ${ }^{31}$ Canadians, often in comparison to the United States, like to believe that racism does not exist in Canadian society ${ }^{32}$ or has not left the same taint on our country's history that it has south of the border. Such a belief is simply not consistent with the record of subordination of various racialized groups through

\footnotetext{
${ }^{27}$ Ibid.

${ }^{28}$ Statistics Canada, 2008, "Canada's Ethnocultural Mosaic, 2006 Census: Canada's major census metropolitan areas", online: Statistics Canada <http://www12.statcan.ca/english/census06/analysis/ethnicorigin/toronto.cfm>.

${ }^{29}$ Between 2001 and 2006, Canada's foreign-born population increased by $13.6 \%$. This was four times higher than the Canadian-born population, which grew by $3.3 \%$ during the same period.

Statistics Canada, 2008, "Immigration in Canada: A Portrait of the Foreign-born Population, 2006 Census: Immigration: Driver of population growth", online: Statistics Canada $<$ http://www12.statcan.ca/census-recensement/2006/as-sa/97-557/p2-eng.cfm>.

${ }^{30}$ Foster, supra note 11 at 135.

${ }^{31}$ Ibid. at 136.

${ }^{32}$ Carol A. Aylward, Canadian Critical Race Theory: Racism and the Law (Halifax: Fernwood Publishing, 1999) at 77.
} 
policies leading to segregation, denial of citizenship and voting rights, destructive assimilation, and internment. ${ }^{33}$

Racism continues to have an impact on contemporary society. In the case of $R$. v. Parks, the Ontario Court of Appeal recognized that:

Racism, and in particular anti-black racism, is a part of our community's psyche. A significant segment of our community holds overtly racist views. A much larger segment subconsciously operates on the basis of negative racial stereotypes. Furthermore, our institutions, including the criminal justice system, reflect and perpetuate those negative stereotypes. These elements combine to infect our society as a whole with the evil of racism. Blacks are among the primary victims of that evil. ${ }^{34}$

Similarly, in R. v. Williams, the Supreme Court of Canada unanimously recognized that judicial notice may be taken of widespread racial prejudice in the community. ${ }^{35}$ Moreover, the belief that racism does not exist is contradicted by the experience of racialized groups in Canada, as evidenced by numerous social science studies in a variety of contexts. ${ }^{36}$

Racism has traditionally been associated with ascribing inferiority to persons with darker skin, but because society now purports not to tolerate racism, current forms of racism are subtler and therefore more difficult to detect. "Democratic racism" describes the coexistence of a commitment to democratic principles such as justice, fairness and equality with attitudes and behaviours that include discrimination, differential treatment, and negative feelings about racialized groups. ${ }^{37}$ This "new racism" consists of "a set of complex processes that facilitate a more subtle way of justifying the subordination of those with

\footnotetext{
${ }^{33} \mathrm{Ibid}$. at $77-80$.

${ }^{34}$ R. v. Parks (1993), 15 O.R. (3d) 324; 84 C.C.C. (3d) 353; 1993 Carswell 119 at $\mathbb{} 54$ (C.A.) (eC).

${ }^{35}$ R. v. Williams, [1998] 1 S.C.R. 1128 at para. 54.

${ }^{36}$ Frances Henry,et al. The Colour of Democracy: Racism in Canadian Society, $2^{\text {nd }}$ ed. (Toronto: Harcourt Canada Ltd., 2000).

${ }^{37}$ Ibid. at 23.
} 
darker skin." ${ }^{38}$ A recent study of 41,666 immigrants from different ethnic backgrounds found that skin colour, and not religion or income, was the biggest barrier to feeling that they belonged in Canada. ${ }^{39}$ Almost one-quarter of visible minorities report feeling uncomfortable or out of place on the basis of ethnocultural characteristics some, most or all of the time.$^{40}$ Despite the racial diversity of Toronto, members of racialized groups are far more likely to be poor than nonracialized persons, ${ }^{41}$ are more likely to be treated differently by the criminal justice system, ${ }^{42}$ have more difficulty finding employment, ${ }^{43}$ and are less likely to be in positions of authority. ${ }^{44}$ In short, skin colour continues to have a widerange of potential consequences on the social well-being of racialized persons. Marginalization based on race thus remains an issue in Canadian society that has not been sufficiently addressed, let alone remedied. Because race is a social construction that has been used to systematically exclude certain

\footnotetext{
${ }^{38}$ Audrey Kobayashi and Genevieve Fuji-Johnston, "Introduction" in A. Kobayashi and Randy Enomoto, eds. Race, Racialization, and Antiracism in Canada and Beyond (Toronto: University of Toronto Press, 2007) at 9.

${ }^{39}$ Lesley Ciarula Taylor, "Darker the Skin, Less you Fit" Toronto Star, (14 May 14 2009), online: Toronto Star <http://www.thestar.com/news/gta/article/634117. See also: Jeffrey G. Reitz, Rupa Banarjee, et al. "Race, Religion, and the Social Integration of New Immigrant Minorities in Canada" Int'I Migration Rev. [forthcoming in 2009].

${ }^{40}$ Statistics Canada, "Ethnic Diversity Survey: portrait of a multicultural society" (Ottawa: Ministry of Industry, 2008) at 16, online: Statistics Canada <http://www.statcan.gc.ca/pub/89593-x/89-593-x2003001-eng.pdf.

${ }^{41}$ In Toronto, racialized families are two to four time more likely to fall below the low income cutoff than non-racialized families. "Understanding the racialization of poverty in Ontario in Income Levels and Social Assistance in 2007" online: http://cop.openconcept.ca/./sites/colourofpoverty.ca/files/FactSheet 6 Income.pdf.

${ }^{42} \mathrm{~F}$. Henry, supra note 36 at $146-48$.

${ }^{43}$ Ibid. at 103.

${ }^{44}$ Wendy Cukier and Margaret Yap, "DiversityCounts A Snapshot of Diversity in the Greater Toronto Area: The first annual report research report measuring diversity among leaders" (May 2009), online: Maytree Foundation <http://maytree.com/PDF Files/DiversecityCounts/DiverseCityCountsReportFinal.pdf. $>$ In a study of visible minorities in leadership positions, the authors found that $13 \%$ of the 3257 leaders we studied are visible minorities. Leadership positions were defined as elected offices and in the most senior roles in the corporate and public sectors, agencies/boards/commissions, charities/foundations, and schools/colleges/universities.
} 
individuals to their disadvantage, race must be considered a "salient difference" or one of the characteristics that matters when discussing the objective of greater diversity. ${ }^{46}$

I do not argue that racialized groups can "speak for" other marginalized groups in Canadian society. The experience of racialized groups with subordination and marginalization can, however, provide perspectives on other forms of subordination, such as that based on socio-economic class, that are closely aligned with race. ${ }^{47}$ Therefore, while my focus is race, it is possible that similar arguments could be made for increased representation of other traditionally excluded groups.

Finally, I note that by using the term "race," I do not accept or attribute any biological significance to the concept of race or of any race-based categorizations. Race is a social construction. ${ }^{48}$ Through the process of racialization, bodies and physical characteristics are ascribed symbolic meaning, which has then been employed to assign social significance. ${ }^{49}$ As such, I have chosen to use the term "racialized groups" or racialized persons as opposed to "minorities" or any variation on that term (ethnic, racial or visible minorities) to refer to non-Aboriginal individuals of non-Caucasian, non-European origin. At the same time, "racialized groups" do not constitute a homogenous, monolithic

\footnotetext{
${ }^{45}$ Foster, supra note 11 at $134-35$.

${ }^{46}$ See also, Duncan Kennedy, "A Cultural Pluralist Case for Diversity in Legal Academia" (1990) Duke L.J. 705 at 713 (WL) ("Race is, at present, a rough but adequate proxy for connection to a subordinated community.... [but] is only one of the multiple forms of group subordination.")

47 Ifill, "Judging the Judges" supra note 9 at 121-22.

${ }^{48}$ See Henry et al., supra note 36 at 5: "The concept of race has no basis in biological reality and, as such, has no meaning independent of its social definitions. But, as a social construction, race significantly affects the lives of people of colour." See also Kobayashi, supra note 38 at 5 .

${ }^{49}$ Henry, supra note 36 at 5 ; Kobayashi, supra note 38 at 5.
} 
entity and it is important to recognize the vast diversity among and within different racialized groups. ${ }^{50}$ Moreover, additional characteristics, such as gender, disability, sexual orientation and income level have further effects upon the experience of racialized persons. ${ }^{51}$ All of these factors render it impossible to speak of racialized persons as a uniform group, or of a single racialized experience or perspective.

\section{Diversity as Representativeness}

The second essential principle of diversity, representativeness, is not necessarily incorporated in definitions of diversity, such as the U.K. definition quoted earlier. Unlike diversity, which could simply refer to variety or difference, representativeness is a comparative concept. ${ }^{52} \mathrm{~A}$ representative institution is one that more closely reflects the society that it serves. In other words, diversity has to do with representation of the relevant social groups in society in proportion to the population. ${ }^{53}$

Diversity must be rooted in some notion of representativeness or it otherwise risks lacking any correlation to the society in which the institution is situated. For example, the judiciary in Toronto could be considered diverse if it included more Francophone, women, and disabled judges, but an absence of racialized judges would still result in an unacceptable gap, given that racialized persons constitute almost 40 percent of the city's population. In addition, the

\footnotetext{
${ }^{50}$ A further discussion of essentialism is found at 57 , below.

${ }^{51}$ The different impact of discrimination based on multiple characteristics, such as gender and race, has been referred to as intersectionality. See Kimberle Crenshaw, "Race, Reform and Retrenchment: Transformation and Legitimation in Antidiscrimination Law" (1988) 101 Harv. L. Rev. 1331.

${ }^{52}$ Lawrence, supra note 18 at 13.

${ }^{53}$ Ibid.
} 
pursuit of diversity without any reference to representativeness could become an exercise in tokenism, ${ }^{54}$ where "diversity" is seemingly attained by the inclusion of one or two individuals from each of the social groups that are identified.

In Canada, the principle of representativeness has long been accepted in certain contexts. For example, regional representation motivates the allocation of a certain number of seats for each province in the House of Commons and the Senate ${ }^{55}$ The desire to maintain regional representation is also seen in the composition of the Supreme Court of Canada, which, as dictated by custom, consists of three judges from Ontario, three judges from Quebec, two judges from the Western provinces, and one judge from the Atlantic provinces. ${ }^{56}$ Also traditionally important has been the representation of Canada's linguistic duality, as seen in the legislative requirement of three judges of the Supreme Court from Quebec $^{57}$ as well as the alternation between French and English-speaking governors-general and speakers of the House. It might also be possible to argue that gender representation has also become an important feature of the Supreme Court. More recently, both linguistic and regional representation, as well as gender and racial diversity, are taken into consideration by Prime Ministers when they select their Cabinet ministers. ${ }^{58}$

Thus, the value of representativeness has gone unquestioned with respect to certain aspects of the diversity of the Canadian population. This reflects a tacit

\footnotetext{
${ }^{54}$ Ibid. at 13.

${ }^{55}$ Constitution Act, 1867 (U.K.), 30 \& 31 Vict., c. 3, reprinted in R.S.C. 1985, App. II, No. 5, ss. 29 and 51.

${ }^{56}$ This regional representation is not statutorily required but has become a constitutional convention. Lawrence, supra note 18 at 10.

${ }^{57}$ Supreme Court Act, R.S.C. 1985, c. S-26, s. 6.

58 Julie Jai \& Joseph Cheng, "The Invisibility of Race in Section 15: Why Section 15 of the Charter Has Not Done More to Promote Racial Equality" (2006) 5 J.L. \& Equality 125 I 64 (QL).
} 
recognition of the need to ensure a voice for less populous provinces and the Francophone minority who might have interests that differ from central Canada and the Anglophone majority. It has not followed, however, that the principle of representation has been extended to other groups, such as racialized groups or Aboriginal peoples, even though those groups are more likely to be underrepresented and disregarded in political decision-making. ${ }^{59}$ For example, despite the volume of cases relating to treaty rights and aboriginal land claims, recommendations to appoint an Aboriginal judge to the Supreme Court have thus far gone unfulfilled.

The difficulty with the use of the term representativeness, however, is that because it necessarily requires a correlation to the population in question, it seems to imply a degree of precision that would be difficult to ascertain or to achieve. Moreover, the discussion could become unduly mired in numbers and percentages. The concept of representativeness also raises further questions as to which population a given institution must reflect: the immediate community, city, province or country. These are difficult questions for which there are no simple answers. Therefore, I will continue to use the term "diversity", noting that my definition of diversity does not simply mean variety or token inclusion of the different social groups that form Canadian society but is instead rooted in the principles of equality and representativeness. This vision of diversity more squarely highlights the historical under-representation of certain groups, such as

\footnotetext{
${ }^{59}$ Will Kymlicka, "Three Forms of Group-Differentiated Citizenship in Canada" in S. Benhabib, ed., Democracy and Difference: Contesting the Boundaries of the Political (Princeton: Princeton University Press, 1996) at 157.
} 
racialized persons and the impact of such under-representation. As Sonia

Lawrence notes:

Calling for representation more squarely confronts the ways in which a homogenous - or otherwise non-representative - bench threatens impartiality, by calling attention to the disparity between the judges and the judged. ${ }^{60}$

\section{a. The Necessity of Group Representation}

A conception of diversity that has its roots in representativeness brings

into the analysis the concept of representation, which has been much examined in the legislative context but less so in relation to the judiciary. While an in-depth analysis of the concept of political representation is beyond the scope of this paper, I will touch briefly on the argument that judges can and do act as representatives and that the failure to view them as such is tied to our limited conception of the judicial function. ${ }^{61}$

Broadly speaking, representation is the "bringing into presence of something previously absent, or the embodiment of an abstraction in an object." 62 Representatives do not always act in the same way, as this depends upon the nature of the representation. A representative can: (1) act for a community (descriptive representation); (2) take care of a community (substantive

\footnotetext{
${ }^{60}$ Lawrence, supra note 18 at 13.

61 Ifill, "Judging the Judges" supra note 9 at 134-40; Lawrence, ibid at 13-14.

${ }^{62}$ Hanna Fenichel Pitkin, The Concept of Representation (Berkeley: University of California Press, 1967). As Anne Phillips notes, Pitkin felt that what representatives did was more important than who they were: "Think of the legislature as a pictorial representation or a representative sample of the nation, and you will almost inevitably concentrate on its composition rather than its activities." Anne Phillips, "Dealing with Difference: A Politics of Ideas, or a Politics of Presence?" in Benhabib, supra note 59 at 141 (quoting Pitkin). Phillips notes that while questions of power and inequality did not figure largely in Pitkin's account, those questions are now central to democratic debate.
} 
representation); (3) substitute another (symbolic representation) or (4) be sent by another (formal representation). ${ }^{63}$

At first glance, it would appear incongruent to speak of judges as representatives. The independence and impartiality required of courts and tribunals would seem to prohibit judges and adjudicators from acting as representatives in any way. However, judges do not necessarily act as representatives in the sense that they advocate for certain positions. Contrary to popular belief, even in the legislature, representatives are not always required to act according to the will of those that they represent. ${ }^{64}$ The representative role of judges requires only that judges give constituent communities the opportunity for the expression of their values and views in public policy. ${ }^{65}$ Judges thus exercise their representative function in the judicial decision-making process, not merely through outcomes. ${ }^{66}$ Martha Minow argues that "[j]udges can and should act as representatives, standing in for others and symbolizing society itself." ${ }^{67}$ Judges as representatives should thus seek to include and engage the multiple and competing perspectives of the communities they serve in the process of judicial decision-making. ${ }^{68}$

Some political scientists have advocated group representation to overcome chronic under-representation of marginalized groups in public institutions. Thus, Anne Phillips argues that, due to a more complex

\footnotetext{
${ }^{63}$ Ifill, "Judging the Judges" supra note 9 at 134-35.

$64 \mathrm{Ibid}$. at $466-67$.

${ }^{65} \mathrm{Ibid}$. at $134-35$.

${ }^{66}$ Sherrilyn A. Ifill, "Racial Diversity on the Bench: Beyond Role Models and Public Confidence" (2000) 57 Wash. \& Lee. L. Rev. 405 at 416 ["Racial Diversity"].

${ }^{67}$ Martha Minow, "Justice Engendered: The Supreme Court, 1986 Term" (1987) 101 Harv. L. Rev. 10 at 81 ["Justice Engendered"].

${ }^{68}$ Ifill, "Racial Diversity" at 416.
} 
understanding of the relationship between ideas and experience, political exclusion is increasingly viewed in terms that can only be remedied by political presence. ${ }^{69}$ In addition, Williams' "voice" model of representation questions the ability of others to represent marginalized groups and also requires the presence of marginalized groups in the legislative context. According to Williams, the heavily deliberative quality of legislative institutions is an additional feature that necessitates the presence of individuals who have direct access to historically excluded perspectives. ${ }^{70}$ As will be seen in subsequent parts of this thesis, these arguments are also relevant to the administrative context.

\section{B. Diversity As Furthering Democratic Legitimacy}

A concept of diversity that is founded on the principles of equality and representativeness in institutions such as the judiciary and administrative tribunals leads to what I have labelled the "institutional" rationale for diversity. Underlying the institutional rationale are concerns about the composition of institutions of the state in a diverse and democratic society. As noted above, political scientists have questioned the ability of traditional liberalism to deal with difference. ${ }^{71}$ The difference-blind approach that has resulted from abstract principles of equality and universality has not translated into equal participation in government institutions by traditionally marginalized groups. ${ }^{72}$ In a society that values the equality of all individuals, the lack of access to certain forms of power to substantial portions of the population not only brings into question the authority

\footnotetext{
${ }^{69}$ Phillips, supra note 62 at 141.

${ }^{70}$ Williams, supra note 19 at 143-45.

${ }^{71}$ See, e.g. Williams, supra note 19, Phillips, supra note 62, Carol C. Gould, "Diversity and Democracy: Representing Differences" in Benhabib, supra note 59.

${ }^{72}$ Williams, supra note 19 at $75-82$.
} 
of those in power, but also raises doubts about the extent to which individuals are truly equal. ${ }^{73}$

\section{A Lack of Diversity Compromises Legitimacy}

The democratic argument for a more representative judiciary can be seen as an offshoot of the principle of representative government. The judiciary is a powerful institution of the state that renders decisions that define basic rights and individuals' relationships to the state. Because courts not only enforce, but also make the law, ${ }^{74}$ participation by the broader population, and not simply a "privileged fraternity," is necessary. ${ }^{75}$ Otherwise, the exercise of such power by a narrow cross-section of society results in a "democratic deficit," ${ }^{76}$ similar to that which results when certain groups are excluded from the legislative branch of government.

Scholars in the United States point to the "crisis of legitimacy"77 that results from the disparity between the judges and the judged. Indeed, the U.S. provides a stark example of the democratic deficit created when the judiciary is composed of a narrow cross-section of society, as white men disproportionately make judgments affecting African-Americans, women, and other minorities. The courts are thus viewed as continuing the subordination of marginalized groups.

\footnotetext{
73 "In a democratic society, in which we are all equal citizens, it is wrong in principle for that authority to be wielded by such a very unrepresentative section of the population." Dame Hale, "More Women Judges" supra note 13 at 502.

${ }^{74}$ The Right Honourable Beverly McLachlin, P.C., "The Role of Judges in Modern Society" (The Fourth Worldwide Common Law Judiciary Conference, Vancouver, 5 May 2001), online: Supreme Court of Canada <http://www.scc-csc.gc.ca/AboutCourt/judges/speeches/role-ofjudges e.asp> ["Modern Society"]

${ }^{75}$ Richard Devlin et al. "Reducing the Democratic Deficit: Representation, Diversity and the Canadian Judiciary, or Toward a 'Triple P' Judiciary” (2000) 38 Alta L.R. 734 at 791.

${ }^{76}$ Ibid.

77 James Andrew Wynn, Jr. \& Eli Paul Mazur, “Judicial Diversity: Where Independence and Accountability Meet” (2003) 67 Alb. L. Rev. 775 at 781.
} 
Although the contrast may be less striking in Canada, with respect to Aboriginal peoples and African Canadians, there is nonetheless a "massive overrepresentation as accused in the legal system, but significant underrepresentation as judges in that same system."78

A second aspect of the democratic argument for judicial diversity is based in conventional, liberal principles of the right to equal opportunity, that is, that all individuals, regardless of racial or ethnic background, have an equal right to participate in government institutions. ${ }^{79}$

For if individuals have an equal right to determine their own actions and further, if engaging in common activity is one of the necessary conditions for their selfdevelopment, then it follows that there is an equal right to participate in determining the course of such common activity. This includes participation in decision-making, in the institutions of work, that is in the firm, in social and cultural institutions, as well as in contexts of politics and government. ${ }^{80}$

As equal citizens, subject to the laws as interpreted, applied and made by the courts, all groups should thus have an equal right to share in the exercise of that particular form of power. ${ }^{81}$

Finally, to the extent that the judiciary remains composed of persons from a particular background (white, male, middle-to-upper class), as an institution it perpetuates gender and race-based stereotypes, myths and biases about who can and should wield the type of power that the judiciary possesses. As Chief Justice McLachlin has noted, "we all possess a certain image of a judge. He is

\footnotetext{
${ }_{78}^{78}$ Devlin, supra note 75 at 790.

79 Ibid. at 789. See also Judge Harry T. Edwards, "Race and the Judiciary" (2002) 20 Yale L. \& Pol'y Rev. 325 at 328 ("It is therefore imperative that blacks in American society have a full and fair opportunity to participate in our systems of governance, including our courts, lest the promise of equality ring hollow.")

80 Gould, supra note 71 at 181.

${ }^{81}$ Anita Hill, "The Embodiment of Equal Justice Under the Law" (2007) 31 Nova L. Rev. 237 at 239.
} 
old, male, and wears pinstriped trousers." ${ }^{82}$ Increasing the number of racialized persons on the judiciary is important to eliminating those stereotypes. ${ }^{83}$ The effect of increased diversity on the bench in this context is two-fold. First, for members of historically disadvantaged groups, participation and reflection in institutions of the state is a sign of inclusion and can enhance self-perception as well as lead to the identification of achievable goals. ${ }^{84}$ Second, for the general public, a more representative judiciary can counter negative stereotypes and "foster attitudinal change" 85 about certain groups. A more diverse judiciary would thus embody the principles of equality and representativeness that are valued in a pluralist democracy.

\section{Diversity Fosters Public Confidence in the Justice System}

Closely related to the argument that democratic legitimacy requires a diverse judiciary is the argument that public confidence in the institution of the judiciary requires greater representation of racialized groups. As Devlin notes, "[t]he legitimacy of the judicial system is contingent upon public confidence." ${ }^{" 86}$ Not only is it fundamentally undemocratic for a single group to dominate the judiciary, the decisions of such an exclusive body might not be viewed as legitimate by the groups that are not included in that institution. As Judge Richard Posner ${ }^{87}$ argues, a diverse "judiciary is more representative, and its

\footnotetext{
${ }^{82}$ Chief Justice McLachlin, "Modern Society" supra note 74. Dame Hale also observes that "this ideal picture of the judge - anonymous, dehumanised, impartial, authoritative - is intrinsically male." Dame Hale, "More Women Judges" supra note 13 at 497.

${ }^{83}$ Susan Moloney Smith, "Diversifying the Judiciary: The Influence of Gender and Race on Judging" (1994) 28 U. Rich. L. Rev. 179 at 197 (WL).

${ }^{84}$ Devlin, supra note 75 at 797.

${ }^{85} \mathrm{Ibid}$. at 797.

${ }^{86} \mathrm{Ibid}$. at 796.

${ }^{87}$ U.S. Court of Appeals for the Seventh Circuit.
} 
decisions will therefore command greater acceptance in a diverse society than would the decisions of a mandarin court." ${ }^{88}$ There is some Canadian research that suggests that marginalized communities have significant concerns about the justice system. ${ }^{89}$ In the U.S., there is abundant research that indicates that African Americans, including African American lawyers and judges, have serious doubts about the fairness of the criminal justice system. ${ }^{90}$

The belief is thus that increasing the number of racialized persons on the judiciary would encourage public confidence in the courts. Dame Brenda Hale cites a recent U.K. study of ethnic minority magistrates, which found that the most common recommendation made by the magistrates to increase ethnic minority confidence in the courts was to recruit more magistrates and court staff from the local minority populations. ${ }^{91}$

The institutional rationale for judicial diversity is thus that people will have more confidence in a judiciary that looks more like them. It attempts to remedy concerns about the legitimacy of unrepresentative institutions in a diverse and democratic society and is thus also applicable to the administrative law context.

\footnotetext{
${ }^{88}$ Richard Posner, Law, Pragmatism, and Democracy (Boston: Harvard University Press, 1993) at 120.

${ }^{89}$ Ontario, Final Report of the Commission on Systemic Racism in the Ontario Criminal Justice System (Toronto: Queens Printer, 1995) (Co-chairs: M. Gittens \& D. Cole), cited in Devlin, supra note 75 at 796 . In a recent online survey, two-thirds of respondents $(65 \%)$ responded that they think the justice system in Canada fails to treat every person fairly. Angus Reid Strategies, "Canadians Think the National Justice System Is Not Fair to Everyone" (July 17, 2008) online: Angus Reid <httpp://angusreidstrategies.com/uploads/pages/pdfs/2008.07.17_JusticelV.pdf>. 90 Ifill, "Racial Diversity" supra note 66 at 435.

91 J. Vennard, G. Davis, J. Baldwin and J. Pearce, Ethnic Minority Magistrates' Experience of the Role and of the Court Environment, Department for Constitutional Affairs Research Series 3/04, 2004, cited in The Right Honourable Baroness Brenda Hale of Richmond, "The Appointment and Removal of Judges: Independence and Diversity" (Paper presented to the International Association of Women Judges, Sydney, May 2006) at 2 ["Appointment and Renewal"].
} 


\section{The Institutional Rationale for Diversity Applies to Administrative $\underline{\text { Tribunals }}$}

\section{Administrative Tribunals - Akin to Courts or Distinct?}

It is difficult to characterize administrative tribunals generally because of the number and variety of governmental bodies that would fall under the definition of "tribunals" and because of the broad range of areas in which they operate. Administrative tribunals have different roles and functions, depending upon their legislative mandates and areas of expertise. The term "tribunal" applies to bodies as varied as the Immigration and Refugee Board or Human Rights Tribunal, as well as the Commissioner of Patents or Ontario Municipal Board. Some tribunals are responsible for the development and implementation of policy, while others have a mainly adjudicative role. ${ }^{92}$

While calls for diversity are also undoubtedly relevant to administrative boards and regulatory agencies, the arguments made in this paper are limited to administrative tribunals that perform an adjudicative function and are therefore most akin to the courts. For the purposes of this analysis, I am focusing on administrative tribunals that adjudicate in areas of social policy that affect fundamental rights, basic needs and entitlements and whose decisions are of critical importance to the individuals who appear before them. These include tribunals such as the Immigration and Refugee Board, the Social Benefits Tribunal and the Landlord and Tenant Board and human rights tribunals. ${ }^{93}$

\footnotetext{
${ }^{92}$ Lorne Sossin, "Speaking Truth to Power? The Search for Bureaucratic Independence in Canada" (2005) 55 U. Toronto L.J. 1 at 53 [“Speaking Truth"].

${ }_{93}$ This is not intended to be an exhaustive list of the adjudicative tribunals to which arguments for increased diversity could apply.
} 
In terms of the constitutional separation of powers, administrative tribunals "may be seen as spanning the constitutional divide between the executive and judicial branches of government." ${ }^{\text {94 }}$ Administrative tribunals occupy a unique and ambiguous position because while they technically fall under the executive branch of government, they must be seen to act independently from the executive.$^{95}$ In the debate about the degree of independence required of administrative tribunals, the similarities and differences between the functions of administrative tribunals and the courts are often highlighted. ${ }^{96}$ Indeed, the test for tribunal independence is derived from the test applied for judicial independence. ${ }^{97}$ The independence required of a tribunal varies according to its legislative mandate and function. Those that are closer to the executive end of the spectrum are subject to less stringent requirements of independence while those at the judicial end of the spectrum are subject to almost court-like standards of independence. ${ }^{98}$

On the one hand, administrative tribunals act increasingly like courts in that they adjudicate disputes on innumerable aspects of key importance to the daily lives of many individuals who appear before them ${ }^{99}$ and to the development

\footnotetext{
${ }^{94}$ Ocean Port Hotel Ltd. v. British Columbia (General Manager, Liquor Control and Licensing Branch), [2002] 2 S.C.R. 781 at para. 24.

${ }^{95}$ Lorne Sossin, "The Uneasy Relationship Between Independence and Appointments in Canadian Administrative Law" in Grant Huscroft and Michael Taggart, eds., Inside and Outside Canadian Administrative Law: Essays in Honour of David Mullan (Toronto: University of Toronto Press, 2006) at 50.

${ }^{96}$ Katrina Miriam Wyman, "The Independence of Administrative Tribunals in an Era of Ever Expansive Judicial Independence" (2001) 14 Can. J. Admin. L. \& Prac. 61 at 117 (eC) ["Independence"]. But see Frank Falzon, "The Integrated Administrative Tribunal" (2006) 19 Can. J. Admin. L. \& Prac. 239 at 249 (eC).

${ }_{97}$ Ocean Port, supra note 94, Valente v. R., [1985] 2 S.C.R. 673.

${ }^{98}$ Sossin, "Speaking Truth" supra note 92 at 53.

99 Katrina Miriam Wyman, "Appointments to Adjudicative Tribunals: Politics and the Courts" (1999) 57 U.T. Fac. L. Rev. 101 at ๆ 36 (QL) [“Appointments”].
} 
of social policy. They are required to decide Charter ${ }^{100}$ and other constitutional issues that arise in cases that are before them. ${ }^{101}$ Administrative tribunals have been called the 'front-line embodiments of the Rule of Law." ${ }^{102}$ In addition, the "due process explosion"103 has meant that tribunals are subject to more and more procedural fairness obligations. ${ }^{104}$

Others argue that fundamental differences between the function of courts and administrative tribunals negate the necessity for more stringent safeguards of independence, including constitutional protection. ${ }^{105}$ Administrative tribunals do not perform the constitutional role that the courts $\mathrm{do}^{106}$ and are not called upon to regularly adjudicate Charter issues. ${ }^{107}$ Moreover, even adjudicative tribunals play a policy role ${ }^{108}$ and are situated within the executive branch for that reason. As such, they must be able to engage in their mandate more flexibly. ${ }^{109}$ Finally, administrative tribunals are intended to be more efficient and costeffective and less formal than the courts and should thus not be encumbered with the same due process or independence requirements.

${ }^{100}$ Canadian Charter of Rights and Freedoms, Part I of the Constitution Act, 1982, being Schedule B to the Canada Act 1982 (U.K.), 1982, c. 11.

${ }^{101}$ David Mullan, "Tribunals Imitating Courts - Foolish Flattery or Sound Policy? (2005) 28

Dalhouse L.J. 1 at 12.

102 The Honourable Madam Justice Beverley McLachlin, "The Roles of Administrative Tribunals and Courts in Maintaining the Rule of Law" (1999) 12 Can. J. Admin. L. \& Prac. 171 at 189 (eC).

103 Mullan, supra note 101 at 3.

104 Ibid. (Noting, but not supporting, the trend).

${ }^{105}$ Wyman, "Independence" supra note 96 at 63.

106 J. Paul Lordon, "The Independence of Administrative Tribunals: Checking Out the Elephant" (1996) 45 U.N.B.L.J. 123 at 124.

${ }_{107}$ Wyman, "Independence" supra note 96 at 117.

${ }^{108}$ As Wyman notes, judicial recognition of the policy role of tribunals has led the courts to accept procedures, such as full board meetings, that would not be tolerated in the courts. Wyman, "Appointments" supra note 99 at para. 35. See Consolidated-Bathurst Packaging Ltd. v. International Woodworkers of America, Local 2-69, [1990] 1 S.C.R. 282, 1990 CarswellOnt 821 (eC).

${ }^{109}$ Wyman, "Appointments" supra note 99 at para. 36. 
For the purposes of this analysis, I do not think it is necessary to take a position on merits of the "judicialization" of administrative tribunals. It is sufficient to note that to the extent that tribunals play an increasingly judicial role, and are thus held to higher standards of independence and impartiality, arguments for judicial diversity apply to administrative tribunals with equal force. Aside from the similarities between courts and tribunals, however, administrative decisionmaking itself bears particular qualities that further justify greater diversity. ${ }^{110}$ As such, the argument for diversity on administrative tribunals is not solely dependent upon their judicialization or any analogy to the function of the courts.

\section{Legitimacy and Administrative Adjudication}

The similarity between the functions and roles of courts and tribunals means that democratic legitimacy arguments to support judicial diversity are also applicable to administrative tribunals. While administrative tribunals and adjudicators do not have the status and visibility that courts and judges have, they nonetheless constitute an influential arm of the state that can have an impact on a wide range or issues relating to individuals' basic rights and interests and to their relationship with the state. ${ }^{111}$ Administrative decisions can also have far-reaching policy implications. In addition, the need for equality of access is also applicable - administrative tribunals should no more constitute a "privileged fraternity" than the courts.

\footnotetext{
${ }^{110}$ See Chapter II below at 32 .

${ }^{111}$ In a 1991 speech to the Canadian Council of Administrative Tribunals, then Chief Justice Antonio Lamer said: " ... the impact of administrative tribunals on the lives of individual Canadians is great and likely surpasses the direct impact of the judiciary ...." quoted in Falzon, supra note 99 at 249.
} 
Certain features of administrative decision-making render the legitimacy arguments made with respect to courts more persuasive in the context of administrative tribunals. One such feature of administrative decision-making is the primacy of procedural fairness and the appearance of fairness to the validity of administrative decisions. Because tribunals are not courts and because they are exercising statutory authority, a significant aspect of administrative law is the development of appropriate safeguards to protect the procedural fairness of those who are subject to the decisions of administrative bodies. ${ }^{112}$ Procedural safeguards that have developed over time include the right to a hearing before an unbiased decision-maker, ${ }^{113}$ and the duty to give reasons for a decision. ${ }^{114}$ Decisions of administrative tribunals are often reviewed solely on procedural grounds and without reference to the substance of those decisions.

The appearance of fairness is thus a key aspect of administrative justice and one in which diversity can have a significant impact. Diversity is seen as contributing to the legitimacy of the courts in that the decisions rendered by a diverse institution are more likely to inspire public confidence than those rendered by an exclusive, homogenous one. Empirical research in the U.K. suggests that the presence of racialized adjudicators on administrative tribunals enhances perceptions of fairness among racialized groups that are most likely to perceive unfairness in the process. ${ }^{115}$ On a purely formal level, the composition

\footnotetext{
${ }_{112}$ Mullan, supra note 101 at 2 (discussing the "due process explosion.")

${ }_{114}^{113}$ Singh v. Canada (Minister of Employment and Immigration), [1985] 1 S.C.R. 177.

${ }^{114}$ Baker, supra note 5.

${ }^{115}$ Hazel Genn, Ben Lever and Lauren Gray et al., "Tribunals for diverse users" (DCA Research Series January 2006) online: Department for Constitutional Affairs $<$ http://www.dca.gov.uk/research/2006/01 2006.pdf> at 227 ["the Genn Study"]. For a further discussion of the Genn study, see Part IV below.
} 
of administrative tribunals can thus influence the degree to which the decisions of those tribunals are viewed as fair and legitimate.

Administrative decision-making is also characterized, for the most part, by an absence of appeal. While the decisions of administrative tribunals are subject to review by the courts, in many cases, such review is in practice unlikely because of the time and cost involved in pursuing an application for judicial review. Moreover, courts exercise varying degrees of deference toward the decisions of administrative tribunals based on factors such as their respective expertise, the nature of the issue, and the availability of appeal. This means that especially when deference is required, the decisions of administrative tribunals will largely go unchallenged. According to France Houle, of the 20,000 to 25,000 decisions rendered by the Refugee Protection Division of the Immigration and Refugee Board per year, only one to two percent (approximately 300 to 600 decisions per year) are accepted for review and heard by the Federal Court. ${ }^{116}$ This low rate of judicial review is not because of the outstanding quality of the decisions, but because of access to justice issues. ${ }^{117}$ Houle argues that the near impossibility of reviewing administrative decisions creates a power imbalance and increases the likelihood of error, especially in "mass-adjudication tribunals" like the IRB. ${ }^{118}$ The inaccessibility of appeal is thus another feature of administrative decision-making that makes it important that the decisions of

\footnotetext{
${ }^{116}$ France Houle, "Constructing the Fourth Branch of Government for Administrative Tribunals" (2007) 37 S.C.L.R. (2d) 117 at 133.

117 Ibid.

118 Ibid.
} 
administrative tribunals be seen as fair and the institutions be viewed as legitimate.

Therefore, in my view, to the extent that administrative tribunals increasingly exercise court-like functions, arguments to support diversity based on the legitimacy of the judiciary are equally applicable to adjudicative administrative tribunals. Further, certain unique aspects of administrative tribunals, namely, the primacy of perceptions of fairness and the lack of appeal, render the institutional rationale even more convincing in the administrative context. In Chapter II, I will examine other features of administrative decisionmaking that further justify the extension of arguments for judicial diversity to administrative based on the individual rationale.

Although legitimacy and public confidence in the judiciary and administrative justice system are valid concerns, I suggested at the outset that such formal arguments render an incomplete account of the justifications for greater diversity. In my view, if calls for diversity are based solely on the institutional rationale, they will remain constrained and will conceal the transformative potential of diversity. As such, I will now turn to examining the individual rationale in greater detail. 


\section{CHAPTER II - EXPERIENCE AND PERSPECTIVE: THE INDIVIDUAL RATIONALE FOR THE DIVERSITY OF LEGAL DECISION MAKERS}

\section{A. Diversity Challenges Traditional Conceptions of Adjudication}

Unlike the "institutional" rationale for diversity that has been discussed in the previous section, the "individual" rationale highlights the potential substantive impact of diverse judges and adjudicators on legal decision-making. In brief, the individual rationale for increased diversity is based on the view that judges from marginalized groups, such as racialized persons, will bring different, previouslyexcluded perspectives to the task of adjudication. ${ }^{119}$ In my view, while the objective of a diverse judiciary is seen as worthy in principle, when based upon the formal, legitimacy-related concerns articulated above, any substantive justification causes greater apprehension. ${ }^{120}$ One reason for this uneasiness could be that a substantive rationale is interpreted as implying that racialized judges would decide cases in a certain way. Another source of discomfort arises from the view that it is improper for judges to bring any perspective, let alone novel ones, to legal decision-making. This is evidenced by the charges of bias against women and racialized judges and adjudicators that will be described further in this section.

Despite the discomfort with substantive arguments for diversity, the individual side of the equation is necessary to reveal the true value of diversity, which is more than a numerical reflection of the population. Unless and until we

\footnotetext{
${ }^{119}$ See e.g. Ifill, "Judging the Judges, supra note 9, Ifill, "Racial Diversity, supra note 66, Sylvia Lazos Vargas, "Does a Diverse Judiciary Attain a Rule of Law that is Inclusive? What Grutter v. Bollinger Has to Say About Diversity on the Bench" (2005) 10 Mich. J. Race \& L. 101 at 114 [Grutter and Diversity].

${ }_{120}$ Ifill, "Judging the Judges" supra note 9 at 98 . See also, Ifill "Racial Diversity" supra note 66 at 409.
} 
are prepared to recognize and advocate a substantive rationale for diversity, the transformative capacity of diversity cannot be realized. As a result, in this section, I will attempt to demystify how diversity can have an impact on legal decision-making and why this should be embraced, rather than feared.

\section{The Limitations of Traditional Conceptions of The Role of the Judge}

The argument that judges from diverse backgrounds, because of their different experiences, will bring new and previously excluded perspectives to the bench is a familiar, but not uncontroversial one. Earlier in this paper, I noted that the independence and impartiality required of judges makes it more challenging to envisage judges as representatives. Similarly, calls for a more diverse judiciary based on the argument that judges from traditionally-excluded groups have different perspectives are perceived to challenge the principles of objectivity, neutrality and impartiality that have long been seen as essential to the judicial role.

A number of misconceptions about the role of judges fuel the general wariness toward any substantive rationale for increased judicial diversity. The first is a formalistic view of the judge's role as limited to a mechanical application of existing laws and rules to various factual situations. The presumption is that the law is a set of objective and neutral rules and principles that can be discovered, an "autonomous entity with a coherence of its own." ${ }^{121}$ Chief Justice McLachlin has referred to this as the "myth of legal certainty"122 - the belief that

\footnotetext{
121 Devlin et al. supra note 66 at 740.

122 The Right Honourable Beverley McLachlin, P.C., "Judging in a Democratic State" (Remarks, Sixth Templeton Lecture on Democracy, University of Manitoba, June 2004) online: Supreme Court of Canada <http://www.scc-csc.gc.ca/court-cour/ju/spe-dis/bm04-06-03-eng.asp > ["Judging in a Democratic State"].
} 
in any given case, a "right" answer can be arrived at through the application of logic and reasoning. As Devlin notes, "[a] central theme of idealism is that judicial choice is constrained and harnessed by the power of legal rationality." ${ }^{123}$ According to formalist conceptions of the law, a judge's perspective is irrelevant because cases can and must be decided solely on the law. This disregards the reality of legal indeterminacy, ${ }^{124}$ the fact that existing rules and norms do not necessarily produce particular results.

A related aspect of the idealist conception of the law is a view of judging as distinct from and untainted by politics. ${ }^{125}$ According to this view, judges do not make the law, but are limited to applying legal norms enacted by the legislature. Their involvement in the formulation of public policy should therefore be limited. This view overlooks the fact that judges must apply justice in novel situations or circumstances that were not contemplated by the legislature or addressed by precedents. ${ }^{126}$ Chief Justice McLachlin has acknowledged that "a degree of judicial law-making is inevitable." ${ }^{127}$ The advent of the Charter has transformed the role of judges in Canada and has led to a greater recognition of the inherently political, policy-making nature of this role. ${ }^{128}$

The complexity of legal decision-making in a pluralistic society renders it illusory to believe that a judge can be led to the "right" answer by an exercise of

${ }^{123}$ Devlin et al., supra note 66 at 743.

124 Chief Justice McLachlin, "Modern Society" supra note 74.

${ }^{125}$ Devlin et al., supra note 66 at 740.

126 Jeremy Webber, "The Adjudication of Contested Social Values: Implications of Attitudinal Bias for the Appointment of Judges" in Ontario Law Reform Commission, ed. Appointing Judges:

Philosophy, Politics and Practice (Toronto: Ontario Law Reform Commission, 1991) at 4.

${ }^{127}$ Chief Justice McLachlin, "Modern Society" supra note 74.

128 Jamie Cameron, "Toward a Theory of Responsible Justice" in Canadian Institute for the Administration of Justice" in M. Morrissette, W. MacLauchlan \& M. Ouelette, eds., Open Justice (Montreal: Editions Thémis, 1994) 135 at 149, cited in Devlin et al., supra note 75 at 739. 
rationality. Making judgments about the laws and rules to be applied to particular facts requires judges to consider the norms and values that shape those rules. In addition, the interpretation and application of legal rules necessarily involves some idea of how they fit into a normative system as a whole. ${ }^{129}$ As critical race theorists and feminist legal scholars have forcefully argued, the very neutrality of the rules and principles that are to be applied is questionable. Those purportedly neutral rules "are merely accounts driven by the perspective of the group empowered to impose its rules on the larger society." ${ }^{130}$ It is more likely that in cases where the answers are not clear or when competing values are at stake that the experience and perspective of the judge will take on greater importance. As a result, a judge's perspective does enter into the picture and can affect how they view and decide cases.

The recognition that legal decision-making invokes values, and that in a multicultural, pluralistic society such values can be contested highlights the limits of traditional conceptions of the role of judges. It is not because of bias that judges' personal backgrounds influence their decisions but "because many cases cannot be decided by reasoning from shared premises of fact and value."131 Thus, Judge Posner points to U.S. research that demonstrates that Roman Catholic judges are 11 percent more likely to rule against gay rights than Protestant judges and 25 percent more likely to do so than Jewish judges, while

\footnotetext{
${ }^{129}$ Webber, supra note 126 at 4.

130 Ifill, "Racial Diversity" supra note 66 at 440 . Ifill notes that racial and gender narratives have informed and shaped the construction and interpretation of legal principles such as merit, discrimination, colourblindness, property, parental autonomy, individual rights, and reasonableness. Ibid.

${ }^{131}$ Posner, supra note 88 at 120.
} 
Black and Hispanic judges are 20 percent more likely than whites to rule in favour of gay rights. ${ }^{132}$ In Judge Posner's view, in a heterogeneous society, a diverse judiciary is essential because of the unbridgeable conflicts that arise when value judgments are concerned:

When because of cultural heterogeneity judicial decisions depend more on who is making them than on an objective decisionmaking procedure, it is better to make the judiciary representative than to seek a spurious neutrality by homogenizing it. ${ }^{133}$

Another aspect of legal decision-making that formalist and idealist conceptions of the law fail to take into account is the large degree of discretion that judges and adjudicators possess. Legal principles and precedents do not always dictate the result that should be reached in a particular case. Chief Justice McLachlin summarized this reality succinctly when she noted: "indeterminacy gives way to judicial discretion."134 Judges must choose and interpret the applicable legal principles. While some cases can be resolved by an application of existing rules and precedents to facts, a large portion of cases cannot.

In addition to the indeterminacy of legal norms is the wide discretion that judges possess with respect to the finding and interpretation of facts and evidence. Even the most straight-forward cases can involve numerous discretionary assessments, such as the admissibility of evidence, that must be made before a final decision can be made. In making findings of fact, the judge's discretion is virtually unbound. They choose whom and what to believe. ${ }^{135} \mathrm{~A}$

\footnotetext{
132 Ibid.

133 Ibid.

${ }_{134}^{134}$ McLachlin, "Role of Judge" supra note 74.

135 Ifill, "Racial Diversity" supra note 66 at 475.
} 
study based on interviews with Canadian appellate court judges concludes that discretion is pervasive and even "astounding." ${ }^{136}$ Many of these discretionary judgments involve instincts, assumptions about human behaviour and other intangible qualities. As a result, even given the same facts and principles, different judges, irrespective of their backgrounds, will arrive at different decisions.

Judging has never been simply about finding the correct answer through an application of existing legal rules. Indeed, the common law is the product of judges deciding particular cases and adjusting legal principles on an ongoing basis. The Charter and the pluralism of contemporary society have further altered the judge's role in the articulation of law and policy. Despite the evolving nature of judging, however, the idealist conception of the law and the correspondingly limited view of the judge's role continue to have appeal and act as a powerful force against a more representative judiciary. ${ }^{137}$

\section{Administrative Adjudication}

To the extent that the role of administrative adjudicators is akin to that of judges, they are subject to similar preconceptions about the limits of their role. In addition, the requirement that administrative tribunals not exceed their statutory jurisdiction further reinforces perceptions about the constraints on administrative decision-making. As a result, calls for greater diversity on administrative tribunals will encounter resistance similar to that based on limited conceptions of the judge's role.

\footnotetext{
${ }^{136}$ Greene et al., Final Appeal: Decision-making in Canadian Courts of Appeal (Toronto: James Lorimer, 1998), cited in Devlin et al. supra note 75 at 792.

137 Ibid. at 745 .
} 


\section{a. Complexity}

As observed in Part I of this paper, administrative tribunals occupy a unique position in the constitutional division of powers because they fall under the executive branch but perform a function that is increasingly similar to that of the courts. While administrative tribunals might not receive as much attention as the courts do, they are nonetheless important institutions of the state that make social policy decisions that "profoundly influence" the lives of many. ${ }^{138}$ Cases and disputes that are heard by administrative tribunals can also implicate contested values and public policy considerations. It is thus as illusory to assume that administrative adjudicators are limited to applying existing legislation and regulations in a straightforward or mechanical manner. One example is human rights tribunals, which have to address complex issues such as the scope of basic rights or the duty to accommodate that require a delicate balancing of different policy objectives.

The case of Baker v. Canada (Minister of Citizenship and Immigration) ${ }^{139}$ provides a good example of the complexity of administrative decision-making, although in that case the decision-maker was a front-line immigration officer and not a tribunal. In Baker, the issue was the officer's exercise of Ministerial discretion in determining whether the applicant should have been granted admission to Canada on humanitarian and compassionate grounds. In a farreaching decision, the Supreme Court held that the exercise of this discretion

\footnotetext{
${ }^{138}$ Canadian Bar Association, Report of the Canadian Bar Association Task Force on the Independence of Federal Administrative Tribunals and Agencies in Canada (Ottawa: Canadian Bar Association, 1990) at 4, quoted in Wyman, "Appointments" supra note 99 at para. 36.

${ }^{139}$ Baker, supra note 6.
} 
had to be consistent not only with the limits of the statute, but also with the fundamental values of Canadian society and the principles of the Charter. ${ }^{140}$ Despite the considerable discretion afforded by the regulations, the decision was found to be unreasonable because of the officer's failure to take into consideration values such as the best interests of the applicant's children. ${ }^{141}$

This case demonstrates that the decisions that administrative adjudicators make on a daily basis can be value-laden, complex and can involve competing policy interests. ${ }^{142}$ Just as legal principles do not dictate results in court, the statutory provisions and regulations that tribunals are required to apply do not necessarily point to clear answers. This is especially true where the statute confers the decision-making body with broad discretion.

\section{b. Discretion}

Like judges, administrative adjudicators possess significant discretion with respect to determinations such as credibility and admissibility of evidence. They are also less restrained by procedural and evidentiary rules than the courts, allowing for greater flexibility in fact-finding. As a result, decisions by administrative tribunals will likely often come down to an adjudicator's interpretation of the facts and which witnesses they found credible - matters that are largely discretionary. In their study of the refugee determination system, François Crépeau and Delphine Nakache describe the complexity of that process. It is informed by values and principles derived from the Charter as well

\footnotetext{
${ }^{140} \mathrm{Ibid}$. at para. 56 .

141 Ibid.at para. 65.

142 The decision-maker in Baker, supra was a front-line immigration officer and not an administrative tribunal. Administrative adjudicators, such as those on the IRB must also make similarly complex decisions that implicate competing values.
} 
as by international standards. The number of claims is daunting, the consequences of an incorrect decision are far-reaching, and, due to the lack of hard evidence, credibility is central to the inquiry. ${ }^{143}$

In addition to the discretion that judges possess, administrative decisionmaking frequently involves the exercise of discretion that is accorded by statute, as was the case in Baker. Discretion in the administrative context refers to decisions in which the law does not dictate a specific outcome or when a decision-maker has a range of options within the boundaries imposed by statute. ${ }^{144}$ Discretionary decisions are generally subject to review for limited grounds, reflecting the view that where the statute confers broad choices on administrative decision-makers, courts should not interfere lightly with those decisions. ${ }^{145}$

It is the discretionary aspect of administrative decision-making that gives greater force to arguments for diversity in the context of administrative tribunals. In Baker, supra, the Supreme Court held that discretion must be exercised in a manner consistent with statutory limits, the principles of the rule of law, the principles of administrative law, the fundamental values of Canadian society, and the principles of the Charter. In Baker, supra, the decision was unreasonable because the administrator was not "alert, alive and sensitive" to the best interests of the applicant's children and the decision was inconsistent with the values

\footnotetext{
${ }^{143}$ François Crépeau \& Delphine Nakache, "Critical Spaces in the Canadian Refugee Determination System: 1989-2002" (2008) 20 Int'I J. Refugee. L. 50 at 57 . Regarding the vagaries of credibility assessments in refugee determinations, see Jenni Milbank, "'The Ring of Truth': A Case Study of Credibility Assessments in Particular Social Group Refugee Determinations" (2009) 21 Int'l J. Refugee. L. 1.

${ }^{144}$ Baker, supra note 5 at 52.

$145 \mathrm{Ibid}$. at para. 53.
} 
underlying the grant of discretion. ${ }^{146}$ The administrator was also found to be biased based on the notes of another immigration officer who drew conclusions based on stereotypes about the applicant's history of mental illness, employment history and the number of children she had. ${ }^{147}$ Of particular note is the paragraph of the decision in which Justice L'Heureux-Dubé applies a contextual analysis that looks more broadly at the role of immigration officers. She finds that because they make decisions of great importance to the individuals affected by them and to Canada as a country, they require a "special sensitivity" that includes "a recognition of diversity, an understanding of others, and an openness to difference." 148

The "special sensitivity" required of immigration officers should also apply to administrative adjudicators who adjudicate issues of similar importance and who come into contact with a diverse clientele. This special sensitivity militates for greater diversity. As will be demonstrated further in this Part, an adjudicator's experience impacts significantly on their perspectives, which in turn influences how they will view and interpret facts and legal principles. Moreover, discretion is "sponge-like, it absorbs values, assumptions and preferences to which it is exposed." ${ }^{149}$ In areas such as immigration, social benefits, human rights and landlord and tenant disputes, administrative adjudicators deal with an extremely diverse clientele and come into contact with a broad range of racialized and other

\footnotetext{
${ }^{146} \mathrm{Ibid}$. at para. 75 .

${ }_{148}^{147} \mathrm{Ibid}$. at para. 48.

$148 \mathrm{Ibid}$. at para. 47.

${ }^{149}$ France Houle, "L'arret Baker: le role des regles administratives dans la reception du droit international des droits de la personne en droit interne" (2002) 28 Queen's L.J. 511 at 516, cited in Lorne Sossin, "From Neutrality to Compassion: the Place of Civil Service Values and Legal Norms in the Exercise of Administrative Discretion" (2005) 55 U. Toronto L.J. 427 at 438-39 (WL) ["Neutrality to Compassion"].
} 
marginalized groups. They must be "alert, alive and sensitive" to factors such as the circumstances of the individuals who appear before them, as well as to the values underlying the grant of discretion that they exercise. Otherwise, the discretion will not be exercised in accordance with the principles articulated in Baker.

\section{c. Policy Role}

Unlike the courts, administrative tribunals have a recognized policy role.

This is another reason why diversity might in fact be more important among administrative adjudicators than judges. The role of administrative tribunals is "part law, part policy." ${ }^{150}$ Even when they perform a largely adjudicative function, they decide cases within a statutory context, applying public policy as set out in the legislation and incrementally developing new policy. ${ }^{151}$ The public policy mandate of tribunals requires not only that they be accountable to the individuals who appear before them, but that they be attuned to broader social changes: ${ }^{152}$

In complex policy areas that are characterized by high and emotive content like immigration, politicians, policy analysts, and the general public are less inclined to engage in policy debates which might challenge the broader framework of accepted social values. As a result, decisions that may have major public policy implications can be made by default by bureaucrats exercising their powers of discretion. These decisions, or policy outcomes, can have serious unintended consequences for the broader society. ${ }^{153}$

\footnotetext{
${ }^{150}$ Rosalie S. Abella, "Canadian Administrative Tribunals: Toward Judicialization or Dejudicialization?" (1989) 2 Can. J. Admin. L. \& Prac." 1 at 2.

${ }^{151}$ Wyman, "Appointments" supra note 99 at 34.

152 Ibid.

${ }^{153}$ Genevieve Bouchard \& Barbara Wake Carroll, "Policy-Making and Administrative Discretion: The Case of Immigration in Canada" (2002) 45 Can. Pub. Ad. 239 at 239-40, quoted in Lorne Sossin, "Neutrality to Compassion" supra note 149 at 438.
} 
Diversity is thus important to administrative tribunals so that they can thoroughly and properly assess the social changes and "social needs"154 that are the backdrop for the decisions that they render.

\section{Impartiality As An Absence of Perspective}

Calls for a more diverse or representative judiciary are also resisted on the ground that such representation is counter to the principle of impartiality. According to this view, it should not matter what race or gender a judge is because he/she is required to judge cases impartially. ${ }^{155}$ Indeed, it is thought that impartiality would be impaired if characteristics such as race were considered relevant when appointing judges. ${ }^{156}$ Judges must shed all preconceptions and identifications to discover and apply the relevant law, and must treat everyone the same without regard to race, class, gender or other personal characteristics. ${ }^{157}$ Chief Justice McLachlin has called this view of impartiality the "myth of the blank mind."158 As she asserts: "[t]o insist that the judge purge all preconceptions and values from the mind is to place an impossible burden on the judge and induce impossible expectations in the public." ${ }^{159}$ It is doubtful whether such impartiality would even be desirable because the public expects judges to rely upon their knowledge, experience and

${ }^{154}$ Consolidated Bathurst, supra note 108 at 565.

155 See e.g. F.L. Morton, "Judicial Appointments in Post-Charter Canada" in Kate Malleson and Peter H. Russell eds., Appointing Judges in an Age of Judicial Power (Toronto: University of Toronto Press, 2006) at 72.

${ }_{157}^{156}$ Nedelsky, "Relational Autonomy" supra note 8 at 113.

${ }^{157}$ Richard Devlin, "We Can't Go On Together with Suspicious Minds: Judicial Bias and Racialized Perspective in R. v. R.D.S." (1995) 18 Dalhousie L.J. 408 at 423 ["Suspicious Minds"]. For example, during his confirmation hearing, Justice Clarence Thomas stated that, as a judge, he would "strip down, like a runner." Ifill, "Racial Diversity" supra note 66 at 432.

${ }^{158}$ Chief Justice McLachlin, "Judging in a Democratic State" supra note 122.

159 Ibid. 
"sense of justice" 160 to interpret laws, evaluate credibility, impose sentences, and to determine constitutionality. The Canadian Judicial Council's Commentaries on Judicial Conduct state that the duty of impartiality:

does not mean that a judge does not, or cannot bring to the bench many existing sympathies, antipathies or attitudes. There is no human being who is not the product of every social experience, every process of education, and every human contact with those with whom we share the planet. Indeed, even if it were possible, a judge free of this heritage of past experience would probably lack the very qualities of humanity required of a judge. ${ }^{16}$

Nonetheless, the "blank slate" conception of impartiality remains an obstacle to calls for increased diversity on courts and tribunals. This is evidenced in the difficulty that some litigants have in accepting women or racialized judges and adjudicators. By virtue of their race or gender alone, such "outsider" judges and adjudicators are seen as incapable of being impartial, as that quality is traditionally conceived. Women and racialized judges and adjudicators have been subject to recusal motions or charges of bias simply on the basis of their gender or race, or on the basis of a shared background with a litigant. In Commonwealth of Pennsylvania v. Local Union 5442, ${ }^{162}$ Judge Leon Higginbotham of the federal court in Pennsylvania was faced with a recusal motion in a case in which African American union members alleged that they were discriminated against by their union. The motion was based on the fact that Judge Higginbotham was African American and that he had used the term "we" in a speech before a group of African Americans. ${ }^{163}$ In her article, Ifill cites other

\footnotetext{
${ }^{160}$ Ifill, "Racial Diversity" supra note 66 at 432, quoting Justice Benjamin Cardozo.

${ }^{161}$ R.D.S., supra note at para. 119 quoting Canadian Judicial Council, Commentaries on Judicial Conduct, (1991) at 12.

162 Commonwealth of Pennsylvania v. Local Union 5442, 388 F. Supp. 155 (E.D. Pa. 1974).

163 Ifill, "Judging the Judges" supra note 9 at 114-15. See also, Blank v. Sullivan \& Cromwell, 418

F. Supp. 1 (S.D.N.Y. 1975) in which the defendant law firm sought to have African American
} 
cases in which parties have sought to remove African American judges as well as comments made on the nomination and appointment of racialized judges to demonstrate the "continuing and widespread discomfort with minority judges and impartiality." 164

Closer to home, in her article, "The Fiction of Judicial Impartiality," Justice Maryka Omatsu ${ }^{165}$ describes numerous examples of parties seeking the removal of administrative adjudicators on the basis of their gender or racial origin. ${ }^{166}$ The difficulty of seeing "outsider" judges and adjudicators as impartial has not lessened with time or with increased diversity. Very recently, Faisal Bhabha, a Vice-Chair of the Human Rights Tribunal of Ontario, was subject to an allegation of bias on the basis that he colluded with respondent's counsel in the case. ${ }^{167}$ The allegations appear to have been based solely on the applicant's assumption that Vice-Chair Bhabha and respondent's counsel were of the same ethnic origin:

[I]t appears that the adjudicator is the "Babar" of the Tribunal, agreeing with the "Raj" or king of the tribunal where the applicant, who is not part of any royal caste, is ignored as an untouchable. Please see definitions of Raj and Barbar and caste.

When the names of the adjudicator and chair of the Human Rights Legal Support Center [sic] are derived from a discriminatory caste system, there appears to be an acceptance and propagation of discrimination where the applicant who is underprivileged and complaining about discrimination is ignored by the Babar and Raj who, according to the caste system, only acknowledge themselves and ignore those below their caste. ${ }^{168}$

These examples demonstrate that a diverse or representative judiciary continues to be seen as somehow incompatible with traditional notions of

Judge Constance Baker Motley recuse herself in a gender discrimination case on the basis of her gender, race, and background as a civil rights lawyer.

164 Ifill, "Judging the Judges" supra note 9 at 118-19.

${ }^{165}$ Ontario Court of Justice.

${ }^{166}$ Maryka Omatsu, "The Fiction of Judicial Impartiality" (1997) 9 Can. J. W \& L. 1 at 9-12.

${ }^{167}$ Christianson v. Ontario (Information and Privacy Commissioner), 2009 HRTO 424.

$168 \mathrm{lbid}$. at para. 10. "Raj" is apparently referring to Raj Anand, Chair of the Board of Directors of the Human Rights Legal Support Centre. 
impartiality. The traditional conception of impartiality as an absence of perspective, however, is inaccurate and deficient. This "blank slate" conception of impartiality is unattainable as long as it is human beings who are making legal judgments. Moreover, once impartiality is conceived of in this limited manner, it appears that persons from previously under-represented groups such as racialized persons cannot be impartial.

\section{a. Competing Views of Impartiality: R. v. R.D.S.}

Perhaps indicative of the strength of traditional conceptions of impartiality and the perceived incompatibility of diversity with such notions is the fact that the first case in Canada finding an apprehension of racial bias was against an African Canadian judge, Corinne Sparks. ${ }^{169}$ The case, R. v. R.D.S.,${ }^{170}$ involved an altercation that occurred between a White police officer and the accused, a Black youth. To summarize the facts briefly, the accused, R.D.S., arrived at the scene as the police officer was arresting another black youth, R.D.S.'s cousin. The police officer alleged that R.D.S. ran into him with a bicycle, pushed him and yelled at him. R.D.S. claimed that the police officer threatened to arrest him and put him in a chokehold. As a result of the conflicting accounts, the key issue was the credibility of the police officer and R.D.S. Judge Sparks acquitted R.D.S. and in doing so, made the following remarks:

The Crown says, well, why would the officer say that events occurred the way in which he has relayed them to the Court this morning. I'm not saying that the constable has misled the Court, although police officers have been known to do that in the past. And I'm not saying that the officer overreacted, but certainly

\footnotetext{
${ }^{169}$ Devlin remarks that "... surely it is significant that the first Canadian case where there is a finding of an apprehension of racial bias is in relation to statements made by a Black judge." Devlin, "Suspicious Minds" supra note 157 at 423.

${ }^{170}$ R.D.S., supra note 5.
} 
police officers do overreact, particularly when they're dealing with non-white groups. That, to me, indicates a state of mind right there that is questionable.

I believe that probably the situation in this particular case is the case of a young police officer who overreacted. And I do accept the evidence of Mr. S. that he was told to shut up or he would be under arrest. That seems to be in keeping with the prevalent attitude of the day."

Those comments resulted in an appeal on the basis of both actual and apparent bias on the basis of race. Both the decision of the appeal judge ${ }^{172}$ and the Court of Appeal ${ }^{173}$ reflect traditional conceptions of impartiality and a formalist conception of the role of the judge. Glube C.J., referring to the two paragraphs quoted above, found that the statements led to a reasonable apprehension of bias. ${ }^{174}$ She went on to state: "judges must be extremely careful to avoid expressing views which do not form part of the evidence."175 Similarly, the majority of the Court of Appeal found that "the unfortunate use of these generalizations, by the Youth Court judge" would lead to a reasonable person to conclude that she had based her findings of credibility at least partially on the basis of matters not in evidence. ${ }^{176}$ In other words, the judge's general knowledge about the social context in which the incident occurred, that is, the pervasiveness of racism in Canadian society and a propensity of White police officers to overreact when dealing with non-White youth, was not relevant. Although "judges routinely and uncontroversially make reference to issues of

\footnotetext{
171 Ibid. at para. 4.

172 R. v. S.(R.D.), 1995 CarswellNS 608 (S.C.), Glube C.J. (orally) (eC).

${ }_{174}$ R. v. S. (R.D.) 145 N.S.R. (2d) 284, 102 C.C.C. (3d) 233, 1995 CarswellNS 245 (C.A.) (eC).

${ }_{175}^{174}$ R.D.S., (Glube C.J.) supra note 172 at 25.

175 Ibid. at para. 24.

${ }^{176}$ R.D.S., (C.A.), supra note 173 at 42.
} 
common knowledge"177 in Judge Sparks' case, this led to an apprehension of bias.

The separate reasons of a fractured Supreme Court further demonstrate very differing views about impartiality and about the proper role of the judge. While a majority of six judges found no reasonable apprehension of bias, three judges found that there was. ${ }^{178}$ Major J., for the dissent, found that Judge Sparks' conclusions were not based on the evidence and that she was not entitled to rely upon her life experience in evaluating the credibility of the police officer: "[l]ife experience is not a substitute for evidence."179 Even the judges who agreed in the result disputed the propriety of Judge Sparks' remarks. Cory J. found that the remarks were "unfortunate and unnecessary" 180 and "worrisome and come very close to the line." ${ }^{181}$ By contrast, Justices McLachlin and L'Heureux-Dubé found that Judge Sparks had engaged in a proper consideration of the facts in evidence and the social context in which the incident occurred and that her remarks reflected a particular understanding of that context. They concluded that Judge Sparks was justified in taking into consideration the "wellknown racial dynamics" that can exist between police officers and racialized groups and was engaging in contextualized judging. ${ }^{182}$

\footnotetext{
${ }_{177}^{178}$ Devlin, "Suspicious Minds" supra note 157 at 430.

${ }^{178}$ R.D.S., supra note 5. The reasons of McLachlin. and L'Heureux-Dubé JJ. were concurred with by Gonthier and LaForest JJ., while Cory J. wrote separate reasons, which were concurred with by lacobucci J. Major J. wrote the reasons for the dissent, which included Lamer C.J.C. and Sopinka J.

179 Ibid. at para. 13

${ }^{180} \mathrm{Ibid}$. at para. 158.

$181 \mathrm{lbid}$. at para. 152.

$182 \mathrm{Ibid}$. at paras. 57 and 59.
} 
R.D.S. and the cases described earlier illustrate that White, male judges are assumed to be impartial and are not required to demonstrate their impartiality. On the other hand, judges from racialized groups are seen as incapable of impartiality, especially when dealing with race or a racialized litigant. ${ }^{183}$ The presumed correlation between the dominant White majority and impartiality equates "whiteness" with an absence of perspective or perpetuates the view that a majority perspective is a neutral one, while all others are not. ${ }^{184}$ This view of impartiality also fails to acknowledge that the legal system itself has largely been shaped by white males who have created the "objective" rules that judges and adjudicators are required to apply. As a result, it is not only the presumption of impartiality but also the assumed neutrality of those rules that is open to question. ${ }^{185}$

The bias cases also betray an uneasiness about racialized persons in the role of judge or adjudicator. It is for this reason that I argue that broadly-stated commitments to diversity do not extend to the substantive impact that diversity could potentially have. Judicial diversity is desirable in principle, indeed, it is only proper in a pluralistic, democratic society. However, the prospect that decisions rendered by racialized judges or adjudicators could reflect "different" perspectives, or at least new or previously unheard ones, is unsettling. Difference itself, however, is relative. ${ }^{186}$ It is only because certain dominant

\footnotetext{
${ }^{183}$ The same arguments have been made with respect to women judges when dealing with gender-related issues such as sexual harassment.

184 Martha Minow, "Stripped Down Like a Runner or Enriched By Experience: Bias and Impartiality of Judges and Jurors" (1992) 33 Wm. \& Mary L. Rev. 1201.

${ }^{185}$ Moloney Smith, supra note 83 at 188.

${ }^{186}$ Rackley, supra note 12 at 87; Minow, “Justice Engendered” supra note 67 at 13.
} 
perspectives have been normalized that racialized perspectives are perceived as "different." The potential for racialized judges and adjudicators to have a substantive impact on legal decision-making challenges traditional conceptions of adjudication but should not be seen as a threat to impartiality. Rather, as will be demonstrated in Part III, it should be seen as an opportunity to reconceive and enhance impartiality in a manner that is more reflective of our social reality.

\section{B. Experience Impacts Legal Decision-Making}

As alluded to in the previous section, the reality of legal decision-making is that not only do judges and adjudicators from racialized groups come to the hearing and deciding of cases with particular perspectives and life experiences, but that all legal decision-makers do. The study of Canadian appeal courts found that "[w]hat determines a particular judge's decision is the interplay of his or her personality, background, values, and legal education." 187

Judges themselves acknowledge the impact of their own perspectives.

Justice Benjamin Cardozo described this phenomenon as follows:

There is in each of us a stream of tendency, whether you choose to call it philosophy or not, which gives coherence and direction to thought and action. Judges cannot escape that current any more than other mortals. All their lives, forces which they do not recognize and cannot name, have been tugging at them - inherited instincts, traditional beliefs, acquired convictions; and the resultant is an outlook on life, a conception of social needs.... In this mental background every problem finds its setting. We may try to see things as objectively as we please. None the less, we can never see them with any eyes except our own. ${ }^{188}$

Similarly, in a recent interview, Justice Ginsburg of the U.S.S.C. has stated:

Yes, women bring a different life experience to the table. All of our differences make the conference better. That I'm a woman, that's part of it, that I'm Jewish,

\footnotetext{
${ }^{187}$ Greene, Final Appeal, supra note 136 at 2, quoted in Devlin et al., supra note 75 at 792.

${ }^{188}$ Benjamin N. Cardozo, The Nature of the Judicial Process (1921) at 12-13 and 167, quoted by Justices McLachlin and L'Heureux-Dubé in R.D.S., supra note 5 at para. 34 .
} 
that's part of it, that I grew up in Brooklyn, N.Y., and I sent to summer camp in the Adirondacks, all these things are part of me. ${ }^{189}$

More specifically, Judge Edward Chen ${ }^{190}$ has stated "[s]imply put, a judge's life experiences affect the willingness to credit testimony or understand the human impact of legal rules upon which the judge must decide."191

While these statements demonstrate that the impact of experience on judging is undeniable, the potential impact of racialized judges' perspectives on their decision-making raises concerns about bias or lack of impartiality. ${ }^{192}$ As argued above, however, this apprehension is based upon the misconception that non-racialized judges do not have particular perspectives. Diversity is essential because all judges and adjudicators bring to the task of judging their various backgrounds, values and experiences. It is therefore important that the various influences not be limited to those of a narrow, privileged group.

This raises the question of how a judge or adjudicator's experiences and perspectives will impact their decision-making, particularly when those experiences differ from those of the dominant group. In a well-known address

${ }^{189}$ Emily Bazelon, "The Place of Women on the Court" New York Times (12 July 2009), online: The New York Times < http://www.nytimes.com/2009/07/12/magazine/12ginsburgt.html?scp=2\&sq=ginsburg\&st=Search $>$.

${ }^{190}$ Magistrate Judge, Northern District of California.

191 The Honourable Edward M. Chen, "The Judiciary, Diversity and Justice for All" (2003) 10 Asian L.J. 127 at 138.

192 The controversy over the nomination of Judge Sonia Sotomayor to the United States Supreme Court is an example. Judge Sotomayor's remark that "Whether born from experience or inherent physiological or cultural differences... our gender and national origins may and will make a difference in our judging" has elicited criticism. See: Charlie Savage, "A Judge's View of Judging Is on the Record" The New York Times (15 May 2009), online: The New York Times http://www.nytimes.com/2009/05/15/us/15judge.html?. 
"Will Women Judges Really Make a Difference?" ${ }^{193}$ Madam Justice Bertha Wilson waded into this debate from a gender perspective:

If women lawyers and women judges through their differing perspectives on life can bring a new humanity to bear on the decision-making process, perhaps they will make a difference. Perhaps they will succeed in infusing the law with an understanding of what it means to be fully human. ${ }^{194}$

While Madam Justice Wilson's answer is tempered with a "perhaps," her American counterpart, Justice Ginsburg has said that women judges would compel men to "look at life differently."195

Admittedly, the impact of difference on adjudication is an area that is fraught with difficulty because it raises a couple of particularly thorny issues, and it is those issues that further impede the acceptance of a substantive rationale for diversity. One such issue is the misapprehension that calls for diversity are based on the conviction that racialized (or women) judges and adjudicators will decide cases in a particular way. A second, related issue is that the argument is seen to imply that racialized persons have a single, unified perspective. ${ }^{196}$ Both of these concerns, however, result from an over-simplification of the "individual" rationale for diversity. In this section, I will attempt to explain how background and experience affect a judge or adjudicator's perspective and therefore his/her decision-making. In doing so, I hope to buttress the individual or substantive rationale for diversity.

\footnotetext{
${ }^{193}$ Madam Justice Bertha Wilson, "Will Women Judges Really Make A Difference?" (1990) 28 Osgoode Hall L.J. 507 (originally presented at the Fourth Annual Barbara Betchermann Lecture, Osgoode Hall Law School, 8 February 1990.)

194 lbid. at 522.

195 Ifill, "Racial Diversity" supra note 66 at 448 quoting Justice Ginsburg.

${ }^{196}$ For a further discussion of essentialism see below at 57.
} 


\section{The Experience of Marginalization Affects Perspective}

The argument that judges and adjudicators from racialized groups will bring different perspectives to legal decision-making is based in part upon the view that the experience of marginalization itself leads to a distinctive perspective on issues of law. ${ }^{197}$ Representation of racialized persons and other historically excluded groups is thus necessary in order to give voice to that perspective ${ }^{198}$ which cannot be represented by others. ${ }^{199}$ Some have argued that the distinct perspective afforded by the experience of marginalization enables racialized persons $^{200}$ to have a "deeper insight into the human condition of vulnerability."201 Similarly, Melissa Williams relies upon John Rawls' social contract theory, which posits that greater insight into the justice of a measure can be gained if we evaluate it from the perspective of disadvantaged members of society. ${ }^{202}$

The distinctive perspective of marginalized groups, such as racialized persons, is often thought to encompass a capacity for empathy. Errol Mendes, for example, suggests that diversity on the judiciary would increase the potential for contextualized decision-making in which "mercy and equity" would take on greater importance. ${ }^{203}$ Chief Justice McLachlin has stated that a judge "must be capable of empathy." 204 Empathy was one of the characteristics that U.S.

\footnotetext{
${ }^{197}$ Devlin et al. supra note 75 at 792.

198 Ibid. (summarizing the argument).

${ }^{199}$ Williams, supra note 19 at 140.

200 This could potentially apply to other marginalized groups as well.

${ }^{201}$ Errol Mendes "'Promoting Heterogeneity of the Judicial Mind: Minority and Gender Representation in the Canadian Judiciary" in Ontario Law Reform Commission, Appointing Judges supra note 126, 91at 97.

${ }^{202}$ Williams, supra note 19 at 140 . The difference is that according to her "voice" model of representation, others cannot speak for marginalized groups as those groups would speak for themselves.

${ }^{203}$ Mendes, supra note 201 at 97.

${ }^{204}$ Chief Justice McLachlin, "Judging” supra note 122.
} 
President Barack Obama identified in his search for the next Supreme Court judge. ${ }^{205}$ There is no doubt that empathy is a valuable quality in judges and adjudicators to the extent that it enables them to look beyond their own situation and to understand the circumstances from the position of the individual appearing before them. ${ }^{206}$

While it is problematic to suggest that persons from racialized and other marginalized groups are more capable of empathy or to equate identity with particular traits or even a certain "world view," the experience of marginalization will have some impact upon how individuals view legal issues. Sylvia Lazos Vargas provides a persuasive explanation as to why racialized persons, and potentially other marginalized groups, have distinct perspectives. Lazos Vargas identifies a cleavage between what she calls majority and minority epistemologies. Majorities and minorities acquire distinct epistemologies because their differing social positions influence what they experience, how they interpret that experience and how they construct knowledge. Lazos Vargas argues that it is this social experience, rather than minority status or identity, that creates a distinct epistemology. ${ }^{207}$ While she acknowledges the differences among and between minorities, Lazos Vargas nonetheless argues that "what

\footnotetext{
${ }^{205}$ President Obama's stated objective of appointing a Supreme Court judge with a capacity for empathy was subject to some criticism in the media. See Dan Froomkin, "Obama's empathy litmus test" The Washington Post (4 May 2009), online: The Washington Post <http://voices.washingtonpost.com/white-house-watch/obamas-empathy-litmus-test.html>. ${ }^{206}$ Geneviève Cartier, "Reconceiving Discretion: From Discretion as Power to Discretion as Dialogue" (SJD Thesis, University of Toronto, 2004) [unpublished] at 270-71 ["Reconceiving Discretion"].

${ }^{207}$ Sylvia Lazos Vargas, "Democracy and Inclusion: Reconceptualizing the Role of the Judge in a Pluralist Polity" (1999) 58 Md. L. Rev. 150 at 187-88 (WL) [“Democracy and Inclusion"].
} 
makes a minority experience distinct and a minority epistemology possible is its quality of "otherness:"

Even though majorities and minorities share a common culture and many common social experiences, minorities' continuous encounters with discrimination, stereotypes, and privilege cause them to experience social life from a radically different vantage point. It is this commonality of social experiences that gives rise to a different minority epistemology.... ${ }^{208}$

Racialized groups, by virtue of the multiple and common alienating experiences to which they are subject, share a distinct social space, thus producing a self-conscious collective of individuals who "share a common sense of how they interpret the social dynamics that affect them."209 Similarly, Melissa Williams argues that members of marginalized groups share the experience of cultural and structural obstacles that non-members do not, including the experience of group-based stereotypes. At the same time, she recognizes that group members experience marginalization differently and will have divergent interests. ${ }^{210}$

The differences between majority and minority epistemologies manifest themselves in sharply diverging views on many fundamental moral and political issues. As Ifill states: "the breadth of the racial divide in values, interests, and perspectives is often wide and deep." ${ }^{211}$ U.S. scholars theorize that because Black and White Americans still lead largely segregated lives and because their different experiences have strong economic and social implications, they develop

\footnotetext{
208 Ibid. at 195.

209 Ibid. at 194-95.

${ }^{210}$ Williams, supra note 19 at 18.

${ }^{211}$ Ifill, "Racial Diversity" supra note 66 at 431 . She further notes that "[w]hile studies show that blacks continue to work and play in a 'black' social milieu, whites are the least likely to engage in social experiences outside their own racial group." Ibid.
} 
very divergent moral attitudes. ${ }^{212}$ For example, Joy Milligan uses results from the General Social Survey ${ }^{213}$ to show that Blacks and Whites have widely diverging views on issues such as capital punishment (42.9\% of Blacks in favour, $69.9 \%$ Whites in favour), the right to end one's life if suffering from an incurable illness (33\% of Blacks in favour, as compared to $63 \%$ of Whites), and government assistance to the poor ( $89.8 \%$ of Blacks said the government spends "too little" while $60.6 \%$ of Whites said too little). ${ }^{214}$ In various studies cited by Milligan, researchers have attempted to control for other variables such as religion, education, and income level. However, even those factors had different effects on Black and White views. ${ }^{215}$ Other studies show a deep divide between Blacks and Whites with respect to the justice system. According to one such study, 83 percent of White judges surveyed felt that Black litigants were treated fairly in the justice system, but only 18 percent of Black judges agreed. ${ }^{216}$ Black and White Americans have vastly different views about the fairness of the criminal justice system. ${ }^{217}$

While the studies referred to above undoubtedly have their limitations, they suggest that values, beliefs and attitudes about a wide range of issues can vary significantly by race. In the case of Canada, where societal factors present

\footnotetext{
212 Joy Milligan, "Pluralism in America: Why Judicial Diversity Improves Legal Decisions About Political Morality" (2006), 81 N.Y.U.L. Rev. 1206, 1221 (Milligan examines the degree of segregation in neighbourhoods, schools, religious organizations and workplaces.

${ }^{213}$ The General Social Survey is a national survey conducted every two years by the National Opinion Research Center at the University of Chicago. It asks the general public for their views on a broad range of issues. Interestingly, on each question Blacks and Whites were at either end of the spectrum with Latinos and Asian Pacific Americans falling in between.

${ }^{214}$ Milligan, supra note 212 at $1223-24$.

$215 \mathrm{Ibid}$. at 1225-29.

${ }^{216}$ Ifill, "Racial Diversity" supra note 66 at 436.

${ }^{217}$ Ibid. at 425.
} 
in the U.S., such as segregation, are less pronounced, the divide may not be as wide. The studies cited earlier about the economic impact of race suggest that similar tendencies might exist. One other possibility that the studies suggest is a difference in perspective from those who experience life in Canada as immigrants as opposed to those who are born in Canada. ${ }^{218}$ Those born in Canada can take for granted their entitlement to stay and to have access to a wide range of social services. By contrast, immigrants, in addition to feeling like outsiders, must live with the insecurity of having to establish their right to remain in the country and to access the same social services. The Greene Study of appellate court judges observed that "[e]thnicity was not mentioned by a single judge as a cause of differences about the law...."219 The study nonetheless speculated that this was because the judges were from "more long-established" ethnic groups and that there could be more differences of opinion if more appellate court judges were from recent immigrant groups who had "lived through the experience of becoming accepted as Canadian and everything that entails[.]"220

To argue that the experience of marginalization leads racialized persons to develop a distinct epistemology is not to claim that there is a single, racialized perspective. Canadian society is characterized by an exceptional range of diversity among those who have traditionally been identified as "visible minorities." The different racial groups have been subject to different experiences and varying degrees of subordination and marginalization.

${ }^{218}$ Statistics Canada, Ethnic Diversity Survey, supra note 40.

${ }^{219}$ Greene study, supra note 136, cited in Devlin et al., supra note 75 at 803.

220 Ibid. 
Individuals within particular groups will have different views and perspectives. Additional characteristics such as gender, income level, disability or sexual orientation further affect those experiences. Moreover, as numerous scholars have argued, identity itself is fluid. ${ }^{221}$ As a result, identity and perspective are not necessarily correlated. The argument that marginalization leads to the development of a distinct epistemology should not be interpreted as implying a common perspective. Nonetheless, the experience of marginalization and subordination by racialized groups can give rise to different values and perspectives. Because all judges and adjudicators are influenced by their values and perspectives, the perspectives of racialized judges and adjudicators would in turn shape the way in which they view and interpret different facts and legal principles.

\section{Legal Decision-Makers Will Respond Differently to Alternative Narratives}

One of the ways in which values, perspectives and beliefs can have an impact is on how judges and adjudicators respond to narratives. A judge or adjudicator's response to narratives is significant because good advocacy is often seen, and indeed taught, as the construction of a persuasive narrative that will convince a judge and/or jury of the rectitude of one's case. Lawyers thus spend an inordinate amount of time on developing a compelling "story" that is internally consistent and that would appeal to a judge or jury's common sense, as well as their sense of justice.

${ }^{221}$ Devlin et al. supra note 75 at 803; Lawrence, "Reflections" supra note 18 at 12. 
All narratives, however, do not start off on the same footing. As Steven Winter argues, "[w]hat is true for reason is true for eloquence; both must find receptive ground if they are to do any work at all.... Persuasion, in other words, is constrained by what the audience already believes."222 What judges and adjudicators believe, and what they will understand, is affected by their own circumstances. As a result, certain facts might seem inconsistent with their common sense. One common example is the inability to understand why a person would not report sexual or racial harassment in the workplace. The fear of losing one's job might not seem credible to someone, such as a judge, who has never experienced that type of insecurity.

Although the judiciary has become somewhat more diverse than it was in the past, it remains a largely homogenous institution populated by White men from middle-to-upper class backgrounds. The perspectives of this narrow crosssection of society have thus dominated legal discourse and adjudication to the exclusion of those of traditionally underrepresented groups such as women and racialized persons. Judges, like all humans, respond to familiar narratives. ${ }^{223}$ Dominant narratives are so pervasive that they have become the truth. ${ }^{224}$ By contrast, alternative narratives that do not correspond to those truths are more difficult to make heard. Accounts that are inconsistent with dominant understandings are easily and readily rejected as incredible:

\footnotetext{
${ }^{222}$ Steven L. Winter, A Clearing in the Forest: Law, Life, and Mind (Chicago: University of Chicago Press, 2001) at 320.

${ }^{223}$ Ifill, "Racial Diversity" supra note 66 at 444.

224 "[S]ociety's dominant narratives will seem unexceptionable and 'true' - demanding no particular improvement or expansion." Delgado and Stefancic, "Norms and Narratives: Can Judges Avoid Serious Moral Error?" (1991) 69 Tex. L. Rev. 1929 at 1957, quoted in Ifill, "Racial Diversity" supra note 66 at 444.
} 
To be credible, witnesses' narratives need to be close enough to culturally available stories to be recognizable as something that could happen but possessed of enough distinguishing information to be recognizable as the narrative of a distinct event. ${ }^{225}$

As a result, individuals from marginalized groups have more difficulty in making the details of their own social situations apparent to those, such as judges or jurors, who have very different life experiences. ${ }^{226}$ Their reality simply does not coincide with culturally available narratives. The impact of dominant narratives can be seen in the assault trial of the Los Angeles police officers accused of beating Rodney King. The defence was able to portray King as a threat to the officers, thereby justifying their use of force and resulting in their acquittal. The jury, from the White, affluent suburb where the trial was held, was convinced by a decontextualized, deconstructed analysis of the videotape that made King appear as the aggressor. Despite the clearly excessive use of force depicted on the videotape, the narrative of self-defence against a dangerous, drugged-out, Black criminal resonated more strongly with them. ${ }^{227}$

Ifill suggests that judges might be more susceptible to an unquestioning acceptance of dominant narratives than jurors, as they are faced day after day with overloaded dockets and defendants from particular racial groups. They may be more likely to fall back on stereotypes and culturally-embedded assumptions to simplify their tasks. ${ }^{228}$ This could also be true for administrative adjudicators such as those on the Immigration and Refugee Board or Landlord Tenant Board who have full dockets, and overwhelming numbers of litigants, often

\footnotetext{
${ }^{225}$ Kim Lane Scheppele, "Manners of Imagining the Real" (1995) L. \& Soc. Inquiry 995 at 1006.

${ }^{226} \mathrm{Ibid}$. at 1011.

227 Ibid. at 1019.

${ }^{228}$ Ifill, "Racial Diversity" supra note 66 at 445.
} 
unrepresented, from particular groups. The notes of the immigration officer in Baker, supra were problematic precisely because they reflected particular stereotypes of "single mothers," women of colour and mental illness. ${ }^{229}$

As increasing numbers of women, racialized persons and other underrepresented groups enter the legal profession, the judiciary, and tribunals, outsider narratives challenge long-accepted versions of the truth by presenting alternative conceptions of reality. However, outsider narratives are not accorded the same legitimacy that dominant narratives receive. ${ }^{230}$ In the case of R.D.S., it is possible to detect two dominant narratives at work at different levels. The first dominant narrative could be described as follows: as police officers have no motive to lie, their accounts should generally be viewed as more credible than that of the accused. The second narrative is that in order to render an impartial, unbiased decision, judges should look only at the evidence and not to their own experience or to social context. Both of these narratives reflect long-accepted beliefs about the justice system. The comments of Judge Sparks challenged both narratives with an outsider perspective that was not well-received and indeed, resulted in an allegation of bias. With respect to the first dominant narrative, she noted that police officers "have been known to" mislead the court. ${ }^{231}$ This reference to her own experience and to context challenged generally held views about impartiality. It is thus evident that alternative racial narratives reveal different and significant ways of reconceiving well-established

\footnotetext{
${ }^{229}$ See discussion above at 47.

230 Ifill, "Racial Diversity" supra note 66 at 441.

${ }^{231}$ R.D.S., supra note 5 at para. 4.
} 
principles by challenging the realities on which those principles are based. ${ }^{232}$ This is important not only to the outcome of individual cases but also to the evolution of the law because existing legal rules and principles are based upon long-accepted and legitimized narratives. ${ }^{233}$ This is not to say that one group's narratives should be accepted over that of another, but that "[b]y ensuring that competing narratives interact in legal decision-making... we decrease the opportunity for bias and for one set of narratives to dominate judicial decisionmaking." 234

One example of alternative narratives challenging existing ones emerged from my interviews of adjudicators on the HRTO, which are summarized in greater detail in Chapter IV of this thesis. The adjudicators that I interviewed spoke of differing views on the facts in a particular case, Abdullah $v$. Thames Valley District School Board. ${ }^{235}$ In that case, the complainant was an adult ESL student who had emigrated from Egypt a couple of years prior to the incident in question. The personal respondent was an ESL teacher at the school that the complainant was attending. They became involved in a heated dispute over the respondent's suspicion that the complainant was cheating. In the course of the dispute, the personal respondent said: "I am sick and tired of immigrants crying discrimination when they don't get what they want."236

One of the issues before the adjudicator was whether or not the above remark constituted discrimination on the basis of race, place of origin, ethnic

\footnotetext{
${ }^{232}$ Ifill, "Racial Diversity" supra note 66 at 440.

233 Ibid. at 441.

234 Ibid. at 442.

${ }^{235}$ Abdallah v. Thames Valley District School Board, 2008 HRTO 230.

${ }^{236}$ Ibid. at para. 53.
} 
origin and/or citizenship. Vice-Chair Chadha found the remark discriminatory because it was a derogatory generalization based on negative stereotyping about immigrants. ${ }^{237}$ In doing so, she rejected the respondents' arguments that the remark was a response to a stressful and confrontational interaction. ${ }^{238}$ She referred to further contextual factors, such as the fact that the personal respondent was an ESL teacher and that the institution's purpose was to provide language instruction to newcomers to Canada, ${ }^{239}$ as well as a further exchange between the teacher and student about who is or is not a Canadian. ${ }^{240}$ ViceChair Chadha stated: "The remark is evocative of the idea that "immigrants" are outsiders and reinforces the notion that they are not legitimate members of Canadian society because they perpetuate fraud in order to get what they want." ${ }^{241}$

According to the adjudicators that I interviewed, the case elicited some discussion and debate among tribunal members. Some adjudicators initially viewed the comment as a thoughtless remark made in the middle of a heated argument with an aggressive student, and did not think it constituted discrimination. Concerns about freedom of expression were also raised. Other adjudicators pointed to additional factors such as the further discussion about who is a "Canadian" and the respondent's position as an ESL teacher, and found the statement discriminatory. ${ }^{242}$ Behind these two differing interpretations of the

\footnotetext{
${ }^{237}$ Ibid. at para. 62.

${ }^{238}$ Ibid. at para. 59.

$239 \mathrm{Ibid}$. at para. 60.

$240 \mathrm{Ibid}$. at para. 65.

241 Ibid. at para. 66.

${ }^{242}$ Notes of Interview with Michael Gottheil, Chair of the HRTO, dated April 8, 2009 ("Gottheil Interview"; on file with author), Notes of interview with E, a Vice-Chair of the HRTO, dated May 4,
} 
events, it is possible to glean two distinct narratives. A dominant narrative could view the remarks are isolated, excusable under the circumstances, and likely exceptional. The alternative narrative might view such remarks as exclusionary, injurious, and in all likelihood, pervasive. Different life experiences could lead opposing narratives to resonate with an adjudicator. An adjudicator who, perhaps as an immigrant or racialized person, has been subject to similar remarks could have a greater sensitivity toward the demeaning effect of such remarks and of constantly being made to feel unwelcome in one's home country. An adjudicator who has never experienced this type of exclusion could more easily dismiss those types of comments and therefore question their harmfulness. Moreover, depending on the relevant narrative, different contextual elements could be seen as important. One adjudicator might view as important the fact that the remark took place during a heated exchange with a difficult student. Another might view as more significant the fact that the respondent was an ESL teacher, someone who regularly comes into contact with new immigrants and who plays a role in helping such individuals adjust to their adopted country.

Different backgrounds and experiences can have a substantive impact on legal decision-making in that a judge or adjudicator's personal experiences can lead them to find certain narratives more convincing than others. The perspectives and narratives of marginalized groups can challenge dominant narratives that have come to be accepted as true. The inclusion of more diverse

2009 ("E Interview"; on file with author), Notes of interview with G, a Vice-Chair of the HRTO, dated June 1, 2009 ("G Interview"; on file with author) (speaking generally about the discussions and not necessarily their personal views.) 
judges and adjudicators, such as racialized persons, is thus necessary in order to avoid unconscious institutional biases.

\section{Explanations Based In Cognitive Psychology}

The tendency for judges and adjudicators to view matters in a particular light because of their beliefs, backgrounds and experiences makes intuitive sense. However, the strength of traditional conceptions of judging, such as the "myth of the blank mind," makes it necessary to find ways to explain this tendency. Some legal scholars have looked to cognitive theory as a means of better understanding the workings of the human mind and, therefore, the process of making legal judgments. ${ }^{243}$ According to Steven Winter, cognitive theory makes explicit the unconscious criteria and cognitive operations that structure and constitute our judgment. ${ }^{244}$ Cognitive theory posits that our cognitive processes are limited by our experiences because of the process of "categorization," or the internalization of concepts and categories as a result of our experiences. As the simplest concepts incorporate normative assumptions about proper social functions and appropriate behaviours, ${ }^{245}$ it is inevitable that more complex and value-laden concepts do as well. These assumptions will actively shape legal decision-making because they are embedded in how judges think and "cannot be dispensed with by any simple act of will or mere political desire." ${ }^{246}$ Winter's cognitive theory analysis thus provides insight into the inability of judges to separate themselves from their personal experiences.

\footnotetext{
${ }^{243}$ Winter, supra note 222 at 313.

244 Ibid. at xiii.

${ }^{245}$ Winter gives the examples of the words "mother" or "park." Ibid. at 316.

${ }^{246}$ Ibid. at 13.
} 
As noted above, the different experiences of majorities and minorities lead them to possess distinct epistemologies. Lazos Vargas further identifies a process of "epistemological privileging" that leads judges to favour the dominant or majority epistemology. ${ }^{247}$ She points to a number of reasons for this tendency. First, despite the lofty principles of objectivity, neutrality and impartiality, judges are and remain socially situated actors. ${ }^{248}$ They possess their own ideology of unstated assumptions based on their social experiences, which are influenced by their gender, race, and class. In difficult cases, their own "common sense," which is socially positioned, will determine the context that they find relevant. ${ }^{249}$ Second, judges possess a substantial degree of discretion, even when their decisions might appear to be limited by precedent and general principles of law. ${ }^{250}$ Judges retain the ability to frame the discussion, interpret precedent, and choose which public policy concerns matter. Judges can thus, consciously or unconsciously, mould applicable principles to arrive at a result that accords with their own epistemology. Moreover, the outcome, even when it is based on ideological choices, will appear to be neutral and reasoned. ${ }^{251}$

Finally, Jennifer Nedelsky relies upon neurologist Antonio Damasio's concept of "somatic markers" to explain certain examples of seemingly incomprehensible lapses in judgment on the part of judges. ${ }^{252}$ According to

\footnotetext{
${ }^{247}$ Lazos Vargas, "Democracy and Inclusion" supra note 207 at 196.

248 Ibid. at 197, Ifill, "Racial Diversity" supra note 66 at 436.

249 Lazos Vargas, “Democracy and Inclusion” supra note 207 at 198.

250 lbid. at 199.

251 Ibid.

252 Jennifer Nedelsky, "Embodied Diversity and the Challenges to Law" in Beiner \& Nedelsky, eds., supra note 8, 229 at 238-39 ["Embodied"]. One example that Nedelsky points to is the case of the B.C. judge who sentenced a man convicted of "sexual interference" with a three-year old girl that he was baby-sitting to probation on the basis that the girl was "sexually aggressive."
} 
Damasio's theory, effective reasoning requires somatic markers, which are emotional responses or "gut feelings" that people learn to associate with certain images through experience. Somatic markers are the product of experience, education and culture and help sort through what would otherwise be an overwhelming range of possible actions. Effective reasoning is thus the result of both cognitive processes and processes usually seen as "emotional" acting in concert. ${ }^{253}$ Nedelsky characterizes the lapses in judgment that she describes as "failures of affect" ${ }^{254}$ as opposed to failures of reason. In the case of a B.C. judge who sentenced a man to probation for sexual interference with a three-year old girl in his care, the judge clearly identified more closely with the perpetrator than with the victim. ${ }^{255}$ Because somatic markers are so rooted in one's experience, it is difficult to develop or shift them, especially because for the most part, we are not conscious of them. ${ }^{256}$

In other words, the operation of complex cognitive processes, often at a subconscious or unconscious level, can lead us to respond, or not respond, to given facts, circumstances or issues. Judge Chen, noting that he has heard more than one colleague remark that a particular witness or litigant reminded them of a friend or relative, states that "[i]t should not be surprising that one might tend to have an initial visceral, perhaps unconscious, sympathetic reaction to someone who strikes a chord of familiarity." ${ }^{257}$ The influence of our particular

"Exactly What the Judge Said to the Convicted Sex Offender," The Vancouver Sun (1 December 1989), A17, cited in Ibid. at 238.

${ }^{253}$ Nedelsky, "Embodied Diversity" supra note 255 at 237-38.

254 Ibid.

255 The judge found the little girl to have been "sexually aggressive." Ibid.

256 Ibid. at 243.

${ }^{257}$ Chen, supra note 191 at 137. 
experiences is powerful but is all the more so because it is invisible. The unconscious categorization that we instinctively engage in, the privilege accorded to the dominant epistemology, and the absence of somatic markers all reflect deeply-embedded thought processes. These in turn contribute to a volume of unstated assumptions that influence the way judges and adjudicators think and, consequently, the way they decide.

It is more difficult, although not impossible, to challenge or even to expose those assumptions when the judiciary is unrepresentative. Judges and adjudicators who are surrounded by sameness as opposed to difference will tend to reinforce their existing beliefs. The risk is that an unrepresentative judiciary or tribunal will result in an invisible, institutional bias. ${ }^{258}$ The insights gained from the above analyses of cognitive processes support the view that racialized groups, and other subordinated groups, will indeed have different perspectives from the majority, based on the distinct ways in which they experience life.

\section{Empirical Evidence of the Impact of Diversity on Legal Decision- Making}

Efforts to advocate for judicial diversity have resulted in various empirical studies about the impact of gender and race on judicial decision-making. A recent empirical study of the impact of gender and party of appointment on decisions of the Ontario Court of Appeal suggests that in certain areas of the law, the presence of women judges on appellate panels affects the outcome of

${ }^{258}$ Moloney Smith, supra note 83 at 202. 
cases. ${ }^{259}$ The study found the existence of a "dampening effect" on appeal panels that were of mixed gender. Taking one example, in criminal cases in which the accused was able to assert a Charter claim to obtain an acquittal, mixed-gender panels affirmed 81 percent of the time, while all-male panels affirmed 70 percent of the time. More than one female judges sitting at the same time affirmed the dismissal 82 percent of the time, while all-male panels affirmed 72 percent of the time. Interestingly, when male judges sat on a panel with a single female judge, they affirmed the dismissal 86 percent of the time. ${ }^{260}$ These and other findings led its authors to observe that on certain issues, the voting of male judges appeared to have been influenced considerably by the presence of a single female colleague. ${ }^{261}$ A recent U.S. study found both a "gender effect" and a "panel effect" in sex discrimination cases. In other words, women judges were more likely to rule in favour of the rights litigant and men were more likely to rule in favour of the rights litigant when they served on a panel with a woman. ${ }^{262}$

There is also evidence that diversity in appellate court panels leads to better decision-making processes. U.S. studies have shown that judges on diverse panels were more likely to debate a wider range of considerations in reaching their judgments than judges on homogenous panels. A diverse panel

\footnotetext{
259 James Stribopoulos \& Moin A. Yahya, "Does A Judge's Party Of Appointment Or Gender Matter To Case Outcomes? An Empirical Study Of The Court Of Appeal For Ontario" (2007) 45 Osgoode Hall L.J. 315 at 354 [the "Stribopoulos Study"].

260 Ibid. at 360.

261 Ibid. at 361.

${ }^{262}$ See Christina L. Boyd, Lee Epstein and Andrew D. Martin, "Untangling the Causal Effects of Sex on Judging" (2007) at 20-21 [unpublished] online: Northwestern University School of Law $<$ http://epstein.law.northwestern.edu/research/genderjudging.pdf. The study, however, found no gender effect on all other areas of the law. Ibid.
} 
was more likely to render a decision in closer line with what the law requires. ${ }^{263}$ Many studies, however, have been inconclusive. ${ }^{264}$ This is likely due to the wide range of additional factors that can affect judges' decisions, such as professional background, socio-economic class and political views, not to mention the facts of the particular case. Empirical studies have also tended to focus on outcomes in a simplistic equation that leaves little room for the subtle ways in which identity can impact on legal reasoning and decision-making. ${ }^{265}$ In his article, Josh Hsu looks to the language employed by Asian American judges to identify the impact of their race not solely on the outcome of the case but on their reasoning. ${ }^{266} \mathrm{He}$ argues that certain Asian American judges have demonstrated an understanding and empathy for immigrant litigants absent in other immigration cases. ${ }^{267}$ This includes an awareness of the harsh consequences of deportation, which those judges see as akin to a criminal penalty while case law has traditionally couched deportation in milder terms of returning an individual to their home country. Hsu thus argues that diversity is valuable even when it cannot be measured in terms of case outcomes because it gives voice to alternative conceptions of legal principles that challenge existing rhetoric. ${ }^{268}$

As a result, it is not only through case outcomes that the impact of diversity on adjudication should be assessed. The argument that diversity will

\footnotetext{
${ }^{263}$ Charles M. Cameron and Craig P. Cummings, "Diversity and Judicial Decision-Making: Evidence from Affirmative Action Cases in Federal Courts of Appeal 1971-1999" (2003) Col. L. Rev. cited in Dame Hale, "Appointment and Removal" supra note 91 at 2.

264 Josh Hsu, "Asian American Judges: Identity, Their Narratives, and Diversity on the Bench" (2006) 11 Asian Pac. Am. L.J. 92 at 107.

265 Ibid. at 101.

${ }^{266}$ Ibid.

267 Ibid. at 111

${ }^{268}$ Ibid..
} 
have a substantive impact on legal decision-making does not necessarily mean that results are the only relevant consideration. The process of including marginalized perspectives, hearing and considering previously excluded narratives, and exposing long-held assumptions, to the extent that this is revealed in judicial reasoning, are as valuable for their effect on the particular case at hand as for the long-term development of the law.

The empirical research of the impact of diversity is useful for another perhaps unintended purpose. There might be a reason why the research relating to appellate panels is more fruitful when inquiring into the impact of diversity on judging than an analysis of the decisions of individual judges. This points to a further benefit of diversity that even the individual rationale does not sufficiently acknowledge: the value of diversity is not simply the impact of the different perspectives that individual judges bring to the cases that they hear but the influence of diverse judges, their experiences and their perspectives on the court or tribunal on which they serve. This influence will be examined in the next part of this thesis. 


\section{CHAPTER III - STRUCTURAL IMPARTIALITY: AN INTEGRATIVE CONCEPTION OF DIVERSITY}

\section{A. Reconceiving Impartiality as Incorporating Multiple Perspectives}

Common conceptions of the role of judges and adjudicators, along with traditional views of impartiality, have made it more difficult to see "outsider" judges and adjudicators as objective and impartial. The above analysis of the influence of experience on judgment demonstrates, however, that it is not only "outsider" judges who possess particular perspectives. As socially-situated actors, all judges are subject to the influences of their backgrounds, experiences, beliefs and values. The only difference is that the dominant perspective that has traditionally informed adjudication has largely gone unnoticed or has been typified as neutral. ${ }^{269}$

The problem is thus not that the inclusion of outsider judges is incompatible with the principles of objectivity, neutrality and impartiality, but that those concepts, as currently conceived, do not accurately capture how judgments are made. I further argue that it is not the rationale for diversity that is weakened by traditional conceptions of judging and impartiality, but the converse. Diverse judges and adjudicators, by bringing and expressing alternative perspectives, challenge long-accepted assumptions, both with respect to substantive legal standards and the process of legal decision-making. As Erica Rackley puts it, "diversity throws a spotlight onto conventional understandings of the judge and judging, challenging the listener to leave the security of the familiar

269 Ibid. at 113-14. 
and to embark on new adjudicative adventures." ${ }^{270}$ It thus becomes necessary to reconceive impartiality and the role of judges and adjudicators in a manner that is cognizant of difference and more consistent with the reality of legal decisionmaking.

Does the individual rationale fully explain the potential impact of racialized judges? As the studies on appellate adjudication suggest, I will argue in this Chapter that the true value of diversity lies in the impact of racialized judges and adjudicators on the institutions of legal decision-making.

\section{Judging with an Enlarged Mentality: Arendt's Theory of Judgment}

The work of Hannah Arendt, based on her interpretation of Kant's theory of aesthetic judgment, provides a theory of judgment that helps overcome some of the limitations of traditional conceptions of judging and impartiality. According to Arendt, judgment falls between "truth claims" which can be proven objectively, and the expression of mere subjective preference, which cannot make a claim of validity for anyone else. When exercising the faculty of judgment, one cannot compel agreement but can only persuade or "woo the consent of everyone else in the hope of coming to an agreement with him." ${ }^{271}$ Judgments thus involve claims to "subjective universality." depends on the capacity for "enlarged thought" which enables one to make a judgment freely, unbound by one's private idiosyncracies or interests.

\footnotetext{
${ }^{270}$ Rackley, "Judicial Diversity" supra note 12 at 87.

${ }^{271}$ Arendt, quoting Kant's Critique of Judgment \$19, cited in Nedelsky, "Relational Autonomy" supra note 8 at 107.

${ }^{272}$ Ibid.
} 
It is the manner in which this enlarged mentality is achieved that is particularly relevant to the exercise of judgment in a diverse society. According to Arendt's reading of Kant, the enlarged mentality is to be attained by imagining the judgment from the standpoints of others. ${ }^{273}$ When making a judgment, we want to be able to persuade others that the judgment is valid; in order to do so, we imagine how others would view the judgment and what they might say. This does not mean, however, simply deferring to or substituting the perspectives of others for our own, nor does it mean to search for a consensus. ${ }^{274}$ The ability to take the perspectives of others is essential to liberating ourselves from our "subjective private conditions" in order to transcend our own individual limitations. It is only by doing so that a judgment can be truly autonomous and impartial:

You see that impartiality is obtained by taking the viewpoints of others into account; impartiality is not the result of some higher standpoint that would then settle the dispute by being altogether above the melée. ${ }^{275}$

Arendt's theory of judgment gives rise to a notion of impartiality that is more situated than suspended. As argued above, judges inevitably bring to the task of judging their backgrounds, experiences and sensibilities, which then shape their perspectives. According to Arendt's conception of judgment, they can refer to their own perspectives but must also take those of others into account. This would help to achieve an impartiality that is attentive rather than blind to difference. The conception of impartiality that emerges from Arendt's theory of judgment is thus rooted in a recognition of the plurality of society and

\footnotetext{
${ }^{273}$ While Kant envisaged this dialogue to "woo the consent" of others as taking place in one's imagination, Arendt placed this process in an actual community. Nedelsky, "Relational Autonomy" supra note 8 at 108-09.

274 Ibid. at 110.

${ }^{275}$ Arendt, Kant Lectures at 42-43, quoted in Ibid. at 108.
} 
the existence of multiple viewpoints. This is preferable to traditional conceptions of impartiality as a "blank slate" because it acknowledges social reality and does not strive for an unattainable ideal. ${ }^{276}$

Another element that emerges from Arendt's theory of judgment is its inherently social character. ${ }^{277}$ In order to engage in the exercise of judgment as Arendt envisages it, communication and communicability are of crucial importance. The exercise of judgment takes place within an actual community; the perspectives that one takes into consideration are those of real others, thus requiring dialogue. ${ }^{278}$ The thinking process that is involved in judging, unlike reasoning, involves anticipated communication with others with whom the judge must come to an agreement. ${ }^{279}$ Persuading others of the validity of one's judgment also requires communication, which then acts to reinforce community. ${ }^{280}$

While Arendt might have believed that taking into account the perspectives of others was sufficient to achieve an enlarged mentality and therefore true impartiality, others have questioned our ability to imagine the perspectives of others. One risk is that taking the perspectives of others in an attempt to expose one's hidden assumptions might in fact reinforce those assumptions. ${ }^{281}$ Iris Marion Young notes the irreversibility of positions in

\footnotetext{
${ }^{276}$ See above at 43.

${ }^{277}$ Also attractive are the inherently egalitarian values that underlie Arendt's exercise of taking the perspectives of others into account, which implies that those views are equally worthy of consideration.

${ }^{278}$ Nedelsky, "Relational Autonomy" supra note 8 at 108.

${ }^{279}$ Minow, "Justice Engendered" supra note 67 at 93, quoting Hannah Arendt.

${ }^{280}$ Nedelsky, "Relational Autonomy" supra note 8 at 108.

${ }^{281}$ Minow, "Justice Engendered" supra note 67 at 79 . The risk of judges making assumptions based on the ethnic origin of individuals appearing before them see Sonia Lawrence, "Cultural
} 
situations such as that of an able-bodied person imagining life as a disabled

person. Able-bodied persons consistently underestimate the quality of life of the

disabled. Rather than to consider the perspective of the other, able-bodied

persons think of how they would feel if they were confined to a wheelchair. ${ }^{282}$

Members of dominant groups cannot speak for or reason as marginalized groups

would for themselves because they "cannot escape the particularity of their own

experience."283 She thus advocates group representation to overcome those

barriers:

Group representation unravels the false consensus that cultural imperialism may have produced, and reveals group bias in norms, standards, styles and perspectives that have been assumed as universal or of highest value. By giving voice to formerly silenced or devalued needs and experiences, group representation forces participants in discussion to take a reflective distance on their assumptions and think beyond their own interests. When confronted with interests, needs and opinions that derived from very different social positions and experience, persons sometimes come to understand the limitations of their own experience and perspective for coming to a conclusion about the best policy for everyone. $^{284}$

This very brief and simplified account of Arendt's theory of judgment has

its limitations. The complexity of judgments across different communities and the plurality of values and perspectives means that while judgments can take into consideration the perspectives of others, they will not necessarily satisfy them. ${ }^{285}$ With Arendt's more sound and realistic conception of impartiality, however, it is

(In)sensitivity: The Dangers of a Simplistic Approach to Culture in the Courtroom" (2001) 13 Can. J. Women \& L. 107 and Kathleen Mahoney, "The Myth of Judicial Neutrality: The Role of Judicial Education in the Fair Administration of Justice" (1996) 32 Williamette Law Review 785 at 812.

282 Iris Marion Young, "Asymmetrical Reciprocity: On Moral Respect, Wonder, and Enlarged

Thought" in Beiner \& Nedelsky, eds., supra note 8 at 209.

${ }^{283}$ Williams, supra note 19 at 140.

${ }^{284}$ Melissa Williams, "Impartial Justice and Partial Perspectives" in Patrick Hanafin \& Melissa Williams, eds., Identity, Rights, and Constitutional Transformation (Brookfield: Ashgate, Aldershot, Hants, England) at 66, quoting Iris Marion Young.

${ }^{285}$ Nedelsky, "Relational Autonomy" supra note 8 at 116-17. 
possible to begin to envisage how a more diverse judiciary would in fact foster rather than diminish impartiality.

\section{Including Multiple Perspectives to Create a "Community of Judgment"}

In order to support arguments for judicial diversity, Jennifer Nedelsky takes Arendt's theory of judgment a step further. Judges, as do all persons exercising the faculty of judgment, engage in the exercise of "wooing the consent" of others in their community of judgment. They test their judgments by imagining how the judgment will be viewed and received by their colleagues and can thereby be assured that their decisions are not arbitrary or biased. ${ }^{286}$ If the perspectives that judges take into consideration and test their own judgments against are limited or simply reflect their own, however, it is not possible to engage in optimal judgment. Moreover, exposure to other perspectives through litigants is insufficient. In order to overcome the limitations of their own perspectives, judges must be confronted with the differing views of those whom they think they must persuade, in both actual and imaginary dialogue. ${ }^{287}$ Nedelsky argues that "[b]y expanding the diversity of the bench, judges will more easily cultivate an enlarged mentality, reflecting on the perspectives of others to reveal the limitations of their own." ${ }^{288}$ The presence of judges from racialized and other previously excluded groups thus confronts judges with the reality of

\footnotetext{
${ }^{286}$ Nedelsky, "Relational Autonomy" supra note 8 at 115.

287 Ibid. at 114.

${ }^{288}$ Ibid.
} 
normative diversity. It can also help sensitize them to the particularities of alternative views. ${ }^{289}$

Another variation on Arendt's theme of taking into account the perspectives of others when judging is Lazos Vargas's "pluralistic process-based model of judging." According to this model, the inclusion of minority perspectives is necessary and has value beyond perceptions of fairness. ${ }^{290}$ Judges and adjudicators must confront assumed truths and question assumptions that society has normalized. Judges must ultimately, through their reasons, account for why they have chosen one social truth over another. ${ }^{291}$ A necessary step to a pluralistic ethic of judging is thus the inclusion of minority judges and outsider perspectives. ${ }^{292}$

Perhaps the most powerful example of the impact of a racialized judge and his unique perspectives on a community of judgment is that of Justice Thurgood Marshall, the first African American judge on the U.S.S.C. Justice Marshall's impact was not due solely to his presence as the only black judge on the highest court. He was consistently willing to share minority perspectives to challenge and persuade his colleagues to interpret legal doctrine differently, that is, in the context of marginalized groups. ${ }^{293}$ Justice Marshall thus advanced perspectives and values that were previously unrepresented and in all likelihood unfamiliar among his colleagues. Justice Sandra Day O'Connor, who shared the

\footnotetext{
${ }^{289}$ Webber, supra note 126 at 27.

${ }^{290}$ Lazos Vargas, "Grutter and Diversity" supra note 119 at 140.

$291 \mathrm{lbid}$. at 142. This echoes the "ethos of justification" that has come to be seen as an element of fairness in Canadian administrative law through, for example, the duty to give reasons. Chief Justice McLachlin, "Rule of Law" supra note 102 at 174.

${ }^{292}$ Lazos Vargas, "Grutter and Diversity" supra note 119 at 143.

293 Ifill, "Racial Diversity" supra note 66 at 484-85.
} 
bench with Justice Marshall for 10 years, described his influence on her as

follows:

Although all of us come to the Court with our own personal histories and experiences, Justice Marshall brought a special perspective. His was the eye of a lawyer who saw the deepest wounds in the social fabric and used law to help heal them. His was the ear of a counselor who understood the vulnerabilities of the accused and established safeguards for their protections. His was the mouth of a man who knew the anguish of the silenced and gave them a voice.

At oral arguments and conference meetings, in opinions and dissents, Justice Marshall imparted not only his legal acumen but also his life experiences, constantly pushing and prodding us to respond not only to the persuasiveness of legal argument but also to the power of moral truth. ${ }^{294}$

Justice O'Connor expressed her enduring hope of hearing "another story

that would, by and by, perhaps change the way I see the world."295 Justice Byron White expressed a similar view of Justice Marshall's impact: "[he] characteristically would tell us things that we knew but would rather forget; and he told us much that we did not know due to the limitations of our own experience."296 Justice Marshall, while no doubt a particularly persuasive force, demonstrates the potential for racialized judges or adjudicators to share with their colleagues perspectives that were previously absent or unheard of among nonracialized groups. These perspectives can then inform legal decision-making and force judges and adjudicators to rethink legal concepts and their application to different contexts. In this way, diversity can thus have a real, substantive impact on legal deliberations and decision-making.

\footnotetext{
${ }^{294}$ Sandra Day O'Connor, "Thurgood Marshall: The Influence of a Raconteur" (1992) 44 Stan. L. Rev. 1217.

${ }^{295}$ Ibid. at 1220. Justice O'Connor, who graduated Stanford Law School at the top of her class only to be offered positions as a legal secretary, likely had experiences that affected her perspectives as well. Ibid. at 1219.

296 Justice Byron R. White, "A Tribute to Thurgood Marshall" (1992) 44 Stan. L. Rev. 1215 at 1216, quoted in Kevin R. Johnson \& Luis Fuentes-Rohwer, "A Principled Approach to the Quest for Racial Diversity on the Judiciary" (2004) 10 Mich. J. Race \& L. 5 at 13.
} 
Some would cite Justice Marshall's successor, Justice Clarence Thomas, as a counter-example to the value of racial diversity on the bench. Justice Thomas, while African American, has adopted positions hostile to race-conscious measures such as affirmative action. ${ }^{297}$ Moreover, his conservatism is seen as limiting his ability to advance the perspectives or interests of racialized groups. Justice Thomas's influence leads to the question of whether racial diversity is the goal or whether it is to have judges and adjudicators who are more sympathetic to racialized groups. Justice Thomas has, however, on occasion invoked a racebased analysis that shows nuance and sensitivity to a racialized perspective. ${ }^{298}$ Even his opposition to affirmative action is arguably race-based, as he believes that it stigmatizes racial minorities, ultimately doing more harm than good. ${ }^{299}$

The example of Justice Thomas does not, however, weaken the rationale for racial diversity on the judiciary and in administrative tribunals. Rather, it demonstrates that there is no single "Black" or racialized perspective and that as a result, representation beyond tokenism is required. The risk of having racialized perspectives represented by a Clarence Thomas is that his would be the only perspective available to counter the weight of dominant group perspectives. The presence of more racialized judges or adjudicators would, however, ensure the availability of a broader range of perspectives to perform that function. ${ }^{300}$

${ }^{297}$ Lazos Vargas, "Grutter and Diversity" supra note 119 at 136.

298 lbid. at 147 and Johnson \& Fuentes-Rohwer, supra note 296 at 14-15. But see Ifill, "Racial Diversity" supra note 66 at 487 for a contrary view of how Justice Thomas has used racial narratives to further conservative positions.

${ }^{299}$ Lazos Vargas, " Grutter and Diversity" supra note 119 at 136.

${ }^{300}$ Ibid. at 148. 
The "community of judgment" effect might be most visible on appellate courts or on tribunal panels of more than one adjudicator, because the judges or adjudicators will discuss the case and deliberate collectively. Indeed, the purpose of sitting in panels is likely based upon the conviction that multiple viewpoints help arrive at better decisions. ${ }^{301}$ The process of cultivating an enlarged mentality upon which the community of judgment concept is based also occurs when a single judge or adjudicator exercises the faculty of judgment. They will challenge their perspective and assumptions with those of the judges and adjudicators who form part of the community that they are trying to persuade. While judges do not discuss with their judicial colleagues the specifics of cases they are hearing, they do interact with one another and discuss cases and the law in general, ${ }^{302}$ thus providing the opportunity for exchanging perspectives. Because they are not subject to as stringent limitations, administrative adjudicators meet regularly, circulate draft decisions and have even greater opportunity for exposure to the viewpoints of their colleagues. The opportunities for such interchange are further explored in Chapter IV.

\section{Diversity Leads to Structural Impartiality}

Echoes of Arendt's theory of judgment can be heard in Sherrilyn Ifill's argument that judicial diversity is necessary in order to overcome institutional biases and to achieve "structural impartiality:"

Structural impartiality exists when the judiciary as a whole is comprised of judges from diverse backgrounds and viewpoints. The interaction of these diverse

${ }^{301}$ Devlin et al., supra note 75 at 795 .

302 Ibid. 
viewpoints fosters impartiality by diminishing the possibility that one perspective dominates adjudication. ${ }^{303}$

In a manner similar to Nedelsky's "community of judgment" concept and Arendt's conception of impartiality, structural impartiality is achieved by the interaction of a diverse group of judges. The exclusion of identifiable groups that may have different perspectives or views can potentially undermine impartiality. ${ }^{304}$ This interaction increases the likelihood that all judges will "adjudicate with racial dimensions with greater sensitivity, information and exposure to the diverse values and perspectives that exist within the community." ${ }^{305}$ As a result, racial diversity enhances rather than diminishes impartiality and has an impact beyond the cases decided by racialized judges.

It is possible that the "dampening effect" of female judges that the Stribopoulos Study identifies is evidence of structural impartiality in action. Because we cannot inquire into the judges' deliberations and the discussions that led individual judges to vote differently than they otherwise might have, it is impossible to know exactly what factors were at work. It does appear, however, that gender and political diversity tempered the way in which some judges voted. At the very least, it points to the malleability of legal and ideological beliefs and conclusions in the face of differing views from one's colleagues. As a result of the "dampening effect" of gender on appellate decisions, the Stribopoulos Study concludes that "diversity in the political and gender mix of appellate court panels is essential." ${ }^{306}$

\footnotetext{
${ }^{303}$ Ifill, "Judging the Judges" supra note 9 at 99.

$304 \mathrm{Ibid}$. at 127.

305 Ibid. at 128.

${ }^{306}$ Stribopoulos \& Yahya, supra note 259 at 362.
} 
The concepts of community of judgment and structural impartiality both go beyond the individual rationale, which focuses mainly on the impact of individual racialized judges on the cases that they decide. Viewed more broadly, the value of diversity is that it can enrich legal decision-making by including a variety of voices and perspectives in the deliberative process. ${ }^{307}$ This vision of diversity "involves reasoning about the way in which the institutional output of the judiciary as a whole might change if we increased the overall number of minority judges and sought to include substantial numbers from all racial and ethnic groups." ${ }^{308}$ Judges themselves have recognized the importance of the presence of diverse perspectives on the judiciary as a means of ensuring better decisionmaking. ${ }^{309}$ Judge Harry T. Edwards puts it as follows:

I do not know how to quantify these racial differences; but I am convinced that they exist and should be given voice to in our judicial deliberations.... And in a judicial environment in which collegial deliberations are fostered, diversity among the judges makes for better-informed discussion. ... A deliberative process enhanced by collegiality and a broad range of perspectives necessarily results in better and more nuanced opinions - opinions which, while remaining true to the rule of law, over time allow for a fuller and richer evolution of the law. ${ }^{310}$

\section{a. The Jury as an Example of Structural Impartiality}

The wisdom of the community of judgment approach that Nedelsky envisages and the structural impartiality that Ifill advocates are already employed in a particular context: the jury. In the U.S., diversity is seen as a valid consideration in selecting an impartial jury. Diversity is seen to promote impartiality by ensuring that no particular perspective or set of values can

\footnotetext{
307 Ifill, "Racial Diversity" supra note 66 at 405.

308 Milligan, "Pluralism in America" supra note 212 at 1236.

309 Ibid.

${ }^{310}$ Edwards, supra note 79 at 329.
} 
dominate in jury deliberations. ${ }^{311}$ Thus, the U.S. Supreme Court has recognized that the Fourteenth and Sixth Amendments compel not only individual impartiality but also structural impartiality on the jury venire. Jury venires must therefore reflect a fair cross-section of the community. ${ }^{312}$ In one case, the Court struck the conviction of a white defendant in a case in which African Americans had been excluded from the jury pool. Justice Marshall, writing for the majority stated:

When any large and identifiable segment of the community is excluded from jury service, the effect is to remove from the jury room qualities of human nature and varieties of human experience, the range of which is unknown and perhaps unknowable. ${ }^{313}$

In Canada as well, the jury must be drawn from "a representative crosssection of society, honestly and fairly chosen."314

The jury, through its collective decision making, is an excellent fact-finder; due to its representative character, it acts as the conscience of the community; the jury can act as the final bulwark against oppressive laws or their enforcement; it provides a means whereby the public increases its knowledge of the criminal justice system and it increases, through the involvement of the public, societal trust in the system as a whole. ${ }^{315}$

The essential quality that the representativeness requirement ensures is the possibility of different perspectives from a diverse group of persons. The representativeness requirement seeks to avoid the risk that persons with different perspectives, and who are otherwise available, will be systematically excluded from the jury roll. ${ }^{316}$ In the recent case of R. v. Buckingham, a jury list drawn from a motor vehicle licensing list which had not been updated since 1999 was found to be unrepresentative because it excluded those who had not reached

\footnotetext{
${ }^{311}$ Ifill, "Judging the Judges" supra note 9 at 120.

${ }^{312}$ Witherspoon v. Illinois, 391 U.S. 510, 524, 528 (1968) cited in Ibid. at 120.

${ }^{313}$ Peters v. Kiff, 407 U.S. 493 at 592 (1972), cited in Ifill, "Judging the Judges" supra note 9 at 121. The U.S.S.C. has held that the exclusion of women, African Americans and Mexican Americans from the jury pool is damaging to the impartiality of the jury venire. Ibid.

${ }^{314}$ R. v. Sherratt, [1991] 1 S.C.R. 509, 1991 CarswellMan 7 at para. 31.

$315 \mathrm{lbid}$. at para. 30.

${ }^{316}$ R. v. Teerhuis-Moar, 2007 MBQB 165 at para. 57.
} 
driving age by the time the list was compiled, those who moved in to the area since then and individuals who, because of disability or otherwise, did not have a driver's licence or own a motor vehicle. ${ }^{317}$ The representativeness requirement, however, does not guarantee the accused to a particular jury composition. ${ }^{318}$

Thus, the benefit of diverse perspectives to legal decision-making, as represented by the fair cross-section requirement for juries, has long been accepted. As a result, it would seem to follow that a more diverse body of judges and adjudicators will also help to overcome institutional biases to achieve an enhanced level of impartiality, or structural impartiality.

\section{b. The Necessity of a Critical Mass}

The inherent value of exposure to diverse perspectives has also been recognized in the educational context in Regents of the University of California $v$. Bakke ${ }^{319}$ and Grutter v. Bollinger. ${ }^{320}$ In Bakke, the U.S.S.C. upheld the constitutionality of the university's race-conscious admission measures in law and medicine on the basis that diversity would bring "experiences, outlooks, and ideas that enrich the training of its student body and better equip its graduates to render with understanding their vital service to humanity." 321 Similarly, in Grutter, supra, the U.S.S.C. upheld the University of Michigan Law School's affirmative action program. The law school had a race-conscious admissions policy ${ }^{322}$ that aimed at admitting a "critical mass" of racialized students. The Court confirmed

\footnotetext{
${ }^{317}$ R. v. Buckingham, 2007 NLTD 107.

${ }^{318}$ R. v. Gayle (2001), 54 O.R. (3d) 36, [2001] O.J. No. 1559 (QL)

${ }^{319}$ Regents of the University of California v. Bakke, 438 U.S. 265 (1978).

${ }^{320}$ Grutter v. Bollinger, 539 U.S. 306 (2003).

${ }^{321}$ Bakke, supra note 319 at 314, cited in Ifill, "Judging the Judges" supra note 9 at 125.

322 For a full description of the policy, see Lazos Vargas, "Grutter and Diversity" supra note 119 at 114.
} 
that the goal of a racially diverse student body that went beyond token representation in order to stimulate a robust exchange of perspectives in class discussions and informal settings was a legitimate state purpose. ${ }^{323}$

A critical mass is a sufficient number of racialized students, such that those students are able to express their views freely. The rationale for a "critical mass" is that the objectives of diversity cannot be achieved by token representation because the few racialized students present would likely feel more pressure to assimilate and would not be comfortable expressing views and experiences different from the majority. The concept of a "critical mass" would also appear to be relevant to courts and tribunals. ${ }^{324}$ Although it might seem implausible that a judge or adjudicator could be susceptible to a need to conform to the culture or expectations of the working environment, such pressure has been acknowledged. One female judge has noted:

For now, the judiciary is still a newly integrated male club, and women judges are expected to be agreeable, charming, bright, incisive, non-threatening, loyal, not irritatingly individualistic, supportive, cheerful, attractive, maybe witty - to a point, but not pushy, insistent, aggressive, sarcastic, unyielding, or any of the other qualities our male colleagues exhibit every day. ${ }^{325}$

The absence of colleagues from similar backgrounds can result in racialized judges and adjudicators feeling uncomfortable or constrained in articulating values and perspectives that reflect those of racialized groups or that conflict with dominant perspectives:

A token number of minorities may not be able to muster a sustained exchange. Individual minority judges might shy away from making their colleagues uncomfortable and choose to 'get along' rather than educate them on racial

${ }^{323}$ Grutter, supra note 320 at 334.

324 Lazos Vargas, "Grutter and Diversity" supra note 119 at $143 \mathrm{ff}$.

325 Dame Hale, "More Women Judges" supra note 13 at 498 quoting Patricia Wald, Circuit Judge, U.S. Court of Appeals for the District of Columbia, "Some Real-Life Observations about Judging" (1992) 26 Indiana L. Rev. 173. 
issues, or an individual minority judge's racial perspectives may not be sufficiently dissimilar from the majorities' racial perspectives to spur dialogic exchange. The key is that there be sufficient numbers of minorities so that a wide range of views on race can be freely expressed and colleagues will be pushed to rethink assumptions that might be based on stereotypes or privilege. ${ }^{326}$

In order to achieve a diverse, discursive body, diversity must mean the inclusion of a critical mass of racialized persons. ${ }^{327}$ As noted previously, the diversity of views and beliefs among racialized groups also militates for more than token representation.

\section{B. An Integrative Conception of Diversity: Diversity Enriches Legal Decision-Making}

To summarize briefly, I began this paper by examining the institutional rationale for diversity. I argued that although valid, purely formal arguments for greater diversity on courts and tribunals are insufficient. I then unpacked the individual rationale that diverse judges and adjudicators bring different perspectives to the task of adjudication. This argument is essential to calls for greater diversity because it specifically highlights the substantive impact of racialized judges and adjudicators.

In this Chapter, I have relied upon the concepts of community of judgment and structural impartiality to go one step further. These concepts point to a more integrative approach to diversity that draws from the individual and institutional rationales but extends beyond both to reveal the true value of diversity and its transformative potential. The impact of racialized judges and adjudicators, and their unique experiences and perspectives, is more than the decisions that they render. By bringing diverse and traditionally excluded perspectives to the

\footnotetext{
${ }^{326}$ Ifill, "Racial Diversity" supra note 66 at 413 . See also Lazos Vargas, "Grutter and Diversity" supra note 119 at $145-46$.

${ }^{327}$ Lazos Vargas, "Grutter and Diversity" supra note 119 at 109.
} 
institutions to which they belong, they help to expose hidden institutional biases and expand the range of knowledge and experience that the institution as a whole possesses. This will thus impact upon the entire institution's decisionmaking:

When different perspectives are represented among their colleagues judges are less likely to fall into an easy consensus, a consensus which may not reach much beyond the courthouse, large downtown firms, and those firms' clients. ${ }^{328}$

Deliberations among a panel of adjudicators or appellate judges is one example of how this can occur, but day-to-day interactions, meetings and conferences provide further opportunities for the exchange of viewpoints. The success of this integrative conception of diversity thus depends not only upon the presence of diverse judges and adjudicators, but also the opportunity for interaction and an openness to dialogue. The administrative context is particularly well-suited to this approach to diversity.

\section{Administrative Tribunals: An Ideal Setting for an Integrative Conception of Diversity}

As argued earlier in this thesis, the discretion that administrative adjudicators possess and the complexity of administrative decision-making in a pluralistic society support greater diversity on tribunals. Because discretion is "sponge-like" 329 and absorbs the values, assumptions and preferences to which it is exposed, it is important that adjudicators be exposed to a wide range of values, assumptions and preferences. One way to ensure that decision-makers are "alert, alive and sensitive" is through a more diverse corps of administrative adjudicators with a broader range of experiences, values and preferences.

${ }^{328}$ Webber, supra note 126 at 27.

${ }^{329}$ Houle, "L'arret Baker" supra note 149. 
Applying an integrative approach to diversity, the value of such diversity is not limited to the influence of racialized adjudicators on the cases that they hear, but on the awareness of the tribunal, and therefore its decision-making capacity as a whole. Diversity will also enhance participation and justification, two principles of key importance to the administrative justice system.

\section{a. Participation}

One of the reasons the Baker decision is so influential is because it firmly entrenched participation as central to procedural fairness:

The values underlying the duty of procedural fairness relate to the principle that the individual or individuals affected should have the opportunity to present their case fully and fairly and have decisions affecting their rights, interests and privileges made using a fair, impartial and open process, appropriate to the statutory, institutional and social context of the decision. ${ }^{330}$

Discretionary decision-making thus requires the full participation of the individual who will be affected by the decision. In her analysis of Baker, Geneviève Cartier suggests that Baker requires that discretion be conceived from the perspective of the individual affected by the decision. ${ }^{331}$ Cartier proposes a new conception of discretion as a dialogue between the decision-maker and the individual. ${ }^{332}$ This requires both the individual and the decision-maker to put themselves in the position of the other participant, in order to understand their perspective and contribute to a decision that is responsive to the individual's situation and

\footnotetext{
${ }^{330}$ Baker, supra note 6 at para. 28.

${ }^{331}$ Geneviève Cartier, "The Baker Effect: A New Interface Between the Canadian Charter of Rights and Freedoms and Administrative Law - the Case of Discretion" in David Dyzenhaus, ed., The Unity of Public Law (Oxford,: Hart Publishing, 2004) 61 at 83.

${ }^{332}$ Geneviève Cartier, "Reconceiving Discretion: From Discretion as Power to Discretion as Dialogue" (SJD Thesis, University of Toronto, 2004) [unpublished] at 270ff. See also Minow, "Justice Engendered", supra note $\mathrm{x}$ at 69-70: "Taking minority perspectives seriously calls for a process of dialogue in which the listener actually tries to reach beyond the assumption of one reality, one version of the truth."
} 
consistent with legislative intent and public interest. ${ }^{333}$ Participation is thus conceived of as not merely procedural, but as having substantive content. Beyond establishing the particulars of their situation, the individual is able to have input into the norms that will affect the decision. ${ }^{334}$

Using Cartier's conception of discretion as dialogue, it is possible to envisage how diversity will foster the principle of participation that Baker has identified as central to fairness. Given the difficulties involved in taking the perspective of another person, the ability to do so is always limited, especially when the other person is of a different background. The presence of more racialized and other diverse adjudicators on a tribunal, however, would help expose assumptions and present alternative viewpoints and would enhance the capacity of all members to consider the perspectives of others. This increases the likelihood that the individual's perspective will both be heard and understood, allowing for fuller participation. "Including individuals from these groups in the deliberative decision-making processes of society's institutions will allow full participation for those who have been historically excluded from deciding by what standards they will be judged and defining what perspectives and outlooks they will have."335

The potential for adjudicators to adopt and understand alternative perspectives is enhanced by the presence and contributions of racialized adjudicators. Moreover, as the values and experiences embodied by the

\footnotetext{
333 Ibid.

${ }^{334}$ Cartier, "The Baker Effect" supra note 336 at 83.

335 Sheila Foster, "Difference and Equality: A Critical Assessment of the Concept of "Diversity"' (1993) Wisc. L. Rev. 105 at 154.
} 
tribunal's membership expands, the individuals who appear before them are more likely to have their values reflected in the tribunal. The overcoming of hidden institutional biases and adherence to the status quo, along with the increased awareness and enhanced capacity to understand alternative perspectives all mean that the individual can more fully participate in the administrative decision-making process. Chapter IV of this thesis will show that the value of participation is not simply theoretical.

\section{b. Justification}

Without knowing the basis for a decision or without feeling that she has been heard by all persons participating in the decision-making process, how can a citizen honestly be told that the resolution of her problem is binding and legitimate? ${ }^{336}$

Diversity will also cultivate another Baker principle - the "ethos of justification." 337 Justification takes on greater importance in a diverse society where different and competing values are at play. ${ }^{338}$ Unacknowledged majoritarian assumptions should not form the basis of decisions. In Lazos Vargas' "pluralistic process-based model of judging"339 she argues that through their reasons, judges must account for why they have chosen one social truth over another. ${ }^{340}$ This would avoid the pitfall of making judgments based on unconscious assumptions and would also foster the legitimacy of the result.

\footnotetext{
${ }^{336}$ Chief Justice McLachlin, "The Rule of Law" supra note 102 at 188.

${ }^{337}$ Mary Liston, "'Alert, alive and sensitive': Baker, the Duty to Give Reasons, and the Ethos of Justification in Canadian Public Law" in David Dyzenhaus, ed. The Unity of Public Law (Portland: Hart Publishing, 2004) 113, at 114.

${ }_{338}^{338}$ McLachlin, "The Rule of Law" supra note 102 at 189.

${ }^{339}$ See page 77 above.

${ }^{340}$ Lazos Vargas, at 142. See also Minow, "Justice Engendered" supra note 67 at 94: "Judicial power is least accountable when judges leave unstated - and treat as a given - the perspective they select... the status quo cannot be immune from demands for justification."
} 
Similarly, the discretionary decisions of administrative adjudicators should be accompanied by reasons that reflect a full consideration of the different values and perspectives at issue. Participation, through the presence of diverse adjudicators and the individual's participation, ensures that alternative perspectives are included in the decision-making process. The requirement of justification guarantees that the decision is based upon a careful consideration of those perspectives and not simply the inevitable result of unstated values and preferences. The adjudicator's reasons would then encourage further dialogue ${ }^{341}$ and transparency, thereby enhancing fairness and perceptions of fairness.

Somewhat presciently, Arendt argued that a judgment's "claims to validity can never extend further than the others in whose place the judging person has put himself for his considerations." ${ }^{342}$ The failure to take into consideration the perspectives of certain groups in society undermines the legitimacy of an institution's decisions. We thus return to the starting point - institutional legitimacy as a rationale for diversity. According to an integrative conception of diversity, however, it is not the presence of adjudicators from racialized groups alone that will lend greater legitimacy to a tribunal's decisions. The potential substantive impact of racialized adjudicators must be acknowledged and embraced. Moreover, the impact of racialized adjudicators is not limited to the decisions they render but extends to the institution itself. Diversity will challenge long-held assumptions, help overcome hidden institutional biases, expand the

\footnotetext{
${ }^{341}$ Sossin, "Culture of Justice" supra note 2 at 382-83.

${ }^{342}$ Nedelsky, "Relational Autonomy" supra note 8 at 116.
} 
institution's knowledge and lead to structural impartiality, all of which enhances its capacity to render decisions that are both fair and perceived to be fair in a diverse society. This would be the ultimate guarantee of legitimacy and public confidence. An integrative conception of diversity thus points to the true value of diversity and all its transformative potential. 


\section{CHAPTER IV - A GLIMPSE: QUALITATIVE RESEARCH INTO THE POTENTIAL IMPACT OF DIVERSITY}

\section{A. Introduction}

As argued in the previous sections of this thesis, the argument for increased representation of racialized groups on administrative tribunals is largely based upon two distinct rationales. The first is that the presence of adjudicators from racialized groups will increase the legitimacy of those tribunals. The second is that adjudicators from diverse groups, such as racialized groups, will bring different perspectives to the task of adjudication as a result of their unique experiences. In this thesis, I have argued that the institutional or formal rationale for diversity is insufficient and that arguments for diversity must also rely upon the individual or substantive rationale. Diversity of adjudicators enhances the structural impartiality of administrative tribunals, thus resulting in decisionmaking that better reflects the values and experiences of a diverse society. If decisions are seen as more adequately reflecting the various social realities of marginalized groups, such as racialized persons, the institutions will inspire greater public confidence and thus be perceived as more legitimate.

The arguments for a diverse or more representative judiciary are familiar

ones. The extension of these arguments to the administrative context does not require a huge leap in logic. The previous sections have demonstrated how arguments for diversity might in fact be more compelling in the administrative context. The arguments for diversity, however, face a number of barriers, including traditional conceptions of impartiality and the role of judges and adjudicators. Many attempts have been made to justify judicial diversity with 
empirical evidence of a substantive impact, particularly in the U.S. However, many of those studies have focused solely on outcomes, leading to inconclusive or contentious results. As I have argued, the value of diversity goes beyond outcomes and is very much about the process through which decisions are made.

In order to test whether or not diversity has any substantive impact in the administrative context, I conducted a limited number of interviews with certain tribunals and lawyers who appear before them. The purpose of my research was limited to examining whether the rationales articulated to support diversity could be seen in the experience and practice of the administrative tribunals in question. It was not possible in a thesis of this limited scope to amass the amount of empirical research that would be required to make conclusive statements. Moreover, factors such as the absence of statistics with respect to current levels of representation of racialized groups render it difficult to obtain an accurate picture. As such, I propose only to offer a glimpse into the potential impact of racial diversity on administrative tribunals. I will begin this part by outlining the methodology used to conduct the research.

\section{B. Methodology}

\section{Access to Information and Freedom of Information Requests}

As a starting point, my objective was to determine, to the extent possible, current levels of representation of racialized groups on certain administrative tribunals (see below). I sought this information by making access to information $(\mathrm{ATI})$ and freedom of information (FOI) requests to the appropriate government 
bodies $^{343}$ and by requesting the information from two organizations of administrative adjudicators. ${ }^{344} \mathrm{I}$ also attempted to address this question by interviewing an organizational representative (generally, the Chair) of the administrative tribunals that agreed to participate in the study.

\section{Interviews with Adjudicators and Legal Clinics}

The next question that I sought to address was whether or not the presence of racialized adjudicators on certain tribunals had any impact on the tribunal itself. I chose tribunals that deal with important areas of social policy and that are likely to deal with a diverse clientele on issues that would be of critical importance to the individuals who appear before them. As such, I contacted the Landlord Tenant Board of Ontario (LTB), the Social Benefits Tribunal (SBT), the Workplace Safety and Insurance Appeals Tribunal (WSIAT), the Human Rights Tribunal of Ontario (HRTO), the Ontario Labour Relations Board (OLRB) and the Immigration and Refugee Board (IRB). ${ }^{345}$ The LTB, SBT, WSIAT and IRB declined to participate. ${ }^{346}$

Of the tribunals that agreed to participate in the research, all full-time adjudicators were invited to participate in interviews. Participation was on a voluntary basis, and was not limited to either racialized or non-racialized adjudicators. The format of the interviews was semi-structured. A list of

\footnotetext{
${ }^{343}$ Access to Information Request to the Immigration and Refugee Board, dated February 4, 2009 (on file with author); Access to Information Request to the Canadian Human Rights Tribunal, dated February 4, 2009 (on file with author); Access to Information Request to the Privy Council Office dated March 9, 2009 (on file with author); Freedom of Information Request to the Cabinet Office of the Province of Ontario, dated March 5, 2009 (on file with author)

${ }^{344}$ Letter to CCAT dated February 10, 2009 (on file with author); Letter to SOAR dated February 10, 2009 (on file with author).

${ }^{345}$ For the purposes of conducting in-person interviews, the tribunals were limited to those located in the Toronto area.

${ }^{346}$ Letters on file with author.
} 
questions was provided to the participants in advance but the interviews were not limited to those questions. Six full-time Vice-Chairs of the HRTO, in addition to the Chair, participated in interviews. Of the seven HRTO participants, four selfidentified as racialized persons. ${ }^{347}$ The Chair and one full-time Vice-Chair of the OLRB participated in interviews. Neither of the two OLRB participants selfidentified as racialized. ${ }^{348}$ Although the OLRB consented to participate in the study, there are currently no members of racialized groups among the 25 fulltime Vice-Chairs on the OLRB. ${ }^{349}$ As a result, it is not possible to test the impact of racialized adjudicators on that particular tribunal. ${ }^{350}$

A further objective of this study was to determine if there is any perceived impact of racialized adjudicators on the part of those who appear before them. I contacted 12 legal clinics in the Toronto area, including a number of clinics that serve particular ethnic or racialized groups. ${ }^{351}$ Of the legal clinics that I contacted, the following agreed to participate in the study: the Kensington Bellwoods Community Legal Services (KBCLS), the Metro Toronto Chinese and Southeast Asian Legal Clinic (MTCSALC), and the South Asian Legal Clinic of Ontario (SALCO). At each of the clinics that participated, I interviewed one or

\footnotetext{
${ }^{347}$ Notes of interview with D, a Vice-Chair of the HRTO, dated May 7, 2009 ("D Interview", on file with author), Notes of interview with F, a Vice-Chair of the HRTO, dated May 7, 2009 ("F Interview", on file with author), E Interview, G Interview.

${ }^{348}$ Notes of interview with Kevin Whitaker, Chair of the OLRB, dated April 5, 2009 ("Whitaker Interview"; on file with the author).

${ }^{349}$ Again, as neither the provincial government, nor the OLRB maintain statistics with respect to the racial origin of its adjudicators, this is based upon the personal knowledge of the Chair.

${ }^{350}$ Notes of interview with $\mathrm{H}$, a full-time Vice-Chair of the OLRB, dated April 27, 2009 (" $\mathrm{H}$ Interview", on file with the author).

${ }^{351}$ The clinics that were contacted were: the African Canadian Legal Clinic, the Metro Toronto Chinese and Southeast Asian Legal Clinic, the South Asian Legal Clinic of Ontario, the Centre for Spanish-speaking Peoples, Refugee Law Office - Toronto, the Rexdale Community Legal Clinic, the South Etobicoke Community Legal Services, the Scarborough Community Legal Services, the Kensington Bellwoods Community Legal Services, Parkdale Community Legal Services, Jane Finch Community Legal Services, and Neighbourhood Legal Services.
} 
two staff lawyers. The format of these interviews was also semi-structured, with a list of questions being provided in advance. With both the tribunals and the legal clinics, I chose to conduct interviews as opposed to sending out surveys because interviews would provide a better opportunity for lengthier and more detailed responses to the areas of inquiry.

I acknowledge that a more accurate view of the perception of racialized adjudicators held by litigants would be obtained by interviewing the litigants themselves. However, again because of the limited time and scope of this study, I chose to interview legal clinic lawyers because they appear before a variety of tribunals in a number of cases, while litigants would only have experienced their own case and would thus have no basis for comparison. It would also be necessary to interview many more litigants in order to obtain a large enough sampling to make any observations.

Clearly, it is not possible to make conclusive findings on the basis of a study of this limited scale and scope. The purpose, rather, was to test the theoretical arguments for increased racial diversity and to determine whether they have some basis in practice. The answers reported in this thesis could then justify further empirical inquiry into the subject matter. This might include field research in the form of observing hearings conducted by both racialized and nonracialized adjudicators with both racialized and non-racialized litigants.

Indeed, this inquiry was largely inspired by an extensive U.K. study, "Tribunals for diverse users," 352 that examined access, expectations, experiences

\footnotetext{
${ }^{352}$ Genn et al., supra note 115. The Genn Study focussed on three particular tribunals, the Appeals Service (a general appeals tribunal dealing with various social benefits), the Criminal
} 
and outcomes of tribunal hearings from the perspective of tribunal users. The objective of that study was to determine whether or not "Black" or "Minority Ethnic"353 users experienced any direct or indirect disadvantage in accessing and using tribunal services. ${ }^{354}$ The Genn Study included focus group discussions with members of the general public; interviews with tribunal users before and after hearings, as well as after decisions were received; observation of hearings; interviews with adjudicators; and a review of tribunal decisions. Significantly, the study compared observations of hearings with interview responses from users. I will draw upon some of the findings of the Genn Study because, while they apply only to the specific U.K. tribunals that were the subject of the study, they shed light on the different experiences and perceptions of racialized persons before tribunals.

\section{Current Representation of Racialized Persons on Administrative $\underline{\text { Tribunals }}$}

In order to obtain statistical information regarding current levels of representation of racialized persons on administrative tribunals, I contacted two organizations of adjudicators, the Canadian Council of Administrative Tribunals $(\mathrm{CCAT})^{355}$ and the Society of Ontario Adjudicators and Regulators (SOAR) ${ }^{356}$ to

\footnotetext{
Injuries Compensation Appeals Panel, and Special Educational Needs and Disability Tribunal. Genn et al., supra note 115 at 1.

353 "Black" is defined as African or Caribbean in origin. Interestingly, one of the objectives of the study was to compare the situation of Black, South Asian and White tribunal users, recognizing that different racialized groups might be subject to different disadvantages. The study also noted "clear indications of disparities between Black African, Black Caribbean, Pakistani and Indian participants in their experiences and perceptions." Ibid. at 13, 15.

354 The Genn Study noted a dearth of research into the experiences of Black and Minority Ethnic users of tribunals. Ibid. at 9 . The same observation could be made with respect to Canadian tribunals.

${ }^{355}$ CCAT is "a national organization that supports the work of administrative tribunals and promotes excellence in administrative justice." According to CCAT's website, its goals are to: enhance and expand contact among members of the administrative justice community; promote
} 
inquire as to whether or not they maintained any information on the diversity of their membership. Neither organization participated in the study. Nor does either organization appear to have any information with respect to the racial diversity of their membership on their respective websites.

\section{The Representativeness of Federal Tribunals}

As noted above, I submitted ATI requests to the federal government regarding the representation of racialized persons on certain administrative tribunals. The federal government requests that members of tribunals selfidentify as to whether or not they belong to one or more designated employment equity groups. ${ }^{357}$ The following table summarizes the information that I received with respect to the diversity of three tribunals, the Canadian Human Rights Tribunal (CHRT), the Immigration and Refugee Board (IRB) and the Employment Insurance Board of Referees (EIBR). As a point of comparison, I have also included the number of women members on those tribunals. The table below illustrates a wide variance in the proportion of self-identified visible minorities depending upon the tribunal. There are no visible minorities among the 10 members of the CHRT, but 15.22 percent of IRB members are visible

\footnotetext{
awareness of the role and importance of administrative justice in everyday life; speak out on issues of importance to the administrative justice community; and provide support and services of value to its membership. Online: Canadian Council of Administrative Tribunals < http://www.ccat-ctac.org/en/about/>.

${ }^{356}$ SOAR is "an organization of Chairs, Members and executive staff of administrative justice system agencies." SOAR's mission is to advance administrative justice through education, advocacy and innovation. Online: Society of Ontario Adjudicators and Regulators $<$ http://www.soar.on.ca/about_soar/mission/>.

${ }^{357}$ The Employment Equity Act defines designated groups as women, aboriginal peoples, persons with disabilities and members of visible minorities. "Members of visible minorities" are defined under the Act as "persons, other than aboriginal peoples, who are non-Caucasian in race or non-white in colour[.]" Employment Equity Act, S.C. 1995, c. 44, s. 3. For all of these statistics, it is important to keep in mind that the numbers depend upon voluntary selfidentification. As a result, the number might not reflect the exact proportion of designated group members.
} 
minorities. ${ }^{358}$ The EIBR falls in the middle with 4.89 percent of its members selfidentifying as visible minorities. Based on the 2006 Census, national workforce availability of visible minorities is 15.3 percent. ${ }^{359}$ Of the three tribunals, only the IRB is close to having a representation of visible minority adjudicators that is close to workforce availability.

Table A: The Composition of Certain Federal Administrative Tribunals ${ }^{360}$

\begin{tabular}{|l|c|c|c|c|c|}
\hline \multicolumn{1}{|c|}{ Organization } & $\begin{array}{c}\text { Total People } \\
\text { for } \\
\text { Organization }\end{array}$ & \multicolumn{2}{c|}{ Women } & \multicolumn{2}{c|}{ Visible Minorities } \\
\hline & Number & Number & $\%$ & Number & $\%$ \\
\hline $\begin{array}{l}\text { Canadian Human Rights } \\
\text { Tribunal }\end{array}$ & 10 & 2 & 20 & 0 & 0 \\
\hline $\begin{array}{l}\text { Employment Insurance Boards } \\
\text { of Referees }\end{array}$ & 266 & 93 & 34.96 & 13 & 4.89 \\
\hline Immigration and Refugee Board & 138 & 66 & 47.83 & 21 & 15.22 \\
\hline
\end{tabular}

\section{The Representativeness of Federal Appointments}

In response to my ATI requests, the Privy Council Office provided the three most recent reports prepared for the Prime Minister on the representativeness of Governor in Council (GIC) appointments. ${ }^{361}$ The Reports, which appear to be biannual but are not regular, are prepared by the Privy

${ }^{358}$ The information received with respect to the IRB is not broken down to reflect the different divisions, the Immigration Appeals Division, Refugee Protection Division or Immigration Division. I did, however, receive a separate response relating to the Immigration Division, which was that as of December 31, 2008, six percent of its members self-identified as visible minorities while 49 percent self-identified as women.

${ }^{359} 2006$ Employment Equity Data Report, Executive Summary, online: Human Resources and Skills Development Canada, <http://www.hrsdc.gc.ca/eng/labour/publications/equality/eedr/2006/page02.shtml.> ${ }^{360}$ As of March 29, 2009, based on information received in response to an ATI request.

361 "Report on Representativeness of Governor in Council Appointments July 1 to December 31, 2007", "Report on Representativeness of Governor in Council Appointments January 1 to June 30, 2008", "Report on Representativeness of Governor in Council Appointments July 1 to September 30, 2008" (collectively, the "GIC Reports.") 
Council Office and contain information as to the number and percentage of GIC appointees who belong to "designated groups" under the Employment Equity Act. ${ }^{362}$ The reports also include information with respect to the number of appointees who are Francophone, Anglophone or bilingual, as well as the number of appointees from each province. The Reports state that the Privy Council Office surveys all appointees to determine the representation of aboriginal peoples, persons with disabilities and visible minorities. ${ }^{363}$ The numbers contained in the Reports for the last two years are summarized in the table below. Again, the proportion of appointees who belong to each of the groups depends upon voluntary self-identification. The number of respondents is also provided.

Table B: The Composition of Governor in Council Appointees

\begin{tabular}{|l|c|c|c|c|c|c|}
\hline \multicolumn{1}{|c|}{ Period } & \multicolumn{1}{|c|}{$\begin{array}{c}\text { Number of } \\
\text { Appointments }\end{array}$} & $\begin{array}{c}\text { Number who } \\
\text { Responded }\end{array}$ & \multicolumn{2}{|c|}{$\begin{array}{c}\text { Visible } \\
\text { Minorities }\end{array}$} & \multicolumn{2}{c|}{ Women } \\
\cline { 3 - 6 } & & & No. & $\%$ & No. & $\%$ \\
\hline $\begin{array}{l}\text { July 1 to } \\
\text { December 31, } \\
2007\end{array}$ & 328 & 293 & 26 & 5.5 & 105 & 32 \\
\hline $\begin{array}{l}\text { January 1, 2008 } \\
\text { to June 30, 2008 }\end{array}$ & 564 & 473 & 28 & 5.9 & 177 & 31.4 \\
\hline $\begin{array}{l}\text { July 1 to } \\
\text { September 30, } \\
\text { 2008 }\end{array}$ & 153 & 136 & 14 & 10.3 & 51 & 33.3 \\
\hline
\end{tabular}

From July 1 to December 31, 2007, a total of 328 GIC appointments were made. Of the 328 people appointed, 293 responded to the survey (89.3 percent).

${ }^{362}$ See supra note 357.

${ }^{363}$ The GIC Reports, supra note 361 at 2. 
Of that number, 16 appointees were visible minorities, which amounts to 5.5 percent. To provide a basis for comparison, the number of women GIC appointees for the same period was 105 , or 32 percent.

From January 1 to June 30, 2008, 460 individuals were appointed and 104 individuals were reappointed, for a total of 564 appointees. Of that number, 473 responded to the survey of employment equity data (83.9 percent). Of the 473 who responded, 28 (5.9 percent) self-identified as visible minorities. The percentage of appointees who were women was 31.4 percent.

From July 1 to September 30, 2008, 153 GIC appointments were made. 136 individuals (88.9 percent) participated in the survey. Fourteen, or 10.3 percent, were members of visible minorities. During that same time, one-third of the appointees were women.

Interestingly, the reports state that the workforce availability is 8.1 percent for visible minorities and 55.8 percent for women. ${ }^{364}$ The source for this data is not indicated. The 2006 census data puts workforce availability of visible minorities at 15.3 percent, ${ }^{365}$ which is much higher than the number used in the Reports. Even the 1996 census data (which is already over 10 years old) puts workforce availability of visible minorities at 10.3 percent. ${ }^{366}$ The difference is significant. For example, the proportion of GIC appointees from July to September 2008 who were visible minorities (10.3\%) would appear to exceed

\footnotetext{
364 Ibid. at 2.

${ }^{365}$ Employment Equity Data Report, supra note 359.

366 "Employment Equity Act Review: A Report to the Standing Committee on Human Resources Development and the Status of Persons with Disabilities" (December 2001) online:

$<$ http://www.hrsdc.gc.ca/eng//p/lo/lswe/we/review/report/toc.shtml. $>$ Workforce availability data at Appendix F online: <http://www.hrsdc.gc.ca/eng//p/lo/lswe/we/review/report/appendix_f.shtml\#f>. The workforce availability of women, according to the 1996 census was 46.4 percent.
} 
workforce availability data that the government is using, but would lag significantly behind 2006 census data. It is unclear which data the federal government is using to gauge the representativeness of appointments being made in 2007-2008. According to the notes on the GIC Reports, the population information used for linguistic representation and bilingualism is based on 2006 Census data. The population information used to measure regional representation is based on 2007 data from Statistics Canada. ${ }^{367}$

Although this information is somewhat enlightening, two further caveats are necessary with respect to the relevance of this data to the present analysis: (1) the numbers are for all GIC appointments and would thus include nonadjudicative agencies; and (2) as the reports track appointments and reappointments, they do not reflect the number of existing tribunal members who belong to designated groups. As a result, the reports do not reflect the current composition of federal appointees. In the absence of more specific data, however, this information is nonetheless a helpful starting point. The fact that the Privy Council Office surveys and reports the number of appointees belonging to designated employment equity groups (as well as their mother tongue and province of origin) seems to suggest that the current government maintains an interest in the representativeness of GIC appointments.

\section{The Representativeness of Tribunals in the Province of Ontario}

Although similar FOI requests were made to the Province of Ontario, the Ontario government does not currently maintain any information regarding the racial diversity of its adjudicators, nor with respect to public appointments

${ }^{367}$ GIC Reports, supra note 361 at $1-2$. 
generally. ${ }^{368}$ As a result, it is impossible to determine the number or proportion of adjudicators in the province who are members of racialized groups. ${ }^{369}$ In response to my FOI request, however, I was given the opportunity to interview Debra Roberts, Deputy Chief of Staff, Human Resources and Public Appointments. ${ }^{370}$ Ms. Roberts confirmed that there is no formal mechanism to collect data regarding the ethnic or racial origin of adjudicators or appointees. ${ }^{371}$ At the same time, Ms. Roberts stated that most tribunal Chairs have a sense of the diversity of their particular tribunal and would know if there was a gap in representation that they should aim to fill. ${ }^{372}$ According to Ms. Roberts, the Ontario government and the various tribunals recognize the importance of diversity. However, there is currently no plan to begin to collect data with respect to the racial origin of provincial adjudicators. ${ }^{373}$

\section{The Impact of the Presence of Racially-Diverse Adjudicators}

\section{The Human Rights Tribunal of Ontario - A Community of Judgment}

The main purpose of the interviews with adjudicators was to test the hypothesis that adjudicators from racialized groups, by bringing different perspectives to the tribunals, can have a beneficial impact upon administrative decision-making. The objective was not to determine whether racialized adjudicators decide cases in a certain way. As such, I have not attempted to

\footnotetext{
${ }^{368}$ Notes from an interview with Debra Roberts, dated April 20, 2009 [the "Roberts Interview," on file with author].

${ }^{369}$ Although biographical information is available online for most Ontario adjudicators, it would be highly imprecise to make assumptions about racial background solely on the basis of such information.

${ }^{370}$ Roberts Interview, supra note 368.

${ }^{371}$ The proportion of women appointees is available due to data collected for human resources purposes. Women account for 46 percent of full-time and 45 percent of part-time members. Ibid. 372 Ibid.

${ }^{373}$ Ibid.
} 
draw links between adjudicators and specific decisions. Rather, the theoretical arguments for diversity are based on the more nuanced view of the potential impact of racially diverse tribunals described in earlier sections of this thesis.

The only tribunal from which I had significant participation was the HRTO. The HRTO has a total of 22 full-time Vice-Chairs and 22 part-time members. The Chair and six full-time Vice-Chairs participated in interviews. According to the Chair, the proportion of full-time Vice-Chairs who are members of racialized groups is approximately 30 percent. ${ }^{374}$ Of the seven participants, four selfidentified as belonging to a racialized group. ${ }^{375}$

\section{a. Impact on Own Perspective}

The initial area of inquiry was the extent to which an adjudicator's racial background could impact their perspective on cases before them. ${ }^{376}$ All of the HRTO adjudicators, both racialized and non-racialized, acknowledged that an adjudicator's racial background could have an impact on their perspective on a particular case. ${ }^{377}$ At a general level, a number of HRTO adjudicators recognized that everyone, including themselves, is a product of the various experiences and influences to which they have been subject. ${ }^{378}$ One participant remarked that "everyone comes with a perspective" ${ }^{379}$ while another stated that

\footnotetext{
${ }^{374}$ As neither the provincial government nor the HRTO maintain statistics, this is based upon the Chair's personal knowledge of the racial origin of the adjudicators. Gottheil Interview.

${ }^{375} \mathrm{D}$ Interview, E Interview, F Interview, G Interview.

${ }^{376}$ A very high volume of human rights applications are resolved through mediation, which is conducted by HRTO members. In the context of mediation, awareness of and the ability to navigate cultural perceptions and practices might indeed take on greater importance. This was, however, beyond the scope of this inquiry.

${ }^{377}$ Gottheil Interview, B Interview, C Interview, D Interview, E Interview, F Interview, G Interview.

${ }^{378}$ B Interview, C Interview, D Interview, E Interview.

${ }^{379} \mathrm{~B}$ Interview.
} 
"no one is truly neutral." ${ }^{380}$ One participant responded that a person's background is the "lens" through which he/she sees the world. ${ }^{381}$ A couple of participants from racialized groups expressed the view that they felt that their experience provided them with some insight and sensitivity toward racism, discrimination and being subject to the assumptions of others. ${ }^{382}$ One participant said more specifically that allegations that would seem incredible to someone else might have a "ring of truth" to her, as a racialized person. ${ }^{383}$

At the same time, a common response was that race could have an impact on an adjudicator's perspective, as would a number of other characteristics, such as gender or socio-economic background. ${ }^{384}$ Many of the participants felt that race, along with various other influences and experiences in one's life, inevitably had an impact on how they would view situations.

Interestingly, the recognition that a person's perspective is shaped by their own unique experiences led a number of the participants to add that they make a conscious effort to recognize their own perspective and to either "shift" 385 that perspective or to "step outside" 386 of their own experience when hearing and deciding a case. ${ }^{387}$ For adjudicators from racialized groups, this includes knowing the limitations of their own perspective, and understanding that their

\footnotetext{
${ }^{380} \mathrm{D}$ Interview.

${ }^{381} \mathrm{G}$ Interview.

${ }^{382} \mathrm{E}$ Interview, F Interview.

${ }^{383} \mathrm{G}$ Interview.

${ }^{384} \mathrm{E}$ Interviews, F Interview.

${ }^{385} \mathrm{D}$ Interview.

${ }^{386}$ E Interview.

${ }^{387}$ B Interview, C Interview, D Interview, E Interview.
} 
experience is not the same as that of other individuals from racialized groups and from other equality-seeking groups, such as the disabled. ${ }^{388}$

Overall, the responses of the HRTO participants are consistent with the argument that judges and adjudicators from racialized groups bring different perspectives to the task of adjudication, as discussed in Part II of this thesis. Given the above comments, it also appears that the participants would find unconvincing a view of impartiality as an absence of perspective. While some of the racialized participants were of the view that their backgrounds provided them with particular insights, they also understood the need to recognize their own particular perspectives.

\section{b. Impact on Perspectives of Fellow Adjudicators}

The HRTO participants were asked about whether they either sought or provided advice to their colleagues on issues that arose in the context of cases that they were hearing. All of the participants responded that they routinely discussed issues relevant to their work with colleagues in order to enhance their own understanding of such issues in general or with respect to particular cases. ${ }^{389}$ None of the participants reported having been confronted by a situation that they felt unfamiliar with or had difficulty understanding on the basis of the racial or ethnic origin of the applicant. Some participants stated that if faced with such a situation, they would consult a colleague with greater familiarity or expertise with respect to the particular issue, such as a cultural practice, if they

\footnotetext{
${ }^{388} \mathrm{~F}$ Interview.

${ }^{389}$ Gottheil Interview, B Interview, C Interview, D Interview, E Interview, F Interview, G Interview.
} 
felt it was outside their scope of knowledge.$^{390}$ A couple of participants reported consulting with colleagues on gender-related issues in order to obtain the viewpoint of someone of a different gender. ${ }^{391}$

The participants were asked to provide examples of situations in which their own perspectives were altered or affected by the input of their fellow ViceChairs. While most participants could not identify specific examples, they responded that because of the diversity of the tribunal and the issues that it deals with, there was a constant process of learning ${ }^{392}$ and "gaining insight into the perspectives of others." ${ }^{393}$ A few of the participants gave the specific example of the case described in Chapter II, Abdallah v. Thames District School Board, which gave rise to discussions among tribunal members about whether or not the impugned remarks constituted discrimination. ${ }^{394}$ The participants who mentioned the Abdallah case felt that it led to a frank and vigorous discussion about the issues raised in that case and challenged the views of some colleagues. ${ }^{395}$ When asked whether they had ever provided alternative views or explanations to their colleagues on issues with which they had greater familiarity, many participants responded that they had. ${ }^{396}$ Some examples include: the credibility of a witness who cried during testimony, where crying could be viewed differently in a particular culture; ${ }^{397}$ the implications of a dispute that arose within

\footnotetext{
${ }^{390}$ B Interview, F Interview.

${ }^{391} \mathrm{D}$ Interview, G Interview.

392 Gottheil Interview, B Interview.

${ }^{393} \mathrm{~F}$ Interview.

${ }^{394}$ See pages 62-64 above. Gottheil Interview, E Interview, F Interview, G Interview.

${ }^{395}$ Gottheil Interview, E Interview, F Interview, G Interview.

${ }^{396} \mathrm{~B}$ Interview, D Interview, E Interview, F Interview.

${ }^{397}$ B Interview.
} 
a particular religious community; ${ }^{398}$ the impact of an offensive remark on a racialized group; ${ }^{399}$ the difficulty that certain groups, such as persons with disabilities or the socio-economically disadvantaged, may have in meeting strict deadlines; ${ }^{400}$ and ethno-cultural reasons why an applicant would settle rather than pursue a meritorious claim. ${ }^{401}$

A couple of participants mentioned that they either informed themselves or obtained a better understanding of different situations by reading the decisions of their colleagues. ${ }^{402}$ Another process through which the participants benefit from the perspective and experience of their colleagues is the practice of circulating draft decisions for comment. ${ }^{403}$ Many of the adjudicators found this to be an invaluable practice that allowed them to benefit from the different perspectives and areas of expertise of their colleagues. ${ }^{404}$ It also provides an opportunity to ensure that the adjudicator considered alternative interpretations of the facts or other potential issues.

Many administrative tribunals have adopted some form of draft decision review. $^{405}$ Draft decisions are either circulated among tribunal members or reviewed by the Chair or the Chair's designate for the purposes of ensuring consistency in style, format and reasoning. ${ }^{406}$ It also ensures that the reasons

\footnotetext{
${ }^{398} \mathrm{D}$ Interview.

${ }^{399} \mathrm{E}$ Interview, F Interview.

${ }^{400} \mathrm{C}$ Interview.

${ }^{401} \mathrm{E}$ Interview.

402 Gottheil Interview, B Interview, F Interview.

${ }^{403}$ Kevin Whitaker, Michael Gottheil, Michael Uhlmann, "Consistency in Tribunal Decision Making: What Really Goes On Behind Closed Doors...” (unpublished) at 13.

${ }_{404}$ Gottheil Interview, B Interview, E Interview, F Interview.

${ }^{405}$ Whitaker et al., supra note 403 at 15 . The OLRB also has a process for circulating draft decisions. Whitaker Interview.

406 Ibid. at 15.
} 
properly explain the result and that where a decision might depart from the expected outcome, the tribunal as a whole has had the opportunity to consider the matter internally. ${ }^{407}$ The practice of commenting on draft decisions must be exercised with due care because it would be inconsistent with principles of natural justice if adjudicators who did not hear the case influence the final decision. In Consolidated Bathurst, supra, the Supreme Court considered the propriety of a full board meeting held by the OLRB to discuss a draft decision.

Gonthier J. writing for the majority stated:

The rules of natural justice should not discourage administrative bodies from taking advantage of the accumulated experience of its members. On the contrary, the rules of natural justice should in their application reconcile the characteristics and exigencies of decision making by specialized tribunals with the procedural rights of the parties. ${ }^{408}$

The HRTO, through its formal and informal processes and practices, provides an example of an administrative tribunal operating as a community of judgment. ${ }^{409}$ The atmosphere at the HRTO is one of collegiality ${ }^{410}$ in which fellow members share perspectives with each other through informal conversations and through more formal structures such as weekly meetings. One participant stated that the culture of the tribunal "supports interaction." ${ }^{111}$ By virtue of their diversity, the Vice-Chairs can exchange information with respect to

\footnotetext{
407 Ibid. at 14.

${ }^{408}$ Consolidated-Bathurst, supra note 108 at para. 30.

${ }^{409}$ Notwithstanding the absence of adjudicators from racialized groups, the practices of the OLRB support the potential for the development of a community of judgment and greater structural impartiality. Like the HRTO, members of the OLRB meet regularly, share draft decisions for comment and participate in electronic discussions of a variety of issues in order to share their knowledge and experience. Whitaker Interview.

${ }^{410}$ Gottheil Interview.

${ }^{411}$ B Interview.
} 
cultural practices and different contexts with which they have experience..$^{412}$

They each have their respective areas of experience and expertise and not only value but also draw upon that of their colleagues as a "resource." $"$ "13 The respect that the Vice-Chairs have for one another's expertise ensures that the tribunal is an "assembly of peers." ${ }^{\text {"14 }}$ Moreover, whether during meetings or through email exchanges, adjudicators communicate their viewpoints with one another, constantly "learning and broadening" 415 their perspectives, or, in Arendtian terms, cultivating an enlarged mentality. It should be noted that as full-time members of the HRTO, the participants have a greater opportunity to come into contact with one another informally to discuss issues. Because electronic exchanges are now commonplace, however, there is still ample opportunity for discussion with colleagues who work part time or who are located outside of Toronto. ${ }^{416}$

The formal and informal interactions and practices of the HRTO effectively portray how structural impartiality could be achieved in practice. By consulting with colleagues and seeking their input, the adjudicators routinely challenge their own assumptions and go beyond their own personal perspectives, thus expanding their knowledge and awareness. The circulation of a draft decision would provide an additional opportunity to challenge hidden assumptions. For example, an adjudicator could be asked by another adjudicator why he/she found

\footnotetext{
${ }^{412}$ Of course, such information must be addressed appropriately as individual cases must be judged on the basis of the evidence that was adduced during the hearing and all of the participants were conscious of that limitation.

${ }_{413}$ Gottheil Interview.

414 Crépeau \& Nakache, supra note 143 at 58.

${ }^{415}$ Gottheil Interview.

${ }^{416}$ Whitaker et al., supra note 403 at 13.
} 
a particular witness credible and would be required to articulate the assumptions upon which the finding was based. A fellow adjudicator could then provide an alternative interpretation. ${ }^{417}$ This lessens the likelihood that a certain perspective dominates the decisions of the HRTO and thus enhances the impartiality and decision-making capability of the tribunal. Finally, the composition of the HRTO, which includes approximately 30 percent of full-time Vice Chairs from racialized groups, means that there is a critical mass to ensure that racialized perspectives can be expressed freely and that a robust exchange can take place.

The HRTO and its adjudicators provide an especially propitious example of how a community of judgment would function. It is the expert tribunal dealing with issues of human rights and discrimination and its adjudicators were selected on the basis of their expertise. ${ }^{418}$ They are especially attuned to issues of cultural sensitivity, disadvantage and the pitfalls of stereotyping. The responses to the interview questions are thus not surprising. As is evident from the above, the HRTO participants exhibited a great deal of openness toward the possibility that racialized adjudicators would provide different and important perspectives to the adjudication of human rights cases. They were also more mindful of the potential limitations on their own ability to understand situations or circumstances outside of their own experience. Finally, as participation was voluntary, it is possible that the adjudicators who volunteered to participate in this study are

\footnotetext{
${ }^{417}$ One frequently cited example is the failure of a witness to make eye contact. While a common assumption is that the person is dishonest, this could also be due to other factors, such as deference or respect that are based in cultural differences.

${ }^{418}$ Gottheil Interview.
} 
already open to the value of diversity and greater representation of racialized groups on administrative tribunals.

\section{c. Perceived Impact on Litigants}

The third area of inquiry was whether the racial background of the adjudicators had any perceived impact on the litigants who appeared before them. A couple of HRTO participants from racialized groups noted that when racialized litigants saw that they would be appearing before them, they appeared to become more comfortable or relaxed. ${ }^{419}$ As those participants noted, however, it was impossible to discern whether or not the litigant's response was a reaction to the adjudicator's racial background, as opposed to other factors such as gender, demeanour, or manner. ${ }^{420}$ One participant stated, however, that in a couple of race-related cases that she had heard, she perceived that the applicants were more comfortable in describing the discriminatory incidents to her. She felt that they were more confident that, as a racialized person, she would be able to understand them. ${ }^{421}$ Two non-racialized participants responded that they assume that their racial background has an impact on litigants. ${ }^{422}$ One participant responded that she has felt a racialized litigant's initial reservations dissipate. ${ }^{423}$ Another participant stated that he felt that it is likely that he is perceived as "part of the system" and makes efforts to establish trust by

\footnotetext{
${ }^{419}$ E Interview, F Interview, G Interview.

${ }^{420} \mathrm{E}$ Interview, $\mathrm{F}$ Interview.

${ }^{421} \mathrm{G}$ Interview.

${ }^{422}$ B Interview, C Interview.

${ }^{423} \mathrm{C}$ Interview.
} 
signalling respect, exercising sensitivity, and explaining the process to ensure that the individual fully understands the proceedings. ${ }^{424}$

While these responses are enlightening, the area of inquiry is extremely limited because the participants could only glean how they were perceived from the reactions or statements of the individuals appearing before them. Moreover, as each participant could only observe the litigants when they appeared before him/her, they had no basis for comparing how the litigant would have reacted to a different adjudicator.

\section{d. Summary}

As noted above, the HRTO is the expert tribunal on issues of human rights and discrimination. It is thus not surprising that it is racially diverse and that its adjudicators would readily see the importance of incorporating diverse views and understandings of the world into their decision-making. This inclination may not be as strong for adjudicators who are not from the human rights field. Therefore, while the HRTO provides a good example of how a community of judgment would function effectively, it cannot be seen as the norm. As the only tribunal from which I obtained significant participation, however, there is no basis for comparison. It would be enlightening to obtain information from other tribunals about their experiences with racial diversity. It would also be interesting to see to what extent the practices of the HRTO with respect to sharing draft decisions are common among different tribunals. Finally, it is also likely that through organizations such as SOAR and CCAT, administrative adjudicators from

${ }^{424}$ B Interview. 
different tribunals come into contact and interact with one another. This would be another potential opportunity for the exchange of perspectives and experiences. $^{425}$

\section{Interviews with Legal Clinic Lawyers}

As noted in the methodology section, in order to gain insight into the potential impact of racialized adjudicators on racialized tribunal users, I sought to interview legal clinic lawyers both at community legal clinics and legal clinics that serve particular ethnic groups. Legal clinic lawyers appear regularly before the kind of tribunals that are the subject of this analysis and represent a significant number of clients from racialized backgrounds, due to the demographics of the populations that they serve.

Due to the small number of participants, it is difficult to draw any generalized conclusions with respect to the effect of racialized adjudicators on litigants. The following is thus intended to summarize the responses that I received and not as a statement of findings or conclusions. Moreover, as previously noted, interviewing legal clinic lawyers provides a less precise assessment of the experience of racialized individuals who appear before administrative tribunals because clinic lawyers will view the proceedings as advocates and not as litigants whose interests are at stake in the proceedings. I nonetheless felt that this would be a worthwhile area of inquiry to add further dimension to the analysis.

\footnotetext{
${ }^{425}$ Indeed, the theme of CCAT's 2008 conference was "Serving a Diverse Population." Online: Canadian Council of Administrative Tribunals <http://www.ccatctac.org/en/conferences/docs/2008 Conference program En.doc.>
} 
The legal clinic lawyers who were interviewed had appeared, collectively, before the Landlord Tenant Board, the Social Benefits Tribunal, the Human Rights Tribunal of Ontario and the Immigration and Refugee Board. Certain participants had also appeared before the Pension Appeals Board and Employment Insurance Boards of Referees. Each of the participants appears before those boards at least a few times a year and before some tribunals more than others. Some participants appear before certain tribunals, such as the LTB, almost weekly. ${ }^{426}$

On the whole, the participants noted that they appeared relatively infrequently before racialized adjudicators as compared to non-racialized adjudicators. ${ }^{427}$ According to the participants, the tribunal that they appeared before that they found the most racially diverse was the IRB, ${ }^{428}$ which is consistent with the statistics obtained with respect to the percentage of visible minorities on the IRB.

The main areas of inquiry were: the level of satisfaction among clients from racialized groups; any perceptions of fairness or bias with the proceedings; and any experiences of discrimination or other adverse treatment. I also inquired about the barriers faced by clients of legal clinics from racialized groups, as compared to those faced by non-racialized clients. Where possible, the clinic lawyers were asked to compare the experience of their clients who were from

\footnotetext{
${ }^{426}$ Notes of interview with L, a lawyer from the KBCLS (“L Interview") dated April 9, 2009 (on file with author), Notes of interview with M, a lawyer from KBCLS ("K Interview") dated April 9, 2009 (on file with author), Notes of interview with N, a lawyer from SALCO ("N Interview") dated April 30, 2009 (on file with author), Notes of interview with P, a lawyer from SALCO ("M Interview") dated April 30, 2009 (on file with author), Notes of interview with Q, a lawyer from MTCSALC ("N Interview") dated April 23, 2009.

${ }^{427}$ L Interview, M Interview, N Interview, P Interview, Q Interview.

${ }^{428} \mathrm{~N}$ Interview, $\mathrm{P}$ Interview, Q Interview.
} 
racialized groups with those of clients from non-racialized groups. The participants were also asked to compare their experiences before adjudicators from racialized groups with those before adjudicators from non-racialized groups.

Because the clientele of MTCSALC is Chinese and Southeast Asian and the clientele of SALCO is South Asian, the lawyers who were interviewed from those clinics could not compare the experience of racialized, as opposed to nonracialized clients, before the tribunals. The other clinic that participated in the study, the KBCLS, is located in downtown Toronto and serves a highly diverse population. One KBCLS participant estimated that based on the intake forms and her own observations, approximately 30-40 percent of the clients were from racialized groups. ${ }^{429}$

\section{a. Barriers Faced by Clients}

The participants responded that the main barrier that their clients, both racialized and non-racialized, faced was communication. ${ }^{430}$ This included both language barriers and difficulty understanding the proceedings even when language was not an issue. ${ }^{431}$ With respect to language, clients had difficulty understanding written materials, such as communications from the tribunal, and also had difficulty when attempting to contact the tribunal by telephone. ${ }^{432}$ Moreover, the quality of the interpreters that were provided by the tribunals at hearings varied widely depending upon the tribunal. One participant responded that interpreters provided by the IRB, HRTO and WSIAT were generally good,

\footnotetext{
${ }^{429} \mathrm{~L}$ Interview. While the KBCLS's intake sheet contains a question regarding the client's country of origin, it is often left incomplete.

${ }_{430} \mathrm{~L}$ Interview, M Interview, N Interview, Q Interview.

${ }^{431} \mathrm{~L}$ Interview, M Interview.

${ }^{432} \mathrm{Q}$ Interview.
} 
while those provided by the SBT were not as good. ${ }^{433}$ Where technical terms were relevant, such as medical evidence before the SBT, one participant felt that the interpreters were lacking in the requisite expertise. ${ }^{434}$ Another respondent described an incident in which an interpreter was not available for a hearing, but the adjudicator refused to grant an adjournment. ${ }^{435}$

The participants reported that their clients, when testifying in the proceedings, have a great deal of difficulty conveying the facts in the manner that is preferred by adjudicators, that is, clearly, concisely and referring only to relevant facts. ${ }^{436}$ Due to differences in education and training, some participants felt that adjudicators failed to imagine and understand the difficulty faced by clients when expressing simple things or answering questions. ${ }^{437}$ The issue of communication is one that is not unique to individuals from racialized groups. The KBCLS participants felt that income and education level also negatively impacted their non-racialized clients' ability to present their cases. Issues of mental illness, physical disability and substance abuse were also raised. ${ }^{438}$

The participants felt that their clients' success depended upon their "likeability." 399 One legal clinic lawyer referred to a need to "make- over" clients to make them presentable to the tribunal in their appearance and manner of speech. ${ }^{440}$ Other lawyers referred to difficulties arising from "cultural interpretation" which includes intangible qualities such as accent, body language,

\footnotetext{
${ }^{433} \mathrm{Q}$ Interview.

${ }^{434} \mathrm{Q}$ Interview.

${ }^{435} \mathrm{M}$ Interview.

${ }^{436} \mathrm{~L}$ Interview, Q Interview.

${ }^{437}$ L Interview, M Interview, Q Interview.

${ }^{438} \mathrm{~L}$ Interview, M Interview.

${ }^{439} \mathrm{~N}$ Interview, Q Interview.

${ }^{440} \mathrm{Q}$ Interview.
} 
eye contact, and manner of speech that they felt nonetheless impacted the adjudicator's assessment of their client's credibility and therefore on their success. ${ }^{441}$

\section{b. Differential Treatment of Racialized Clients}

When asked about specific incidents of differential treatment or bias exhibited by tribunal members, whether from racialized or non-racialized groups, toward racialized clients, most of the clinic lawyers had not experienced any direct, offensive conduct. ${ }^{442}$ A couple of incidents of inappropriate conduct on the part of adjudicators were, however, described. For example, one participant referred to an incident in which an adjudicator from the SBT mocked the accent of a racialized client. ${ }^{443}$ She also reported having to "translate" her client's English because, although she had no difficulty understanding the client, the SBT adjudicator repeatedly claimed that he could not understand the client because of his accent. ${ }^{444}$ Another clinic lawyer recalled a hearing before the IRB during which the adjudicator chastised a racialized client for smiling during the proceedings. ${ }^{445}$ On the other hand, one participant reported that an LTB adjudicator reacted harshly to a racist comment made by a landlord who was testifying in a proceeding. ${ }^{446}$

While overt, discriminatory conduct is rare, a couple of participants felt that some IRB adjudicators that they had appeared before maintained stereotyped

\footnotetext{
${ }^{441} \mathrm{~N}$ Interview, P Interview, Q Interview.

${ }^{442}$ L Interview, M Interview, Q Interview.

${ }^{443} \mathrm{~N}$ Interview.

${ }^{444} \mathrm{~N}$ Interview.

${ }^{445} \mathrm{P}$ Interview.

${ }^{446} \mathrm{~L}$ Interview.
} 
assumptions about certain cultures. ${ }^{447}$ This issue arose in the context of, for example, arranged marriages. ${ }^{448}$ The SALCO participants also felt that there was an inherent bias in the sources relied upon by the IRB for country conditions, which were all Western, such as U.S. State Department reports. The adjudicators were more reluctant to accept news sources from within the country at issue because they were not familiar with them. ${ }^{449}$ Finally, a couple of participants expressed the view that they perceived biases on the basis of socioeconomic class. A KBCLS participant felt that there was a bias against "lowincome" individuals, who she perceived had to work harder to establish credibility before the LTB. ${ }^{450}$ Similarly, a SALCO participant expressed the view that some SBT adjudicators exhibited a bias against welfare recipients, such as an assumption that they are lying. ${ }^{451}$

\section{c. Clients' Satisfaction and Perceptions of Fairness}

Another area of inquiry was the perceptions of fairness and the general satisfaction of racialized persons who appeared before the relevant administrative tribunals. With respect to satisfaction, the general sense was, not surprisingly, that clients were satisfied when they were successful. ${ }^{452}$ When unsuccessful, many clients, both racialized and non-racialized, felt a sense of dissatisfaction or unfairness because they did not have a full understanding of

\footnotetext{
${ }^{447} \mathrm{~N}$ Interview, P Interview.

${ }^{448} \mathrm{~N}$ Interview. The adjudicator did not accept that the marriage was bona fide because he did not find it credible that the individual, who was of South Asian origin, would marry a divorced woman.

${ }^{449} \mathrm{~N}$ Interview, P Interview.

${ }^{450} \mathrm{~L}$ Interview. She further noted that the bias she perceived against persons in poverty could be connected to racial bias.

${ }^{451} \mathrm{~N}$ Interview.

${ }^{452}$ L Interview, M Interview, N Interview, Q Interview.
} 
what happened. ${ }^{453}$ The SALCO participants responded that the experience of appearing before tribunals is not "empowering" for their clients. ${ }^{454}$

The issue of fairness is more difficult, because unless their clients specifically commented, the participants did not have a basis for assessing their clients' perception of the fairness of the proceedings. Moreover, the participants intimated that their clientele was unlikely to articulate their assessment of the proceedings in such a manner. ${ }^{455}$ A couple of anecdotal accounts were provided when asked about the experience of racialized litigants before administrative tribunals. For example, one participant stated that a black client expressed a concern about his likelihood of success when he saw that everyone in the hearing room, other than himself, was white. ${ }^{456}$

While a couple of participants mentioned that their clients were more comfortable with the non-courtroom settings of administrative proceedings, ${ }^{457}$ certain settings, such as immigration detention review, were found to be particularly intimidating for members of racialized groups. ${ }^{458}$ Although the clients might not have been able to identify these issues, some participants felt that the informality of administrative hearings acted to the detriment of their clients. ${ }^{459}$ One participant stated that LTB adjudicators "cut corners" and did not adhere to certain procedural rules, sometimes allowing counsel or paralegals representing landlords to give evidence or to make legal argument in the middle of the

\footnotetext{
${ }^{453} \mathrm{M}$ Interview, Q Interview.

${ }^{454} \mathrm{~N}$ Interview, $\mathrm{P}$ Interview.

${ }^{455} \mathrm{~L}$ Interview, N Interview, Q Interview.

${ }^{456} \mathrm{~L}$ Interview.

${ }^{457} \mathrm{~N}$ Interview, $\mathrm{P}$ Interview, Q Interview

${ }^{458} \mathrm{~N}$ Interview.

${ }^{459}$ L Interview, N Interview.
} 
evidence. ${ }^{460}$ Another issue that was raised was whether or not the proceedings were transcribed. A couple of participants observed that IRB adjudicators were more careful about procedural fairness requirements than tribunals whose proceedings are not transcribed, such as the SBT ${ }^{461}$ Finally, a SALCO participant noted that some clients felt they had not been heard as a result of poor or inadequate language interpretation. ${ }^{462}$

In addition, a couple of themes emerged from the responses to the interview questions. Some participants felt that adjudicators on certain tribunals, such as the $\mathrm{HRTO}^{463}$ and IRB, ${ }^{464}$ were more professional, attuned to procedural fairness requirements and careful to explain the tribunal's procedures. ${ }^{465}$ When adjudicators took the time to explain the proceedings, this was perceived by the participants to have a positive impact upon the clients' level of satisfaction and their perception of fairness. ${ }^{466}$

Adjudicators on other tribunals, such as the SBT and LTB, were perceived to be less inclined to take the time to explain procedures. ${ }^{467} \mathrm{~A}$ common theme that emerged with respect to those tribunals was that adjudicators were in a rush to get through as many cases as possible and that they were simply "pushing people through.." ${ }^{468}$ Many of the participants felt that because of the adjudicator's

\footnotetext{
${ }^{460} \mathrm{~L}$ Interview,

${ }^{461} \mathrm{~N}$ Interview, Q Interview.

${ }^{462} \mathrm{~N}$ Interview.

${ }^{463} \mathrm{P}$ Interview, $\mathrm{Q}$ Interview.

${ }^{464} \mathrm{Q}$ Interview

${ }^{465} \mathrm{P}$ Interview, $\mathrm{Q}$ Interview.

${ }^{466} \mathrm{Q}$ Interview, $\mathrm{N}$ Interview.

${ }^{467} \mathrm{~L}$ Interview, M Interview, $\mathrm{Q}$ Interview.

${ }^{468} \mathrm{M}$ Interview. See also $\mathrm{L}$ Interview, $\mathrm{Q}$ Interview.
} 
desire to proceed quickly, their clients felt that they had not been heard ${ }^{469}$ or that they did not understand what had happened. ${ }^{470}$ The result of the need to proceed quickly was impatience or abruptness toward clients, ${ }^{471}$ in the form of a general lack of courtesy ${ }^{472}$ or even "bullying" of clients. ${ }^{473}$ The participants felt that this impacted more strongly on individuals who had difficulty answering questions, whether due to language barriers, cultural differences or educational background. ${ }^{474}$ As a result, litigants from racialized groups might be more negatively impacted by certain tribunals' efforts to hear cases efficiently than individuals who are not from racialized groups. At the same time, individuals who have difficulty communicating because of factors unrelated to their racial or ethnic origin, such as education or income level or disability would have a similar experience. Another point of dissatisfaction with regard to the LTB was the adjournments that resulted from over-booking of hearings, where clients attended and were not heard at all. ${ }^{475}$

The responses to the interview questions were remarkably similar to the findings of the Genn Study in the U.K. In that study, individuals were interviewed before and after the hearing and after they received a decision. ${ }^{476}$ The most common complaints were that a panel member was not listening or taking the problem seriously, was asking questions that were perceived as biased or

\footnotetext{
${ }^{469} \mathrm{~L}$ Interview, Q Interview.

${ }^{470} \mathrm{M}$ Interview, N Interview, P Interview, Q Interview.

${ }^{471} \mathrm{Q}$ Interview.

${ }^{472} \mathrm{M}$ interview.

${ }^{473} \mathrm{~N}$ Interview.

${ }^{474} \mathrm{M}$ Interview, N Interview, Q Interview.

${ }^{475} \mathrm{~L}$ Interview, M Interview, Q Interview.

${ }^{476} 529$ users were interviewed before their hearings, 374 were interviewed after the hearing but before a decision and 295 were interviewed after they received a decision. Genn et al., supra note 115 at 1.
} 
hostile, or had appeared to have made up their minds. ${ }^{477}$ Delays and adjournments were also a source of complaint. ${ }^{478}$

In the Genn Study, when asked whether something had happened that was unfair, biased or showed a lack of respect, after the hearing but before the decision, approximately one-fifth of the respondents responded yes. ${ }^{479}$ When the Minority Ethnic users were asked whether they thought that what had happened could be attributed to their ethnicity, one-third attributed the unfairness to their ethnicity. ${ }^{480}$ The group that was least likely to have said that something unfair had occurred were Black users (11\%), while 19 percent of White users, 26 percent of South Asian users and 24 percent of "other" ethnic users said that something unfair had occurred. ${ }^{481}$

In post-decision interviews, all Minority Ethnic users were asked if they felt their ethnicity had affected the tribunal's decision in any way. Sixteen percent responded "yes" and 8 percent said they "didn't know." Among unsuccessful users from Minority Ethnic backgrounds, one-third said they thought the tribunal's decision had been influenced by ethnicity. ${ }^{482}$ In addition, Minority Ethnic users were more likely to say that they did not understand the reason for the decision. The percentages of users who said they did not understand the reasons for the

\footnotetext{
477 Ibid. at 213.

478 Ibid.

479 Ibid. at 212.

480 Ibid. at 215.

${ }^{481} \mathrm{Ibid}$. at 213. The Genn Study further disaggregated the ethnic origin of the respondents and found significant differences among certain ethnic groups. When disaggregated, the percentages that stated that something unfair had occurred are as follows: Black African (9\%), Black Caribbean (17\%), Pakistani (22\%), Indian (25\%), "other" ethnicity (mostly comprised of users from Iraq, Iran, Egypt and Lebanon) (29\%). Ibid. at 212.

48234 out of 101 unsuccessful Minority Ethnic users. Ibid. at 238.
} 
decision are as follows: White (12 percent), Black (20 percent), South Asian (25 percent), and other (33 percent). ${ }^{483}$

Because the users were interviewed before and after the hearing, and after the decision, the Genn Study highlights certain "associations" between users' experiences and perceptions of fairness. For example, users who felt uncomfortable during the hearing, that they had not been given a chance to say all that they wanted, that felt that the panel had not understood their case or listened to all sides equally or who found the hearing more formal than expected (in post-hearing interviews) were more likely to find some unfairness in the hearing. ${ }^{484}$ This suggests that participation impacts on overall perceptions of fairness. Similarly, the study found a significant association between observer assessments of the tribunal's courteousness toward users and users' perception of the tribunal's understanding of the case. In other words, when the panel was observed as less than courteous, the users were more likely to say that the panel had not understood their case or that they had not been listening. ${ }^{485}$ Because users who felt they had not been listened to or understood were more likely to perceive some unfairness in the hearing, the study suggests an association between courtesy and perceptions of fairness.

While the interviews of clinic lawyers were not sufficient to find any differences in perceptions of fairness on the basis of race, the Genn Study suggests that race or ethnicity could be perceived as a factor. Meanwhile, although not directly related to race, conduct that is not necessarily associated

\footnotetext{
483 Ibid. at 235-36.

484 Ibid. at 218.

485 Ibid. at 223.
} 
with procedural fairness, such as abruptness, lack of courtesy, and a failure to explain or to listen, impact litigants' perceptions of fairness.

\section{d. Before a Racialized Tribunal Member}

The interviews inquired into the same issues, that is, barriers, discrimination or offensive conduct and satisfaction and perceptions of fairness, with respect to the experience of legal clinic clients before racialized adjudicators. The participants reported that they appeared infrequently before adjudicators who are members of racialized groups and that when they appeared before a racialized adjudicator of a particular tribunal, it was often the same member. ${ }^{486}$ As a result, it was difficult for them to make general observations with respect to their own experience or that of their clients before adjudicators who are members of racialized groups.

A couple of examples, however, provide some insight into the potential impact of racialized adjudicators on litigants from racialized groups. One participant mentioned a case in which the client, who was a racialized person, was extremely nervous, fainted and had to be taken to the hospital when she appeared before a non-racialized member of the IRB. At a subsequent hearing, before an IRB adjudicator who was a member of a racialized group, she expressed feeling significantly more comfortable and was able to complete the hearing. ${ }^{487}$ Another example that was provided was a hearing of a refugee applicant who was of Tamil origin. The hearing was before a panel of three adjudicators, one of whom was of South Asian origin, while the others were non-

\footnotetext{
${ }^{486}$ L Interview, N Interview, P Interview.

${ }^{487} \mathrm{P}$ Interview.
} 
racialized. The participant found that the questions of the South Asian adjudicator were more relevant and reflected a better knowledge of the region, while the questions of one of the non-racialized adjudicator were very basic. ${ }^{488}$

One particularly interesting finding of the Genn Study is the impact of the presence of racialized adjudicators on perceptions of fairness among tribunal users. The tribunals observed in that study sat in panels of three, with the exception of one tribunal in which a tribunal chair sat alone 18 percent of the time. ${ }^{489}$ The study sought to ascertain whether the ethnic composition of the panel had any impact on perceptions of fairness among Minority Ethnic users. The percentage of Minority Ethnic users who said that something unfair occurred during the hearing was less with respect to mixed tribunals as opposed to allwhite tribunals. For Black users, 11 percent said that something unfair had occurred when the panel was all-white, while 7 percent did when the panel was mixed. For South Asian users, 32 percent said something unfair had occurred when the panel was all-white, while 23 percent did when the panel was mixed. For "other" ethnic users, one-third perceived unfairness when the panel was allwhite and none did when the panel was mixed. On the other hand, a higher percentage of White users were more likely to respond that something unfair had occurred when the panel was mixed (23 percent) as opposed to 16 percent when the panel was all-white. ${ }^{490}$

The Genn Study suggests that, in terms of perceptions of fairness, the effect of the presence of racialized adjudicators on administrative tribunals is not

\footnotetext{
${ }^{488} \mathrm{~N}$ Interview.

${ }^{489}$ Genn et al., supra note 115 at 223.

490 Ibid. at 227.
} 
negligible. The study thus proposes that "increasing the ethnic diversity of tribunal panels might have a positive effect on perceptions of fairness among Minority Ethnic tribunal users." 491

\section{e. Summary}

Notwithstanding the limited number of participants and the difficulty associated with interviewing clinic lawyers as opposed to the clients themselves, it is possible to highlight certain common themes. First, the satisfaction and perceptions of fairness among litigants was enhanced when adjudicators took the time to explain the proceedings. When litigants were rushed through the proceedings, they felt they had not been heard and did not fully understand what was going on. These observations were true for both racialized and nonracialized litigants. For litigants from racialized groups who face additional barriers such as language, however, the experience is amplified. Moreover, though only supported by a couple of anecdotal examples, individuals from racialized groups do, at the very least, notice and react to the racial background of the adjudicator hearing their case. While the interviews reveal the potential for the presence of racialized adjudicators to have a positive effect on the experience of racialized litigants, it is not possible on the basis of these interviews to make any further conclusions as to the impact of racialized adjudicators on perceptions of fairness. The Genn Study, however, suggests that the racial diversity of the tribunal could have an impact on perceptions of fairness among racialized groups. What is highlighted, however, is the

\footnotetext{
${ }^{491} \mathrm{Ibid}$. at 226. In interviews with 63 tribunal members, "a number of respondents" also mentioned that increasing the diversity of tribunal panels would give greater confidence to Minority Ethnic users at tribunal hearings and enhance the appearance of fairness. Ibid. at 321.
} 
overwhelming importance of the perception on the part of litigants of having been heard and of understanding the proceedings. These would seem to further reinforce the necessity for participation and justification that were highlighted in Baker, supra. 


\section{CHAPTER V - RECOMMENDATIONS}

In Chapters I and II of this thesis, I explored and critiqued the theoretical justifications for diversity on the judiciary and applied those arguments to administrative adjudicators. In Chapter III, I developed an integrative conception of diversity that focuses on the impact of diverse judges and adjudicators on the institutions to which they belong. Chapter IV examined the potential for diversity to have an impact on administrative decision-making at a practical level. In Chapter V, I will conclude my analysis with recommendations to attain greater diversity on adjudicative administrative tribunals and to reap the benefits of diversity.

\section{A. Implement Policies to Increase Diversity}

The website of the Public Appointments Secretariat (PAS) of the Ontario government contains the following statements under the heading "Principles Governing the Appointments Process":

Persons selected to serve must reflect the true face of Ontario in terms of diversity and regional representation; and

We must also ensure that these persons are representative of all segments of Ontario society. ${ }^{492}$

The federal government's website for information relating to GIC appointments contains no broad statements about diversity and representativeness. ${ }^{493}$ The federal government has, however, acknowledged the need for public appointments to reflect the Canadian population:

\footnotetext{
492 Public Appointments Secretariat, "General Information" online: Public Appointments Secretariat <http://www.pas.gov.on.ca/scripts/en/generallnfo.asp?\#4.>

${ }^{493}$ Government of Canada "Governor in Council Appointments" online:

<http://www.appointments-nominations.gc.ca/index.asp?lang=eng\&Page=index>
} 
Appointment recommendations take into consideration the desire to ensure that Governor-in-Council appointments reflect Canada's diversity, in terms of linguistic, regional and employment equity representation. ${ }^{49}$

As a result, in addition to the requests for statistics on current levels of representation, Access to Information and Freedom of Information requests were made to both the federal and Ontario government requesting documents relating to policies, initiatives or measures to increase the representation of racialized groups on administrative tribunals. ${ }^{495}$ Neither the federal government nor the Ontario government provided any documents in response to these requests. ${ }^{496}$

This is not to say that the federal and Ontario governments do nothing to promote or increase diversity on the administrative tribunals within their jurisdiction. (See below.) The absence of any policies, guidelines or measures, however, leaves the objective of increasing the representation of racialized and other marginalized groups in the hands of individuals such as the tribunal Chair, the Minister responsible for the tribunal, or those administering public appointments. It depends on those individuals finding diversity a worthy goal, and one that merits the additional time and effort that it will take to achieve. This may explain to some extent why certain tribunals are more representative than others. ${ }^{497}$

The lack of policies and measures may be based on an assumption that as more racialized persons attain higher education levels and enter into certain

\footnotetext{
${ }^{494}$ Government of Canada (2007): Accountable Government: A Guide to Ministers and Secretaries of State, Annex C Appointments (Ottawa: March 2007) at 57, online: Office of the Prime Minister <http://pm.gc.ca/eng/media. asp?id=687>.

${ }^{495}$ ATI Requests, supra note 343.

${ }^{496}$ Responses to ATI requests, on file with author; Roberts Interview.

${ }^{497}$ Compare, for example, the diversity of the HRTO with the lack of diversity of the OLRB (or federally, the IRB and the CHRT). This may have something to do with the subject matter expertise of the tribunal but cannot entirely be attributed to that.
} 
professions, current under-representation will rectify itself, a so-called "trickle-up" effect. ${ }^{498}$ It cannot, however, be assumed that this trickling-up will occur on its own. For example, a U.K. study of women and public appointments found that women face specific barriers that men do not. Women were less aware of the possibility of serving on national public bodies and were thus far less likely to apply; they tended to lack confidence in their capacity to perform the roles in question; and they were concerned with the ability to balance work and caring duties. ${ }^{499}$ The report concluded that more outreach efforts must be made in a way that would attract qualified women. Moreover, in advertisements for such positions, greater emphasis should be put on job skills traditionally associated with women, such as communication, as opposed to experience. The report further concluded that the selection process must be conducted by trained personnel, fairly and transparently. This was based on a finding that out of the 40 percent female applicants to one body, none were ever shortlisted in two years. ${ }^{500}$

The type of measures that should be adopted include greater attention to the appointment and selection process; recruitment and outreach efforts; and targetting, tracking and reporting on the representativeness of administrative adjudicators. This is not intended to be an exhaustive list of the measures that could or should be adopted to increase diversity on adjudicative administrative tribunals but should be seen only as a starting point.

\footnotetext{
${ }^{498}$ Dame Hale, "More Women Judges" supra note 13 at 492 (in the context of the judiciary).

${ }^{499}$ L. Barmes, "Public appointments and representativeness" [2002] P.L. 606 at 608-09.

500 Ibid. at 610.
} 


\section{Increase the Openness and Transparency of the Appointment Process}

The need to increase the diversity of administrative tribunals leads inevitably to the issue of how adjudicators are selected and appointed. The subject matter of administrative appointments has been discussed frequently, and an in-depth analysis of the appointments process is beyond the scope of this thesis. For the purposes of this analysis, I will limit myself to making a couple of recommendations that I believe would help increase the representation of racialized groups on administrative tribunals.

Of course, the starting point for recommendations to improve the public appointments system is generally greater openness and transparency. Historically, the application and selection processes for administrative tribunals have been opaque and political. ${ }^{501}$ Vacancies were not advertised broadly, the appointment process was unclear and it tended to benefit those with political connections. Indeed, appointments have traditionally been viewed as a way of rewarding loyal supporters. ${ }^{502}$ In their study of the refugee determination system, Crépeau and Nakache identified certain weaknesses in the appointment mechanism of the IRB and found through interviews with former board members that appointments were highly politicized. They note that as appointments to the IRB constituted 50 percent of full-time GIC appointments available to the government, there was significant pressure to appoint supporters. ${ }^{503}$ Although

\footnotetext{
${ }^{501}$ Administrative Justice Working Group, "Future of Administrative Justice" supra note 3 at 197. 502 Judith McCormack, "What We Talk About When We Talk About Merit (And Why It Isn't Enough)" Speaking Notes for the Future of Administrative Justice Conference (January 2008), at 1. See also, Wyman, supra note 99 at para. 10.

${ }^{503}$ Crépeau \& Nakache, supra note 143 at 59-60.
} 
the process was revised in March 2004 to ensure higher quality appointments through an open and transparent process, this did not entirely end partisan appointments. ${ }^{504}$

The openness of both the federal and Ontario appointments systems has improved significantly as both levels of government now make information with respect to vacancies available online. ${ }^{505}$ Information about available positions and the application process is readily accessible ${ }^{506}$ Since 2003 , the PAS has undertaken a number of other measures to increase transparency and improve the appointments process in general. This included enhancing the role of Chairs in the appointment process, implementing requirements that all full-time Chair and Vice-Chair positions be advertised, and requiring that all applications be submitted on-line through the PAS website. ${ }^{507}$

Open and standardized application processes are a welcome change from the closed, inaccessible processes of the past. As Judith McCormack, a former Chair of the OLRB, notes, it signals the government's policy of openness and inclusiveness and the desire to obtain a breadth of representation. It may even produce a more diverse pool of qualified applicants. ${ }^{508}$ However, accessibility alone does not necessarily ensure that applicants from historically excluded

\footnotetext{
${ }^{504} \mathrm{Ibid}$. at 63-64.

${ }^{505}$ The websites are at <http://www.appointments-nominations.gc.ca/lstAnns.asp?lang=eng> and <https://www.pas.gov.on.ca/scripts/en/advertPositions.asp.>

${ }^{506}$ Of course, accessibility is limited to those with access to a computer and the ability to navigate the websites.

507 Ontario Ministry of Government Services, News Release, "McGuinty government moves to strengthen key agencies" (29 June 29 2006) online: Ministry of Government Services <http://www.gov.on.ca/mgs/en/News/053356.html.> In addition, appointments are for a maximum of 10 years, with an initial term of two years, followed by reappointment for a term of three years and a subsequent reappointment for five years. Ibid.

${ }^{508}$ McCormack, supra note 502 at 2 . McCormack nonetheless criticizes such initiatives for reinforcing a culture of "amateurism" in which it appears that anyone can qualify for a tribunal position. Ibid. at 3.
} 
groups, such as racialized persons, will become aware of and apply to become adjudicators. McCormack argues that open-ended advertising does not necessarily lead to the range of diversity necessary and that "deliberate, active outreach processes" are necessary to overcome a variety of systemic barriers facing racialized groups and persons with disabilities. ${ }^{509}$

In the judicial context, for example, the OJAAC's Annual Report "acknowledges that it must increase its efforts to encourage qualified members of under-represented groups to apply for judicial positions." ${ }^{510}$ The fact that vacancies on the Ontario Court of Justice are advertised broadly does not necessarily ensure that diverse candidates will apply. As a result, when the objective is to increase the number of applications from racialized groups, outreach activities take on greater importance..$^{511}$ In 1990, the OJAAC asked the Attorney General of Ontario to write a letter to 1200 senior women lawyers asking them to consider applying for judicial office. This conscious and novel attempt to expand the recruitment pool produced a marked increase in applications from women. ${ }^{512}$ The Ontario government has also recognized that outreach is necessary to increase the number of appointments from underrepresented groups to administrative tribunals. According to Debra Roberts, the PAS meets with ethno-cultural and community organizations to increase

\footnotetext{
509 Ibid. at 3.

510 Ontario Judicial Appointments Advisory Committee, Annual Report for the Period from 1 January 2005 to 31 December 2005, (Toronto, January 2006) at 20 [“OJAAC Report"]. (This appears to be the most recent report that is available).

${ }^{511}$ The OJAAC Report notes that "[t]he Committee has firmly accepted outreach as one of its roles, and will continue to invite candidates from the various under-represented sections of the legal community to seek appointment." Ibid. at 19.

${ }^{512}$ Kate Malleson, "The New Judicial Appointments Commission in England and Wales" in Kate Malleson and Peter H. Russell, eds., Appointing Judges in an Age of Judicial Power (Toronto: University of Toronto Press, 2006).
} 
awareness and to encourage individuals to apply for public appointments. Ms. Roberts advised that Cabinet Ministers and the Premier also conduct outreach and talk about appointments when meeting with community organizations. ${ }^{513}$

\section{Redefine the Concept of Merit}

An examination of the appointments process often leads to the suggestion that appointments must be merit-based. This is difficult, if not impossible, to dispute. In order to further the goals of administrative justice, to the extent possible, appointments to adjudicative administrative tribunals must be based on merit rather than political affiliations or other extraneous factors. ${ }^{514}$ Merit is important to ensure that an adjudicator has the requisite degree of experience and expertise to hear and decide cases competently, but is also important to "create an atmosphere where the tribunal is an assembly of peers." ${ }^{515}$ When certain appointees to a tribunal are seen as incompetent, or have been appointed purely on the basis of political connections, this has a detrimental effect on the working environment. ${ }^{516}$ Political appointments would not assist in the creation of the kind of community of judgment in which robust exchanges can take place. The trust and mutual respect that are necessary for such dialogue would be missing. Another of the initiatives of the Ontario government was thus to develop merit-based criteria with the Chairs of the tribunals to ensure that qualified individuals are appointed. ${ }^{517}$

\footnotetext{
${ }^{513}$ Roberts Interview.

514 "The merit principle is the primary bulwark against politicization." Sossin, "Speaking Truth" supra note 92 at 55.

${ }^{515}$ Crépeau \& Nakache, supra note 143 at 58.

516 Ibid.

${ }^{517}$ Roberts Interview.
} 
Merit, however, is often automatically thrown up as a defence against arguments for greater diversity. As Dame Brenda Hale notes, "it is interesting how the word 'merit' only emerges when the appointment of women and other non-standard candidates is being discussed." ${ }^{518}$ This betrays an assumption that the two values are incompatible with one another: "[t]he implicit assumption is that different means worse. ${ }^{519}$ Not only is this assumption objectionable and without basis, it assumes that all current adjudicators were appointed on the basis of merit, when it was not so long ago that those positions were seen as rewards for political service or support. ${ }^{520}$

In addition, merit has traditionally been construed too restrictively. Not surprisingly, narrow conceptions of merit lead to appointments from a limited field of candidates with similar experiences that have conventionally been seen as valuable. Traditional understandings of merit impede the recognition of nontraditional measures of value, such as unpaid or part-time labour, which has historically disadvantaged women. ${ }^{521}$ In the Canadian context, education and experience outside of Canada might be another under-valued qualification. Moreover, merit could include an understanding of another perspective or a particular life experience. ${ }^{522}$ Barmes argues that "if we do not believe that diverse ways of living produce diverse skills and abilities, we are never going to entrust important decision-making power to groups composed of people from a

\footnotetext{
${ }^{518}$ Dame Hale, "More Women Judges" supra note 13 at 493.

${ }^{519}$ Dame Hale, "Appointment and Removal" supra note 91 at 8.

${ }^{520}$ Dame Brenda Hale, "More Women Judges" supra note 13 at 493 (Baroness Hale is referring to judicial appointments in the U.K., but the same can be said about appointments to tribunals in Canada.)

${ }_{521}$ Barmes supra note 499 at 613.

${ }^{522}$ Sossin, "Culture of Justice" supra note 2 at 374.
} 
diversity of backgrounds." ${ }^{523}$ Finally, merit should be interpreted to encompass the ability to exercise judgment in a pluralistic society.

In addition to merit, administrative adjudicators are appointed on the basis of their subject matter expertise. The HRTO is composed of experts in the area of human rights; OLRB adjudicators are individuals who have extensive experience in the area of labour law. Expertise should also include experience, knowledge and familiarity with the population that a particular tribunal serves. Merit and expertise should thus not be limited to, for example, the number of years in private practice. Given the increasing diversity of the Canadian population, especially in urban centres such as Toronto, expertise should also include cultural sensitivity and experience working with people from diverse backgrounds. In a study of the IRB by Crépeau and Nakache, the former IRB members that they interviewed suggested that hiring conditions include "some experience, if not expertise, in a culturally-different environment" ${ }^{\prime 524}$ or the ability to empathize and understand the perspective of a refugee claimant. While there was no formerly no such requirement to become a Board member, ${ }^{525}$ cultural sensitivity is now listed as one of nine "behavioural competencies" that are used as a basis for evaluating candidates for the Immigration Appeals Division and the Refugee Protection Division. ${ }^{526}$ This should not only be the case for tribunals

\footnotetext{
${ }^{523}$ Barmes, supra note 499 at 613.

${ }_{524}^{524}$ Crépeau \& Nakache, supra note 143 at 76.

${ }^{525} \mathrm{Ibid}$. at 77.

${ }^{526}$ Immigration and Refugee Board Governor in Council Appointments Competency Profile, (16 March 2004), online: Immigration and Refugee Board of Canada <http://www.irbcisr.gc.ca/Eng/brdcom/empl/memcom/Pages/cppc.aspx.> Cultural sensitivity is defined as "the ability to take into account the social and cultural conditions, norms and beliefs prevailing in claimants' milieu of origin in assessing the credibility or plausibility of their actions. This involves the ability to
} 
such as the IRB or human rights tribunals, who come into greater contact with individuals from diverse backgrounds, but also for all adjudicative tribunals because of the increasingly diverse populations that they serve. The broad discretion possessed by most administrative adjudicators justifies a cultural awareness component to the expertise required of prospective adjudicators. They must be able to understand the nuances of difference without simply resorting to stereotypes in order to exercise their discretion fairly and judiciously.

Dame Brenda Hale of the House of Lords also argues, with respect to the judiciary, that merit should be examined on a collective as well as individual level. The bench, she argues, is a collective and "there is nothing wrong in trying to get the collective balance right." ${ }^{\text {527 }}$ She argues that a candidate's contribution to the diversity of the court could be among the criteria for judging the merit of individuals. Dame Hale also observes that certain attempts to strike an appropriate balance, such as the requirement of two Scottish Law Lords and one from Northern Ireland, do not attract the same merit scrutiny as do attempts to achieve a more diverse bench. ${ }^{528}$ The same could be said for regional representation on the Supreme Court of Canada. The allocation, by convention, of a seat on the Supreme Court to a judge from the Atlantic provinces is not challenged with calls to appoint a more qualified candidate from Ontario. Proposals for an Aboriginal seat on the Supreme Court, however, are not without controversy.

question one's own cultural assumptions, a willingness to understand a perspective other than one's own, and a commitment to recognize diversity both between and within cultural groups." Ibid.

527 Dame Hale, "Appointment and Renewal" supra note 91 at 9.

528 Ibid. 
Redefining merit and "behavioural competencies" might in fact be where the prescriptive aspects of the different rationales for diversity diverge. If we accept only the institutional rationale for diversity, that is, to enhance the legitimacy of administrative tribunals, measures that aim at increasing the number of racialized adjudicators might be sufficient. If, however, we accept the individual rationale for diversity and the conviction that diversity will have a substantive impact, then we need to go further. This would involve reconceiving the concept of merit and adapting qualifications and criteria to include abilities and experience that would further the institution's ability to achieve structural impartiality. Moreover, if tribunal Chairs or public appointments administrators have in mind the collective expertise of the tribunal and the objective of creating a community of adjudicators with different areas of experience and expertise, they can incorporate these objectives into their appointments.

Indeed, the administrative context provides greater possibilities than the judiciary for achieving diversity and incorporating additional dimensions to merit and expertise requirements. This is because the field of individuals who can become judges is already limited by virtue of the fact that one must be a lawyer and have practiced for a minimum number of years in order to become a judge. On the other hand, for many tribunals, adjudicators do not necessarily have to be lawyers and can be drawn from very different areas of experience. In addition, a number of tribunals have part-time positions, which means that an adjudicator can be someone who also holds another job at the same time. Appointments to 
administrative tribunals have the flexibility to look more broadly at the kind of experience that should be considered relevant to the work of the tribunal.

\section{Track the Representativeness of Appointments}

Both the federal and Ontario governments appear to recognize that administrative tribunals should be representative of the people that they serve. It is thus somewhat surprising that the Ontario government does not collect information with respect to the racial or ethnic background of its adjudicators. ${ }^{529}$ Indeed, it is difficult to see how the representativeness of public appointments can be ensured if such information is not gathered and maintained. ${ }^{530}$ Without demographic information about the composition of administrative adjudicators, the above principles ring hollow.

By contrast, demographic information is collected from Ontario provincial court judges. The Annual Report for 2005 of the Ontario Judicial Appointments and Advisory Committee ${ }^{531}$ details the number of appointments from "representative groups" ${ }^{232}$ from January 1989 to December 2005. Out of 240 appointments during that time period, 81 (33.8 percent) were women, 16 (6.7 percent) were Francophone, 5 (2.0 percent) were First Nations, 16 (6.7 percent) were visible minority and none were persons with disabilities. ${ }^{533}$ The percentage of those representative groups in proportion to the population of Ontario is not

\footnotetext{
${ }^{529}$ Roberts Interview.

530 It is, for example, instructive to know that approximately 46 percent of full-time appointees are women, thus demonstrating that a very good (although not quite proportionate) representation of women on Ontario administrative tribunals.

${ }^{531}$ OJAAC Report, supra note 510 at 2-3. The percentage of those representative groups in proportion to the population of Ontario is not provided.

532 "Representative groups" are women, Francophone, First Nations, Visible Minority and Persons with Disabilities. Ibid.

${ }^{533}$ Ibid. at 3.
} 
provided, but the Report notes an "under-representation of women, visible, cultural, and racial minorities and persons with a disability." ${ }^{534}$ If this information is solicited from provincial court judges and collated by the OJAAC, it is difficult to justify why the Ontario government should not do the same for adjudicative administrative tribunals when, as it acknowledges:

Ontario's adjudicative agencies, such as the Human Rights Tribunal of Ontario and the Ontario Rental Housing Tribunal, resolve disputes for more people each year than the court system. Every year, they resolve more than 100,000 cases and are the face of government for many Ontario families and business. ${ }^{535}$

The lack of demographic data is problematic because it is impossible to determine whether or not the representation of racialized persons on Ontario administrative tribunals is at all proportionate to the population in the province. While it appears, from the Roberts Interview, that tribunal chairs have an idea as to the diversity of their members and attempt to fill any perceived gaps, ${ }^{536}$ this informal "eyeballing" method is insufficient. To the extent that diversity and representation are seen to impact an institution's legitimacy, the numbers should be available to the public. Simply put, "[i]f representativeness - or even diversity simpliciter - is the goal, without these numbers there is no accountability."

The tracking of representation would also show whether certain groups are better represented than others and whether certain tribunals are more representative than others. In addition, to the extent that a critical mass is necessary to ensure

${ }^{534} \mathrm{Ibid}$. at 10 . It should be noted that with respect to federally appointed judges, statistics are available for the number of women appointees but not for other designated groups. "Number of Federal Judges on the Bench as of July 1, 2009", online: Office of the Commissioner of Judicial Affairs <http://www.fja.gc.ca/appointments-nominations/judges-juges-eng.html>. Moreover, the information is exempt from freedom of information legislation. Lawrence, supra note 18 at 22.

${ }_{535}^{53}$ News Release, supra note 507.

${ }^{536}$ Roberts Interview.

${ }^{537}$ Lawrence, supra note 18 at 23 (speaking of judicial appointments). Lawrence cites s. 9(1) of the federal Employment Equity Act which requires federally regulated employers to keep records in order to identify and rectify underrepresentation. 
that the voices of racialized groups are not stifled, it is not possible to determine whether or not that "mass" has been achieved.

At the federal level, adjudicators and GIC appointees are asked to identify whether they belong to any designated groups. In the case of federal tribunals, it is thus possible to see that there is an under-representation of racialized groups on the CHRT and EIBOR, but not on the IRB. With respect to GIC appointments, information about representativeness is reported to the Prime Minister. As noted in Chapter IV, however, the use of inaccurate or dated workforce availability data diminishes the usefulness of those reports. Moreover, those numbers had to be obtained through an ATI request and are not publicized or readily accessible, for example, on the government website. As a result, public accountability is also lacking with respect to federal appointments.

In addition to the composition of appointments to administrative tribunals, it would be useful if both the federal and Ontario governments were to track the number of applications received from each of the under-represented groups. ${ }^{538}$ This would help determine whether some groups are simply not applying for appointment as adjudicators. The government would then be better able to target its efforts to increase applications, such as outreach initiatives with particular groups. The ability to calculate the number of appointments made as a proportion of applications from a particular groups would also be helpful to determine whether the selection process or criteria acts to disadvantage certain groups. Without any such information, it is difficult to identify the barriers or

\footnotetext{
${ }^{538}$ Admittedly, candidates from historically marginalized groups are often reluctant to provide information such as whether they are from a racialized group or have a disability because they are concerned that the information could be used to their detriment.
} 
difficulties faced by individuals from under-represented groups and infinitely more challenging to correct them.

Certain jurisdictions have begun to track numbers in an attempt to improve the representativeness of public appointments. For example, the City of Toronto requests that as part of the application process, applicants voluntarily self-identify whether or not they belong to a diversity group (on the basis of gender, age, race, disability status, sexual orientation. $)^{539}$ The City then compared the number of board members appointed in each group to their percentage of the population in Toronto (based on numbers from Statistics Canada). ${ }^{540}$ The analysis determined that appointments of women, youth and East and Southeast Asian groups were lower than their population representation. It was also found that those groups were not applying for positions, which then led to targetted recruitment efforts such as advertising in the ethnic press and the distribution of brochures at major gatherings of diverse communities. ${ }^{541}$ The total number of applicants increased from 515 in 2004 to 2006 to 1804 from 2007 to 2008 . The proportion of appointments of members of racialized groups increased from 22 percent to 31 percent. The proportion of women appointed also increased from 33 percent in the previous term to 49 percent in the current term. ${ }^{542}$

Another example is the United Kingdom government, which in June 2009 announced targets for improving diversity in its public appointments. By March

\footnotetext{
${ }^{539}$ Maytree Foundation, Diversity Matters: Changing the Face of Public Boards at 36-37, online: Maytree Foundation http://maytree.com/PDF Files/DiversityMatters.pdf.

540 Ibid.

541 Ibid.

${ }^{542}$ City of Toronto, News Release, "City's civic appointments reflect greater diversity" (28 November 2008), online: City of Toronto http://wx.toronto.ca/inter/it/newsrel.nsf/11476e3d3711f56e85256616006b891f/773fff01088571a9 8525750f007b0173? OpenDocument\&Highlight $=0,{ }^{*}$ diversity ${ }^{*}$.
} 
2011 , the aim is that 50 percent of all new appointments are to be women, 14 percent of all appointments are to be persons with disabilities and 11 percent are to be ethnic minorities, which is the proportion that those groups represent of the total U.K. population. ${ }^{543}$ These targets were included in an action plan that encompasses measures such as monitoring and publication of performance to increase transparency, outreach and awareness raising activities, sharing of best practices, and a mentoring program to work with high potential applicants. ${ }^{544}$

\section{Maintain a Database of Candidates From Racialized Groups}

One particularly promising initiative to increase the number of racialized persons on public boards is the DiverseCity onBoard project of the Maytree Foundation ("Maytree"). DiverseCity onBoard "matches highly qualified candidates from racially and ethnically diverse communities with governance positions in agencies, boards, commissions and non profit organizations across the GTA. ${ }^{545}$

Maytree initiated this project with the objective of strengthening public institutions by increasing the representation of persons from ethnic and racial

\footnotetext{
${ }^{543}$ U.K. Government Equalities Office, Fact Sheet "Diversity in Public Appointments: New Appointments 2008-09" (2009) online: Government Equalities Office <http://www.equalities.gov.uk/pdf/296514 PublicAppoint factsheet acc.pdf>. The current number of public appointees are were 33.3 percent women, 5 percent persons with disabilities and 5.7 percent ethnic minorities. U.K. Government Equalities Office, Fact Sheet, "Diversity in Public Appointments: Public Bodies 2008" (2009) online: Government Equalities Office http://www.equalities.gov.uk/pdf/13239\%20Public\%20appoint\%20factsheet\%204th.pdf.

${ }^{544}$ U.K. Government Equalities Office, "Public Appointments: Opening Doors - Increasing Diversity, A Cross-Government Action Plan" (June 2009), online: Government Equalities Office http://www.equalities.gov.uk/pdf/296514 GEO ActionPlan acc.pdf.

${ }^{545}$ See Maytree "DiverseCity on Board" online: Maytree Foundation $<$ http://www.maytree.com/divcity/onboard/>.
} 
communities. ${ }^{546}$ In connection with this project, Maytree maintains a database of candidates from "Aboriginal, visible minority and under-represented immigrant communities." ${ }^{547}$ Vacancies on public boards are also listed on the website. Organizations looking to fill board positions can search the database for a suitable candidate. The database is also capable of "matching" candidates to vacancies. To date, Maytree has facilitated over 200 matches. ${ }^{548}$ A review of the list of appointments indicates that Maytree has facilitated a number of appointments to adjudicative agencies in Ontario. ${ }^{549}$ According to Debra Roberts, the PAS is in regular contact with Maytree and when a particular vacancy exists, the PAS will draw upon Maytree's database of candidates to determine whether there is a candidate who could potentially fill the position. ${ }^{550}$

The Maytree database is an important and innovative initiative because it helps respond to the so-called "pool problem" that is commonly raised in response to calls for greater diversity, whether on the judiciary or on tribunals. The pool problem claims that there are simply not enough qualified persons from racialized backgrounds to fill the positions. ${ }^{551}$ Persons from racialized groups have criticized this argument on the basis that it serves mainly to conceal other systemic barriers faced by marginalized groups, such as lack of access to influential networks. Moreover, to the extent that there might not be a large pool

\footnotetext{
${ }^{546}$ Maytree Foundation, "DiverseCity, the Greater Toronto Leadership Project" (pamphlet), online: Maytree Foundation <http://www. diversecitytoronto.ca/wpcontent/themes/openair/download/diversity brochure main.pdf $>$.

${ }^{547}$ Maytree Foundation, "About DiverseCity onBoard", online: Maytree Foundation <http://www.maytree.com/divcity/onboard/about-diversecity-onboard>.

${ }^{548}$ Ibid.

${ }^{549}$ Maytree Foundation, "Appointments", online: Maytree Foundation <http://www.maytree.com/divcity/onboard/appointments>.

${ }^{550}$ Roberts Interview.

${ }^{551}$ Devlin et al. supra note 75 at 810 (describing the pool problem in the context of the judiciary.)
} 
of qualified, racialized candidates, this too is symptomatic of barriers to obtaining the necessary qualifications, such as a law degree.

Centralizing the availability of this information as Maytree has done benefits both the candidates and the boards and agencies. The database brings to the forefront a complement of candidates that might not otherwise have come to the attention of the PAS and makes it easier for boards and agencies committed to diversity to find qualified candidates from under-represented groups. In addition, candidates also have a resource to refer to when looking for a position. The fact that the government makes use of the Maytree database is a positive step to increasing the representation of racialized persons on administrative tribunals.

The DiverseCity onBoard project is, however, limited to the greater Toronto area. In addition, there is no equivalent at the federal level. Given that the initiative relies largely upon information that is submitted and made available online, it would be possible to establish similar databases for broader use across the province and the country. Such databases would be a pragmatic and effective way of increasing the diversity of administrative tribunals, especially if the initiative is accompanied with efforts to raise awareness and encourage racialized persons to submit their names. Of course, governments would have to be committed enough to diversity to refer to the database when seeking to fill administrative vacancies. 


\section{B. Diversity Beyond Numbers: Fairness}

\section{Foster a Vibrant Community of Judgment}

Other than the redefinition of merit, the above recommendations are generally directed toward increasing the number of administrative adjudicators from under-represented groups such as racialized persons. If calls for greater diversity on administrative tribunals are based entirely upon the institutional rationale, then measures to obtain diversity need go no further. While implementing policies to increase the number of adjudicators from racialized groups could rectify existing imbalances and the institutional biases that this might give rise to, such policies alone would not be sufficient to reap the benefits of greater diversity.

An essential co-requisite to efforts to attain greater diversity is to challenge long-held notions about diversity and difference. Diversity on a formal level must be accompanied by a recognition that difference is not intrinsic in the other person, but rather the product of comparison. ${ }^{552}$ This essential step involves, as many of the HRTO participants noted, looking at our own stereotypes, categories for organizing the world, and attitudes toward people we treat as different. ${ }^{553}$ If the presence of racialized adjudicators is to have an impact on administrative tribunals, there must be an openness to such impact and a willingness to relinquish long-held beliefs, including about what it means to be impartial. "Diversity is not about letting people in but about letting go." 554

\footnotetext{
${ }_{552}^{52}$ Martha Minow, "Justice Engendered" supra note 67 at 13.

553 Ibid. at 79.

${ }^{554}$ Rackley, supra note 12 at 87.
} 
The working environment of administrative tribunals must value the diverse experiences and perspectives of their members and support their contributions. Furthermore, they must communicate that value. Adjudicators from racialized groups must feel that they are able to raise alternative perspectives freely and that they have the respect of their colleagues. The U.K. study of women and public appointments concluded that wholesale culture change was necessary in order to overcome barriers in the workplace, such as the persistence of informal networks that exclude women, unease with women in authority, and attitudes that women are not expected or encouraged to succeed. ${ }^{555}$

As argued above, a critical mass is one way to ensure that alternative perspectives can be voiced without hesitation. In addition, incorporating elements of experience and cultural sensitivity in merit criteria will help send the message that those qualities are valuable to the work of the tribunal, and that racialized adjudicators are not simply token appointments made to attain a superficial diversity. This is important to the creation of Crépeau and Nakache's concept of a "critical space," or an assembly of peers characterized by collegiality and mutual respect. Token appointments in order to achieve numerical diversity would be as damaging to that critical space as political appointments were to the functioning of the IRB. Diversity must be accompanied by the goal of creating of a community of judgment that allows for robust dialogue and debate among adjudicators. The HRTO, due to its diversity, collegiality, and the openness and

${ }^{555}$ Barmes, supra note 499 at 611. 
respect its members have for one another's expertise, provides an example of how this might be achieved in practice.

In addition to the working environment and culture, increased opportunity for interaction and interchange among tribunal members, such as full board meetings and the circulation of draft decisions, further ensures that the diverse expertise of different tribunal members could be benefitted from. Because of the availability of electronic means of discussion, the distance between tribunal members and the fact that some tribunal members work part-time need not be an impediment to such dialogue. As noted by the Chairs of the HRTO and OLRB:

The importance of fostering opportunities for the ongoing and casual interaction between adjudicators cannot be over-emphasized. Successful internal tribunal cultures foster open environments where all adjudicators are free to express opinions on issues of process, law and policy but at the same time permit those who hear individual cases to freely decide them according to their own judgment. ${ }^{556}$

An open environment characterized by collegiality enables a tribunal, once it is more diverse, the fully reap the benefits of that diversity.

\section{CONCLUSION}

Diversity requires that we think about the composition of public institutions in the pluralistic democracy in which we live. We must also think about why the composition of courts and tribunals matters. The institutional and individual rationales for diversity provide incomplete answers to that question. In this thesis, I have proposed an integrative conception of diversity that fills some of the gaps. Diversity is ultimately about fairness and justice. Because the value of participation and justification to the fairness of the administrative justice system

${ }^{556}$ Whitaker et al., supra note 403 at 14. 
has been firmly entrenched, it provides a particularly receptive context for diversity to have a real impact. The interviews with adjudicators and legal clinic lawyers shed some light on how this impact could occur in practice. Further empirical research, similar to the Genn Study in the U.K., would provide a clearer picture of the representativeness of administrative tribunals in Canada and would enable us to delve more deeply into questions such as the perception of fairness among individuals who appear before the tribunals. Given the importance of inclusion, equality and respect for diversity and inclusion in our increasingly diverse society, this would be a worthwhile endeavour. 